\title{
Hamsa
}

Journal of Judaic and Islamic Studies

$7 \mid 2021$

Visibility of Religious Difference in Medieval Europe and the Mediterranean

\section{Para lá dos túmulos e da herança patronímica: práticas judaicas nas ilhas Cabo Verde}

\section{Zelinda Cohen}

\section{(2) OpenEdition \\ Journals}

Edição electrónica

URL: https://journals.openedition.org/hamsa/1345

DOI: $10.4000 /$ hamsa. 1345

ISSN: 2183-2633

Editora

CIDEHUS - Centro Interdisciplinar de História Culturas e Sociedades da Universidade de Évora

Refêrencia eletrónica

Zelinda Cohen, «Para lá dos túmulos e da herança patronímica: práticas judaicas nas ilhas Cabo Verde», Hamsa [Online], 7 | 2021, posto online no dia 06 setembro 2021, consultado o 08 novembro 2021. URL: http://journals.openedition.org/hamsa/1345 ; DOI: https://doi.org/10.4000/hamsa.1345

Este documento foi criado de forma automática no dia 8 novembro 2021.

\section{cc) () $९$}

Hamsa est mise à disposition selon les termes de la Licence Creative Commons Attribution - Pas d'Utilisation Commerciale - Pas de Modification 4.0 International. 


\section{Para lá dos túmulos e da herança patronímica: práticas judaicas nas ilhas Cabo Verde}

\section{Zelinda Cohen}

\section{NOTA DO AUTOR}

Apoio da Fundação Calouste Gulbenkian

"ter uma sinagoga, um açougue kosher e finalmente um cemitério próprio"1.

\section{Introdução}

1 Vinham, como se sabe, de Marrocos e Gibraltar, mas também de Portugal, nomeadamente de Lisboa e do Algarve. Um ou outro da Argélia ou de Espanha e, mais residualmente, de outras paragens ${ }^{2}$. Nos túmulos que cá erigiram - todos eles horizontais ${ }^{3}$, simples, uniformes ${ }^{4}$ e obedecendo à mesma "forma geométrica composta por um trapézio encimado por um semicírculo na cabeceira" ${ }^{-}$, se encontram sepultados antepassados de famílias com descendentes que permaneceram em Cabo Verde e de outras sobre as quais só ficou a memória de terem algum dia vivido nestas ilhas.

2 A lista desses hebreus já foi elaborada pelas historiadoras Cláudia Correia ${ }^{6}$ e Ângela Benoliel Coutinho ${ }^{7}$ mas talvez seja importante assentar aqui os apelidos, acrescentando um ou outro, para situar o universo em exame:

\begin{tabular}{|l|l|l|}
\hline 1.Abecassis & 2.Abitbol & 3.Abohbot \\
\hline 4.Afflaló & 5.Alves & 6.Amzalak \\
\hline
\end{tabular}




\begin{tabular}{|c|c|c|}
\hline 7.Anahory & 8.Athias & 9.Auday \\
\hline 10.Azancot & 11.Azaniel & 12Azevey \\
\hline 13.Azulay & 14.Benahim & 15.Benara \\
\hline 16.Benatar & 17.Benazon (Benazou) & 18.Benchimol \\
\hline 19.Bendaham & 20.Bendavid & 21.Benefraim \\
\hline 22.Benoliel & 23.Benrós & 24.Levy Bentubo \\
\hline 25. Benunas (Bedunas) & 26.Boaruna & 27.Bodana \\
\hline 28.Bohana (Bouanaz) & 29.Brigham & 30.Buzaglo \\
\hline 31.Cagy & 32.Cardoso & 33.Cohen \\
\hline 34.Elasry & 35.El Baz & 36. Elasry \\
\hline 37.Elcaim & 38.Ezaguy & 39.Eznaty \\
\hline 40.Gabay & 41.Ismini & 42.Izaqui \\
\hline 43.Lasene & 44.Lassarini & 45.Levy \\
\hline 46.Malka & 47.Maman & 48.Mor José \\
\hline 49.Naury & 50.Niune & 51.Pairmy \\
\hline 52.Pimenta & 53.Pinto & 54.Ruah \\
\hline 55. Sabbat & 56.Seruya & 57.Tarregano \\
\hline 58.Urbin & 59. Wahnon & 60. Zafrany \\
\hline 61. Zagury & & \\
\hline
\end{tabular}

3 Não obstante o avanço alcançado com os estudos dessas duas investigadoras, há um aspecto na história dos hebreus em Cabo Verde que, a nosso ver, não tem sido suficientemente explorado e que acaba por ser importante para uma compreensão mais global da presença desse grupo nas ilhas. São as práticas culturais judaicas, que se supõe terem existido, que erigimos como objeto de pesquisa. É razoável pensar que, da parte de imigrantes com aquelas características, haveria um natural esforço para preservação da sua identidade, mormente a religiosa. Os patrónimos e alguns sinais materiais indiciadores dessa presença, nomeadamente, o topónimo «Sinagoga» na ilha de Santo Antão e os cemitérios e túmulos existentes em algumas ilhas, foram tomados como ponto de partida para a abordagem pretendida. Revisitar esses elementos e, a partir de um exame mais minucioso, efectuado à luz de dados já publicados e registos inéditos, bem como de experiências similares ocorridas em outras paragens, haveria de permitir uma leitura que fosse para além deles. 
o que apurámos nessa primeira abordagem, de reconstituição das atitudes e comportamentos desse grupo, pensamos ser tão revelador como estimulante a outras incursões sobre essa faceta da história da imigração marroquina e gibraltina do século XIX em Cabo Verde. $O$ exame acabou por exigir, também, uma hipótese explicativa da durabilidade de tais práticas. Neste caso, a razão da não reprodução continuada da cultura judaica no arquipélago.

O objetivo deste artigo é, em primeiro lugar, demonstrar que para além das evidências tumulares e patronímicas, existem outras provas documentais indiciadoras de práticas culturais e religiosas que marcaram a existência da comunidade hebraica em Cabo Verde. Em segundo, observar o processo de aculturação por que passou o grupo que, malgrado alguma resistência, acabou por perder a sua identidade original, diluindo-se quase que por completo na sociedade crioula que o acolheu.

\section{1. $A$ «Sinagoga»}

6 Que mistério guardará o pequeno porto da ilha de Santo Antão que, desde quando não se sabe bem assinalar, mereceu ser chamado de Sinagoga?

7 Situado numa diminuta baía, envolta por um minúsculo povoado que a abraça, a $4 \mathrm{~km}$ do Concelho da Ribeira Grande em direção ao do Paul, esta será, ao que se presume, a única «Sinagoga» que Cabo Verde terá conhecido. A questão frequentemente colocada é se aquele lugar terá sido, de fato, um local reservado às cerimónias religiosas da expressiva comunidade hebreia instalada na ilha, em meados do século XIX. Se ali, efectivamente, foi erigido algum edifício para oração desse grupo. Ainda que se quisesse acreditar em tal suposição, esta nunca encontrou suporte documental. E sendo que nenhum estudo, até agora, conseguiu fundamentar a razão de se consagrar tal nome àquele preciso lugar, no domínio das conjecturas há, obviamente, que considerar outras possibilidades. Não terá sido o sítio de desembarque dos judeus chegados a Santo Antão, em épocas muito mais remotas? Ou, mesmo, um local discreto de entrada e saída de mercadorias, utilizado pela "gente de nação», composta essencialmente por comerciantes? Teriam esses, em período muito menos favorável, ousado, clandestinamente, basear as suas práticas religiosas em alguma casa levantada naquela localidade?

8 Não obstante ainda permanecerem muitas questões em aberto acerca da «Sinagoga» santantonense há, todavia, que descartar a associação que dela se faz à comunidade de judeus instalados na ilha, no século XIX. Pois o que se pode provar, com toda a segurança, é ser o topónimo «Sinagoga» muito anterior a essa época, remontando, até onde pudemos apurar, aos anos 30 de setecentos ${ }^{8}$. Ou seja, mais de um século antes dos primeiros judeus, da leva do século XIX, aportarem em Cabo Verde. 


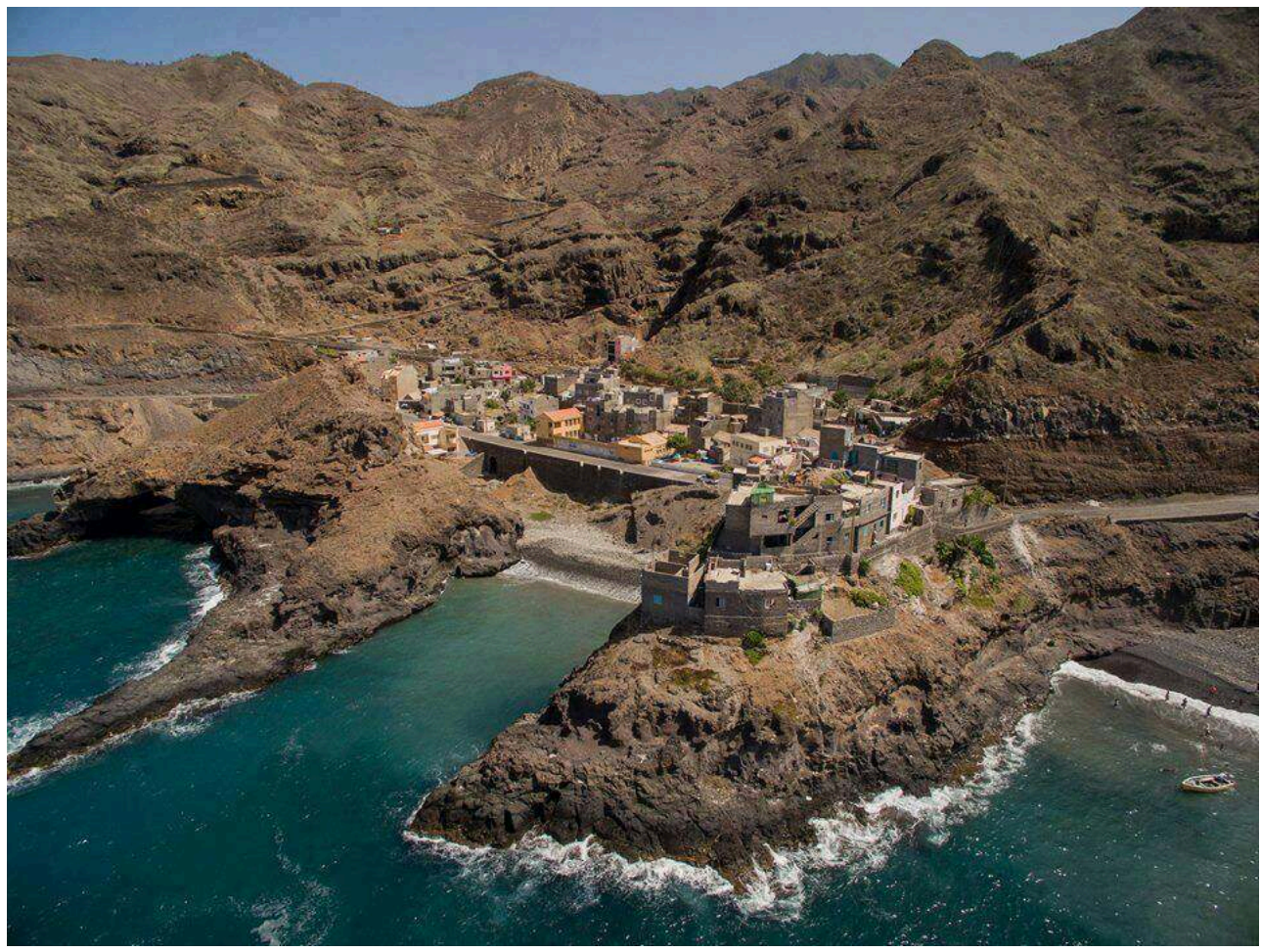

Foto de autoria desconhecida, gentilmente indicada por Humberto Lima

Mas sendo Santo Antão a ilha de maior concentração dos hebreus, que a partir dos anos quarenta de oitocentos procuraram Cabo Verde para fazer os seus negócios, não seria de esperar que, tal como aconteceu em outras paragens, essa comunidade, que chegou a reunir mais de meia centena de indivíduos ${ }^{9}$, contasse com um edifício próprio para a realização do seu culto? Só investigações arqueológicas, ainda por fazer, ou quiçá, mesmo, alguma documentação inédita, poderão ser reveladoras acerca disso ${ }^{10}$, não nos sendo permitido, até esta, senão manter a hipótese de que em todo Cabo Verde, mesmo na ilha de Santo Antão, os ritos religiosos dos hebreus tenham sido praticados exclusivamente em residências particulares.

Posto isto, será lícito perguntar: para além dos túmulos espalhados pelos sítios de morada ou por onde passaram esses judeus ${ }^{11}$ e dos apelidos de família que ainda se podem encontrar por cá, que outras evidências poderiam atestar a presença dessa notável comunidade de cultura religiosa distinta que decidiu viver em solo absolutamente católico? O fato é que não contamos com muitos mais sinais acerca da existência dessa gente de pertença hebraica que, entre a segunda metade do século XIX e primeira do XX, no seu processo de diasporização atlântica, dirigida aos territórios lusófonos, encararam essas ilhas como um ponto apetecível para estabelecimento dos seus negócios e, dependendo da sorte, até, se deixarem ficar por cá.

\section{0 alimento dos vivos e o abrigo dos mortos}

11 Mesmo que totalmente livres da secular perseguição inquisitorial, pois os tempos agora eram outros, tempos de pleno vigor do liberalismo português, os hebreus que chegaram a Cabo Verde no século XIX ${ }^{12}$ tiveram de empenhar-se para conservar a sua cultura 
religiosa. Uma portaria de 9 de abril de 1864 dá conta das diligências realizadas para que a comunidade instalada pudesse manter as leis de casher, exigente na forma de abate das carnes destinadas ao seu consumo (shechitah). O conteúdo da portaria deixa transparecer a relutância das autoridades locais em oferecer as condições para a guarda dessas leis que, no entanto contariam com o devido amparo régio. Senão, vejamos:

Representando Afflaló Bettencourt \& Cia, hebreus portugueses, que o administrador do Concelho da ilha Brava lhes proibiu que matassem as rezes, segundo o seu rito no matadouro público, pedindo providências para que em todas as ilhas lhes seja permitida a matança do gado nos matadouros estabelecidos, sujeitando-se às disposições policiais; manda Sua Majestade El-Rei, pela Secretaria d'Estado dos Negócios da Marinha e Ultramar, que o Governador geral da Província de Cabo Verde tomando esse objeto na devida consideração, expeça as ordens convenientes para que os hebreus sejam admitidos a matarem o gado, que destinarem para o seu uso, nos matadouros públicos, sem prejuízo dos outros cidadãos, e sujeitando-se às prescrições policiais necessárias, mas de forma que se lhes não embarace o cumprimento dos seus ritos, como se está praticando em Lisboa, onde no matadouro da cidade se lhes destinou lugar especial para seu mais cômodo serviço ${ }^{13}$.

O conflito irrompido na ilha Brava aponta para a existência de comunidades hebraicas em outras ilhas igualmente desejosas de autorização concernente às leis do casher. A deliberação favorável leva-nos a inferir estar, a partir de então, o problema resolvido. Mas, até lá, como teriam esses hebreus enfrentado essa questão tão essencial para a sua dieta alimentar? Abates esporádicos de carnes casher, feitos discretamente e obrigando a algum estoque para o consumo regular desses novos imigrantes, se assoma como uma possibilidade. Uma participação registada na vila da Praia, em 28 de junho de 1856, contra Jacob Seruya, um judeu natural de Gibraltar, que aqui chegou a viver, antes de se ter fixado na ilha Brava, sugere as precárias condições de armazenagem dessas carnes. A queixa apresentada por José Lourenço de Andrade, denunciando o "mau cheiro que provem de uma porção de carne salgada existente em sua casa, na rua do Cofre e do Pelourinho", levou a que Administrador do Concelho instasse o Presidente da Junta de Saúde "para legalmente proceder ao exame da respectiva carne para posteriormente dar-se-lhe o destino conveniente e em conformidade com a lei de higiene pública"14.

13 É evidente que não se podia deixar de dar andamento à deliberação régia de permitir que os hebreus fossem "admitidos a matarem o gado, que destinarem para o seu uso, nos matadouros públicos”. Mas a ordem, por si só, até que ponto seria capaz de sanar por completo os alegados conflitos ocorridos no local de abate? Em Santo Antão, onde a demanda de carne casher foi, certamente, maior, é provável que o problema tenha sido contornado pelo controle do próprio matadouro por um dos membros do grupo. É isso que nos faz pensar o fato de, em determinado período, Leão Benrós ter o "exclusivo da venda de carne de vaca" na referida ilha ${ }^{15}$.

$14 \mathrm{O}$ ano de 1864 parece ter sido um momento de afirmação da comunidade judaica radicada em Cabo Verde. Para além do êxito relativo ao shechitah, o grupo estabelecido na Praia havia de regozijar-se com os avanços alcançados por Salomão Anahory respeitante a uma outra carência, que tanto do ponto de vista prático como simbólico significava um sério óbice à observância da cultura religiosa hebraica. Obter um lugar próprio para enterrar os seus mortos, terá sido uma reivindicação não menos relevante e que, nessa altura, encontraria também acolhimento.

Um anúncio da camara municipal da Praia, datado de 11 de maio, assegurava que: 
no dia 26 do corrente mês [...] próximo ao cemitério desta cidade, se há de proceder à competente vistoria para a medição e avaliação de um terreno que Salomão Anahory pretende tomar de aforamento para servir de cemitério dos israelitas que falecerem nesta cidade" [...] "as pessoas que queiram opor-se ao mesmo aforamento, devem apresentar os seus requerimentos no ato do exame e vistoria ${ }^{16}$.

processo desta importante aquisição, que veio a contar com a liderança de um outro indivíduo da comunidade, encontraria o seu desfecho em 3 de fevereiro de 1865, num acórdão do Conselho do Distrito, que aprovava "o aforamento que a camara municipal do Concelho da Praia fez ao hebreu Marcos Cagi de um terreno nesta cidade para cemitério dos israelitas" ${ }^{17}$. Não deixa de ser curioso o fato de em Lisboa, pela mesma altura, um grupo de israelitas estar a organizar uma "subscrição para a compra do terreno do Cemitério Israelita do Alto São João - CIASJ". Um dos que se mantinham à frente desse movimento era Marcos Auday que, juntamente com um seu irmão, fez uma doação de 50.000 réis $^{18}$. Israel Cagi, sobrinho de Marcos Cagi, e com firma instalada em Cabo Verde ${ }^{19}$, "contribuiu com 22.500 réis" ${ }^{20}$.

Pelo Código de Posturas da Câmara Municipal da Praia, publicado em 23 de maio de 1894, depreende-se o instituto do cemitério privativo, ao que tudo indica, correspondente ao lote recebido por Marcos Cagi, em regime de aforamento. No seu $\operatorname{art}^{\mathfrak{0}}$ 99, capítulo IX, determinava a referida lei municipal que:

No cemitério haverá lugar separado para o enterramento dos indivíduos não católicos e que não tenham cemitério privativo, ou que não podem ter sepultura eclesiástica ${ }^{21}$. ofício de 23 de julho de 1923, a referir-se a esse cemitério:

Existe, (...), um cemitério dos israelitas, cujo terreno foi concedido a Marcos Cagi. Este cemitério não tem vedação alguma e [o] último enterramento ali feito foi em 1918, do hebreu Benjamim Alves (... ${ }^{22}$.

Da confrontação das fontes é possível concluir que: o projeto de instalação de um cemitério judaico, no município da Praia, terá ido avante com Marcos Cagi e que, só depois, pela proximidade que o mesmo guardava com o cemitério público da Várzea que, entretanto, foi-se expandindo, é que acabaria por ser incorporado a ele, na senda das orientações das novas leis da República. A anexação teria sido, de resto, facilitada pelo fato de se ter reconhecido, em 1923, que "o cemitério particular dos hebreus, não está convenientemente vedado" 2 . Hoje, o que se pode constatar, no grande cemitério da Várzea da cidade da Praia, é a existência de um espaço reservado à comunidade hebraica, albergando dez túmulos, pertencendo os mais antigos a Abraham Tarregano e a Jacob Azencot falecidos, coincidentemente, no ano de 1864. Os outros hebreus lá enterrados, a maioria pereceu nos 20 anos seguintes, ou seja, antes da publicação da referida Postura municipal: Simon Levy (1866); Abraham Benrós (1868); Maklouf Seruya (1872); Abraham El Baz (1875); Moyses Auday (1885) e, muito provavelmente, Miryam Tarregano, filha de Abraham, cujo túmulo não está datado. Os dois restantes são de data posterior: Samuel Seruya (1895) e Benjamim Alves (1918). 
Talhão judaico no Cemitério da Várzea (Praia)

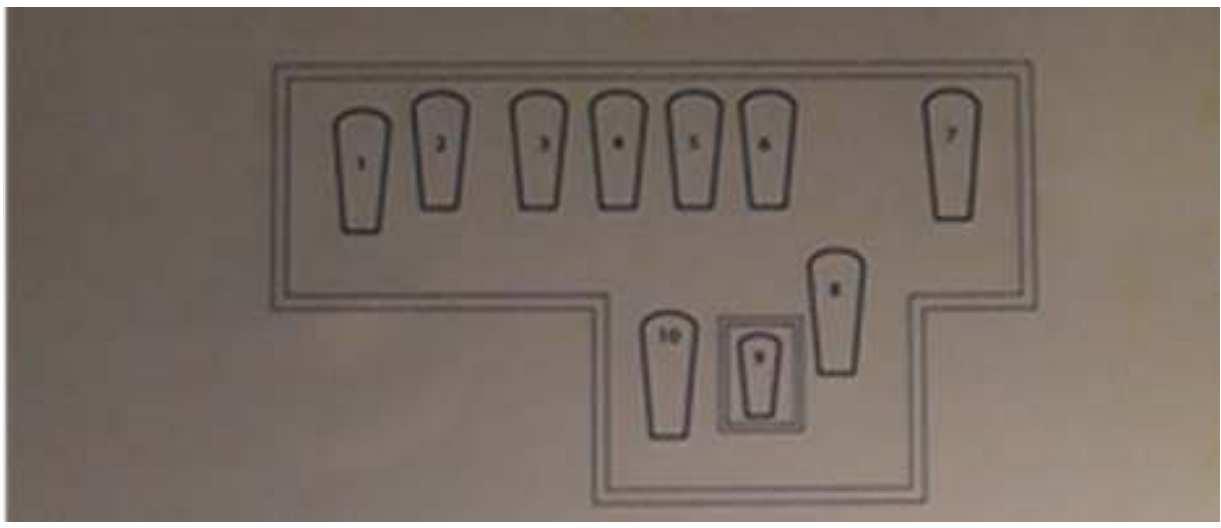

Croqui gentilmente cedido por Flávio Delgado

No «Mapa dos Europeus Falecidos no Concelho da Praia no mês de dezembro de 1868», a notícia da morte do jovem Abraham Benrós ( $n^{\circ} 4$ no croqui), constou do seguinte modo:

\author{
Abraham Benroso \\ Filiação: Moizés Benroso \\ naturalidade: Tânger \\ estado: solteiro \\ idade: 24 \\ ocupação: caixeiro \\ observações: hebreu ${ }^{24}$
}

Abraham Benrós morreu muito jovem e de igual sorte não escapou Moysés Auday (no 2, no croqui), falecido alguns anos depois. A nota de agradecimento da família Auday, aos que a haviam acompanhado nesse trágico acontecimento, atesta o fato:

Marcos Auday, Simy Auday, Bidy Auday, Rica Auday, Rechel Auday, Salomão de M. Auday, e Salomão de B. Auday veem por este meio, enquanto o não fazem pessoalmente, manifestar a sua indelével gratidão a todas as pessoas que, durante a doença de seu sempre chorado filho, irmão e sobrinho, Moses Auday, mostraram vivo interesse nas suas melhoras; outro sim, a todos os cavalheiros que os confortaram com a sua presença no passamento e acompanharam o féretro à sua última morada.

Igualmente a todas as pessoas que lhes deram provas d'estima e patentearam a sua dor e sentimento por tão doloroso transe.

Ao exmo. sr. dr. Esmeraldo Nobre o mais profundo reconhecimento, pela maneira franca e desinteressada com que assistiu ao doente, dispensando-lhe sempre muita estima, atenção, conforto e os recursos da ciência.

A exmo. sr. Theodoro Segismundo da S. e S. Bergstrom a mais imorredoura obrigação pelas provas de deferência e amizade que lhes dispensou e extremo interesse, carinho e solicitude que dispensou ao falecido, em sua doença.

A filantrópica e muito digna corporação de bombeiros voluntários praienses a mais inquebrantável estima, consideração e reconhecimento pelo espontâneo testemunho d'estima, simpatia e profundo sentimento que manifestaram ao seu consocio finado.

A exmo. sr. José Antunes d'Oliveira o penhor da mais alta estima e consideração pelos valiosos serviços, assíduo cuidado, cortesia e urbanidade com que houve para com eles no momento fatal.

A todos, verdadeiro reconhecimento e gratidão industrictivel.

Cidade da Praia, 16 de maio, de $1886^{25}$. 
22 No talhão judaico da Várzea, podemos ainda distinguir um outro hebreu cuja morte terá sido igualmente prematura. No jazigo em que se encontra encerrado $\left(n^{\circ} 3\right.$, no croqui), acompanha-o a seguinte inscrição:

Maklouf Seruya - Lápida da sepultura do saudoso jovem Maklouf Seruya, filho de Samuel, que partiu para o seu descanso eterno no $9^{\circ}$ dia do mês de Tammuz no ano de 5632 [no dia 9 de julho de 1872]. Que sua alma descanse nos laços da vida eterna ${ }^{26}$.

A sepultura de Miryam Tarregano ( $\mathrm{n}^{\circ} 7$, no croqui), visivelmente separada das demais e sem inscrição da data do seu passamento não nos permite saber se tinha de ser mesmo assim, pelo fato de ser uma jovem donzela, ou tratar-se de um caso de suicídio. É que nos preceitos da religião hebraica, "os suicidas são sempre enterrados à parte, afastados de todos os túmulos, geralmente próximos a um dos muros do cemitério"27. Fica aqui a dúvida, para investigações posteriores.

24 Nesse espaço reservado à comunidade hebraica para enterro dos seus mortos, há uma ausência que chama a atenção: a de Abraham Alves, falecido na Praia, em $1879^{28}$. Teria ele sido sepultado no mesmo jazigo que serviria, depois, para o seu filho Benjamim Alves? É que embora os túmulos judaicos sejam, por norma, individuais ${ }^{29}$, o de Benjamim Alves parece contrariar a regra, não exactamente por Abraham, do qual não há indicação de que esteja lá, mas por seus netos, Ilda Alves Pereira e Benjamim Alves Pereira, acomodados no mesmo jazigo ${ }^{30}$.

Apesar de ter-se instalado na Praia e de ter vindo a falecer nessa cidade, ao menos por algum tempo, Abraham Alves terá morado no Fogo, uma ilha onde não há qualquer referência de outros hebreus terem lá residido. Este episódio faz dele um caso singular. Terá ali vivido pelos anos 60 de oitocentos, já que $1868^{31}$, sob proposta do administrador do dito concelho, é nomeado para o cargo de "regedor de paróquia da freguesia de Santa Catarina da ilha do Fogo" 32 . 
Túmulo de Benjamim Alves e netos

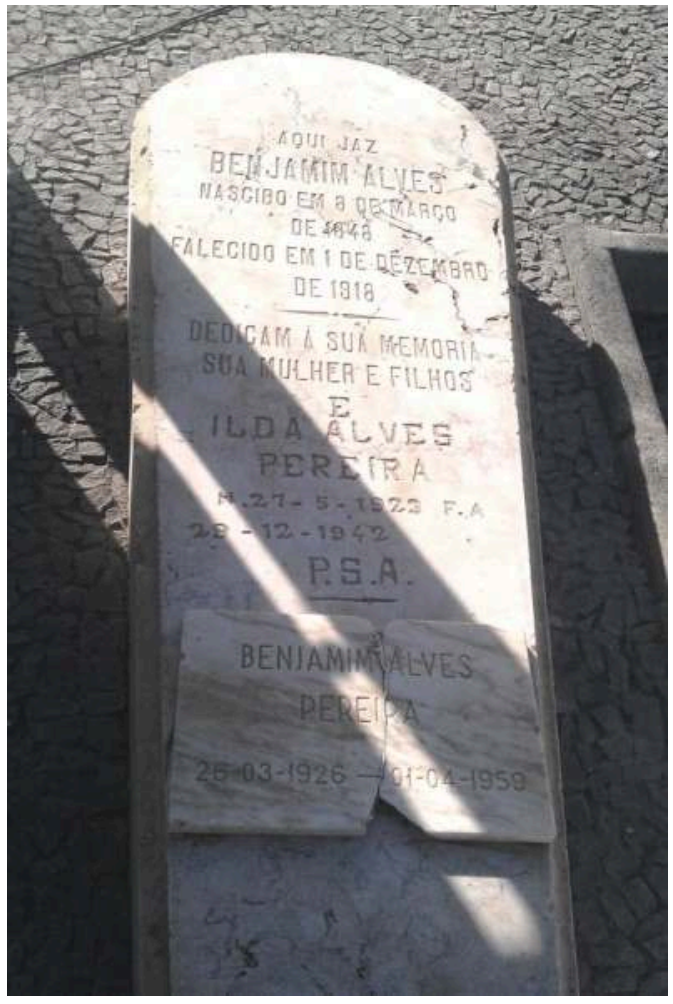

http://www.barrosbrito.com/7046.html

O que aconteceu com o cemitério israelita da Praia terá também ocorrido com o da ilha de São Nicolau onde, na ausência de fontes escritas que indiquem o processo, infere-se que assim tenha sido, por fotografias aéreas atuais, claramente denunciadoras da sua absorção pelo cemitério municipal de Tabuga.

Talhão judaico no Cemitério de Tabuga (São Nicolau)

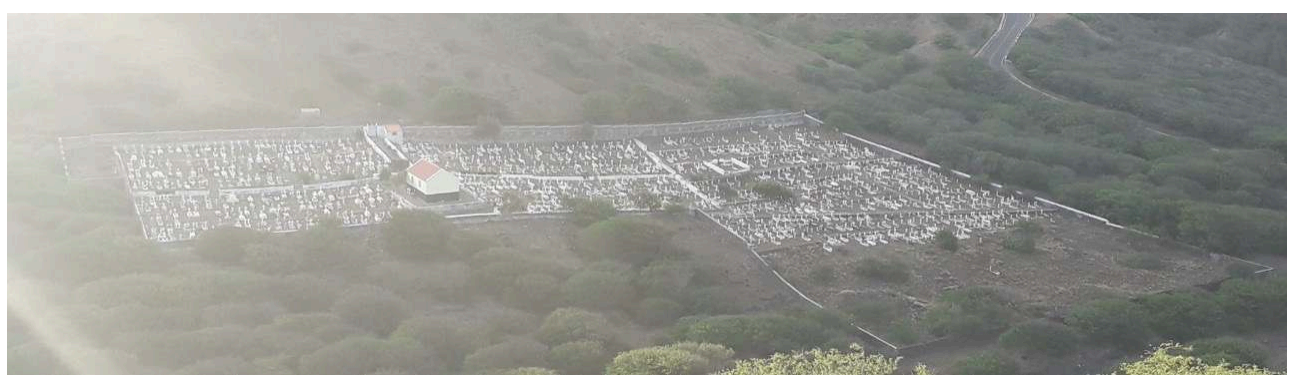

Foto gentilmente cedida por José Cabral

É ali que se encontram enterrados Salomão Pimenta, considerado um dos mais antigos hebreus que nesta fase chegaram a Cabo $\operatorname{Verde}^{33} \mathrm{e}$, o não menos remoto José Bento d'Oliveira, nascido Joseph Abithbal / Abitbol ${ }^{34}$. Salomão Pimenta era um dos poucos judeus que tinham vindo de Argel ${ }^{35}$. Morreu a 12 de julho de 1866, segundo inscrição da sua pedra tumular. Do seu desaparecimento dá-nos a conhecer um comunicado de outubro do mesmo ano, da casa Afllaló Bettencourt, da qual era sócio e que, pelo sucedido, entra em liquidação ${ }^{36}$. 
Década e meia depois era levado a enterrar o invulgar personagem a viver com nome duplo, um hebreu e outro católico, havendo também registos de estar já em São Nicolau desde os anos quarenta do século XIX ${ }^{37}$. A notícia da morte de José Bento d'Oliveira, ocorrida no ano de 1880 consta do Boletim oficial de Cabo Verde, tendo sido assim anunciada:

José Bento d'oliveira - súbdito portuguêz, casado, de 64 anos de edade, israelita, natural de Tânger, negociante, residente na ilha de São Nicolau, filho de Hassam Abitebal e Nana Abitebal ${ }^{38}$

Túmulos judaicos no cemitério de Tabuga (São Nicolau)

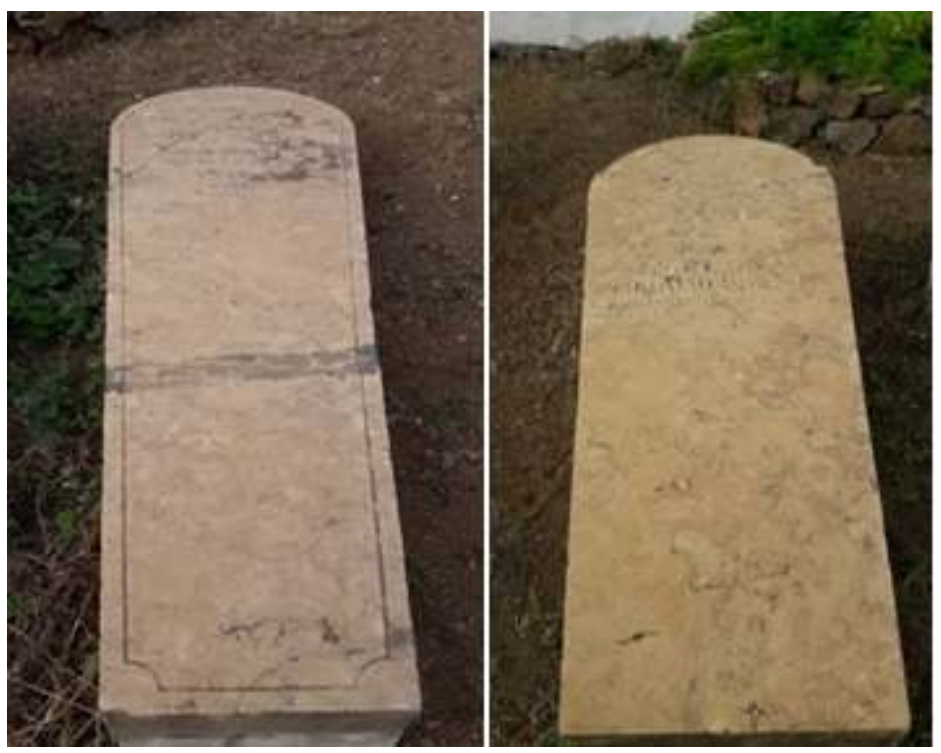

Fotos gentilmente cedidas por Djessa Oliveira e Silva

O Código de Posturas da camara municipal de Santa Catarina (Santiago), de 1893, já havia determinado no mesmo sentido do que viria a ser estabelecido para a cidade da Praia, quanto ao enterro dos não católicos. A diferença é que, no caso de Santa Catarina, decerto pela quase inexistência de hebreus, não se colocava a hipótese do cemitério privativo.

Os cadáveres cuja religião das pessoas seja diversa da do Estado deverão ser enterrados nos lugares do cemitério municipal destinados e designados pela autoridade competente $\mathrm{e}^{39}$.

Até que ponto a medida foi observada é difícil de se saber, mesmo porque não se mostrou suficientemente dissuasora para que Hillel Benchimol, falecido em setembro de 1903, fosse sepultado na sua propriedade em Pedra Barro, freguesia de Santa Catarina ${ }^{40}$. Teria sido a sua vontade? Uma espécie de resistência em deixar-se enterrar num cemitério cristão? Hillel Benchimol era originário de Oran, Argélia $^{41}$ e, tal como o jazigo solitário em que repousa, haverá, certamente, outros, ainda por identificar, espalhados pelos cantos desse arquipélago. 
Hillel Benchimol

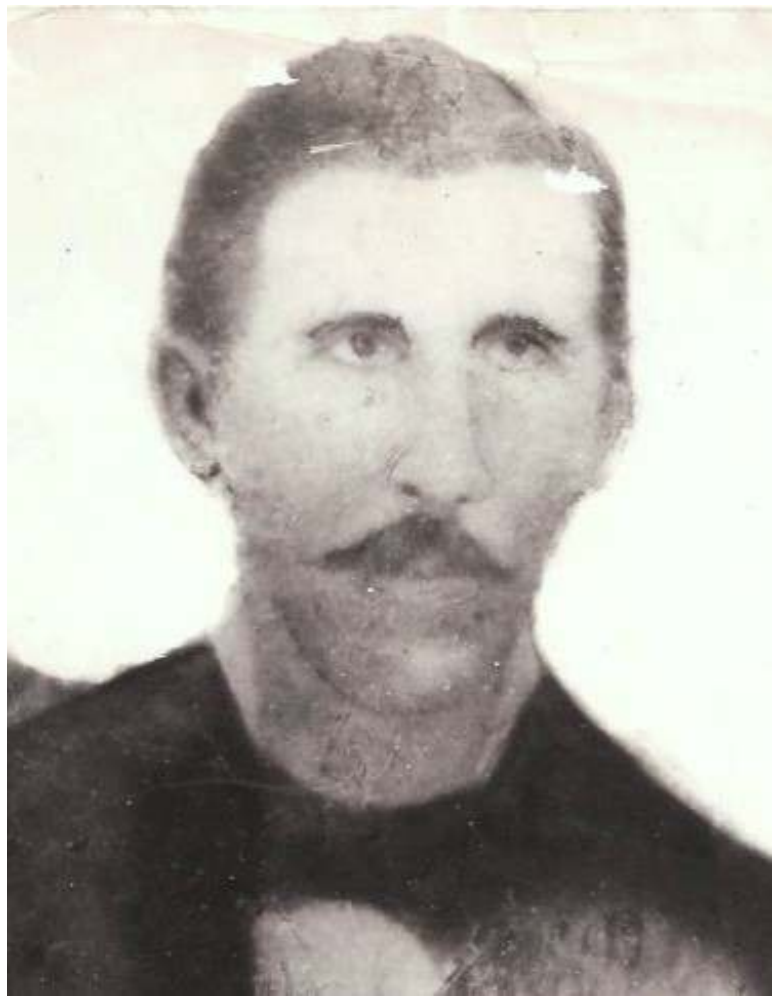

http://www.barrosbrito.com/5946.html

Túmulo de Hillel Benchimol

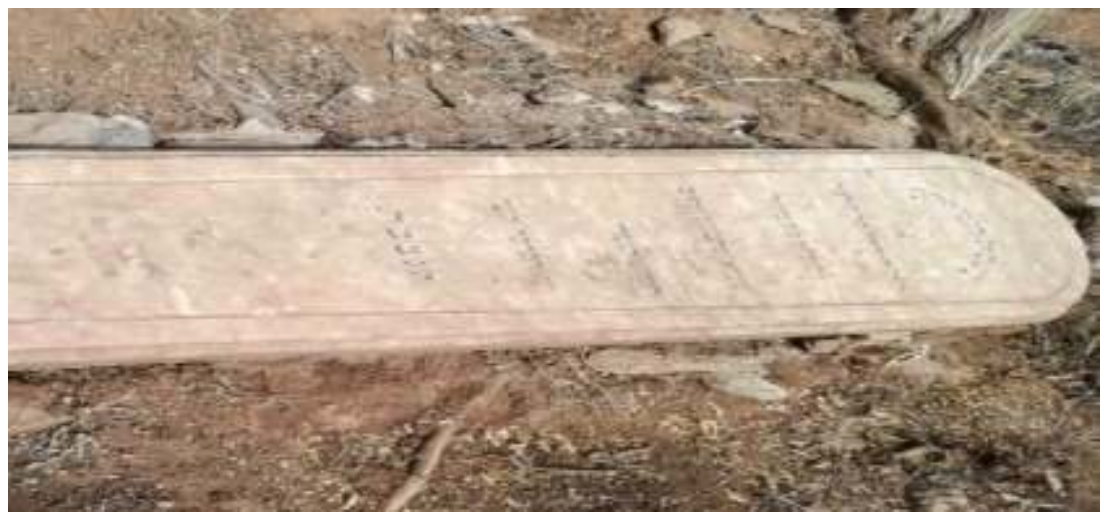

Foto de António Correia e Silva

31 Só para a ilha de Santo Antão é que o Código de Posturas, promulgado também em 1893, iria admitir uma solução diferente para a comunidade hebraica aí radicada. Neste, pode-se ler o seguinte:

Nos cemitérios públicos deste Concelho serão sepultados todos os indivíduos de qualquer nacionalidade ou culto; § único: Exceptuam-se os hebreus por terem um pequeno cemitério na vila da Ribeira Grande ${ }^{42}$.

A referência era, obviamente, ao pequeno Cemitério Judaico de Penha de França, erigido muito longe do cemitério público da vila da Ribeira Grande. Foi o primeiro cemitério privativo hebraico a ser instituído em Santo Antão. No mesmo Concelho 
surgiria, depois, um outro, o de Ponta do Sol, atestando a robustez da colonia hebraica fixada naquela ilha.

$\mathrm{Na}$ verdade, essas posturas municipais, publicadas quase que em simultâneo, resultavam de uma circular régia, de âmbito mais geral, emitida a 20 de Maio de 1882, com base numa Portaria expedida pela Secretaria de Estado dos Negócios do Reino, de 24 de janeiro de 1872. Determinava, então, a referida circular,

que nos cemitérios públicos das províncias do ultramar já existentes e nos que de futuro se construírem, se reserve uma porção de terreno sem ser sagrado, para nele serem sepultados os indivíduos a quem pelas leis canónicas é negada sepultura eclesiástica ${ }^{43}$.

Fortunato Maman, que morreu em 1870, ocupa a mais antiga sepultura do Cemitério de Penha de França (n4, no croqui). Foi seguido por Sholmo Auday, enterrado quase vinte anos depois (1889); Mazaltob Benrós (1897); Masoud Zagury (1898); Isaac Benrós (1905) e Joseph de Abraham Brigham (1907). Um último pequeno jazigo, sem identificação nenhuma, perfaz os 7 túmulos ali existentes.

Cemitério Judaico de Penha de França, Ilha de Santo Antão

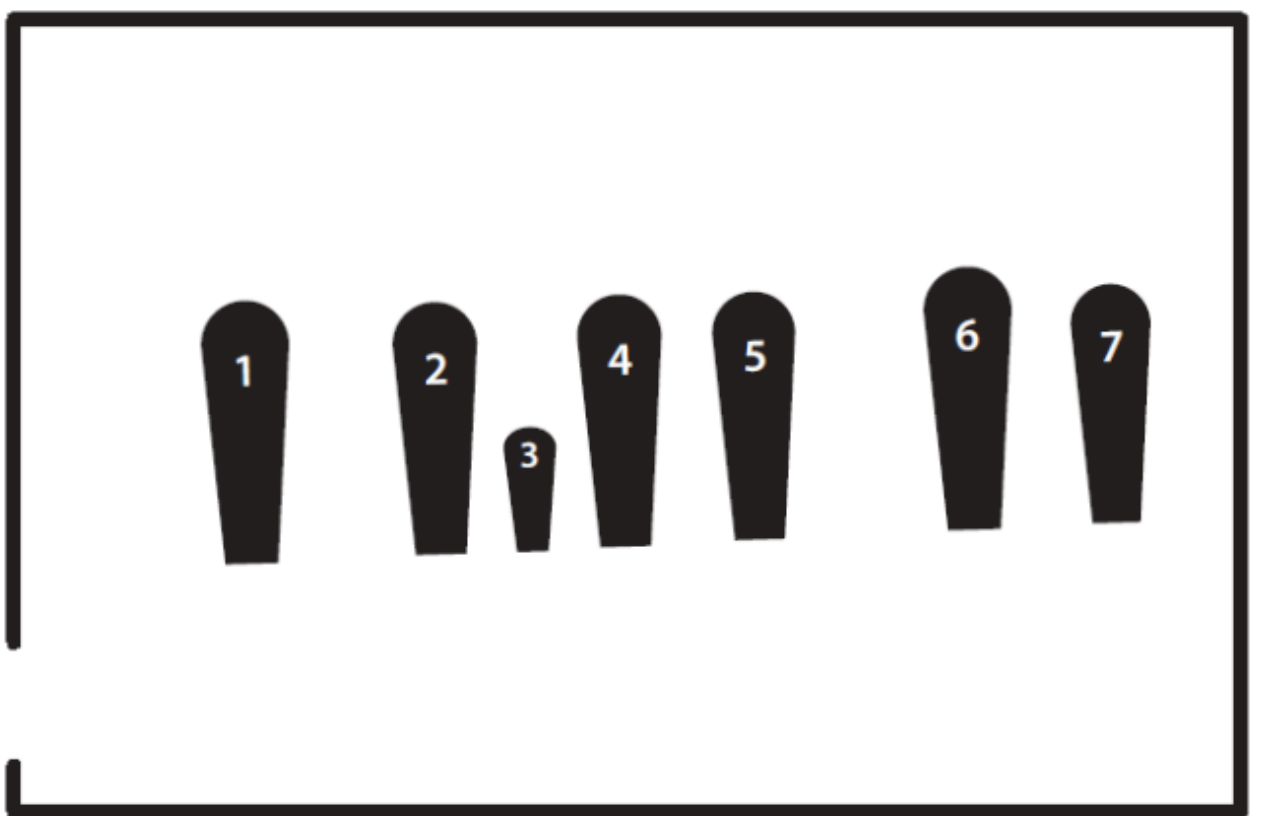

Croqui gentilmente fornecido pela Cape Verde Jewish Heritage Project

A manifestação de gratidão para com o médico que assistira o jovem Fortuanto Maman, publicada no Boletim oficial logo depois da "shivá" ${ }^{44}$, expõe os vínculos religiosos mantidos pelo grupo de judeus de Santo Antão. Vejamos o documento:

Os abaixo assinados, testemunhas oculares do assíduo e zeloso tratamento com que o Exmo Sr. Dr. Custódio José Duarte, já como médico distinto, e já como amigo dedicado assistiu de noite e de dia ao seu infeliz correligionário Fortunato Mamam durante a fatal moléstia que lhe tirou a vida, não obstante o emprego de todos os meios científicos e humanitários que o jovem médico e dedicado amigo pôs em prática para anular a sentença de morte que o Ente Supremo havia pronunciado contra o desditoso mancebo; faltariam aos deveres de homens de bem se deixassem 
de aproveitar este meio para significar a S. Excia os seus cordiais agradecimentos e eterno reconhecimento.

Receba pois S. Excia estas insignificantes linhas como expressão da mais pura, sincera e verdadeira estima, gratidão e reconhecimento dos abaixo assinados, que jamais olvidarão os valiosíssimos serviços que, na pessoa do finado Fortunato Maman, receberam de S. Excia a quem pedem licença para fazer pública esta sincera manifestação.

Os abaixo assinados suplicam ao Ente Supremo uma dilatada, próspera e gloriosíssima vida para o Exmo. Sr. Dr. Custódio José Duarte.

Ilha de Santo Antão, 18 de dezembro de 1870. M arcos Auday, Abrão Azaincot, Isaac Benros, Isaac Pinto, James Levy Bentubo, Guidon Elcaim, Fortunato Azagury, David Abecassis, Arão Benros ${ }^{45}$.

O comunicado distingue-se, no estilo e na contenção, de muitos outros similares divulgados por indivíduos da comunidade cristã, nada propensos a afirmarem-se como «correligionários» e a clamar pelo «Ente Supremo».

Com os olhos fixos na $3^{a}$ campa do Cemitério de Penha de França atentamos para as dimensões que apresenta, sugerindo ser de uma criança ou de um recém-nascido. A ausência de qualquer inscrição, acerca de quem estaria lá enterrado e a data do óbito, indica tratar-se de um feto ou de um bebé falecido antes de completar um mês de vida. Nesses casos não se supõe qualquer cerimónia religiosa, havendo ainda o costume antigo de esses túmulos não serem marcados e nem os pais e familiares participarem do "discreto enterro"

O Cemitério Judaico de Ponta do Sol, erigido já em fins do século XIX, evidencia a concentração de hebreus na ilha de Santo Antão. Situado ao cimo e bem próximo do grande cemitério público, esse espaço privativo contém o mesmo número de campas do que o de Penha de França: 7. Terá sido inaugurado pela única mulher que lá foi a enterrar, no ano de 1894: Mena Pinto, à qual, imediatamente, foi-se juntar Salomão Auday, falecido no mesmo ano (1894). Vieram, depois, Marcos Auday (1900), Joseph Mor Yoseph (1914), Isaac Pinto (1921), Moses Cohen (1929) e Abraham Julião Brigham (1941).

Cemitério Judaico de Ponta do Sol, Ilha de Santo Antão

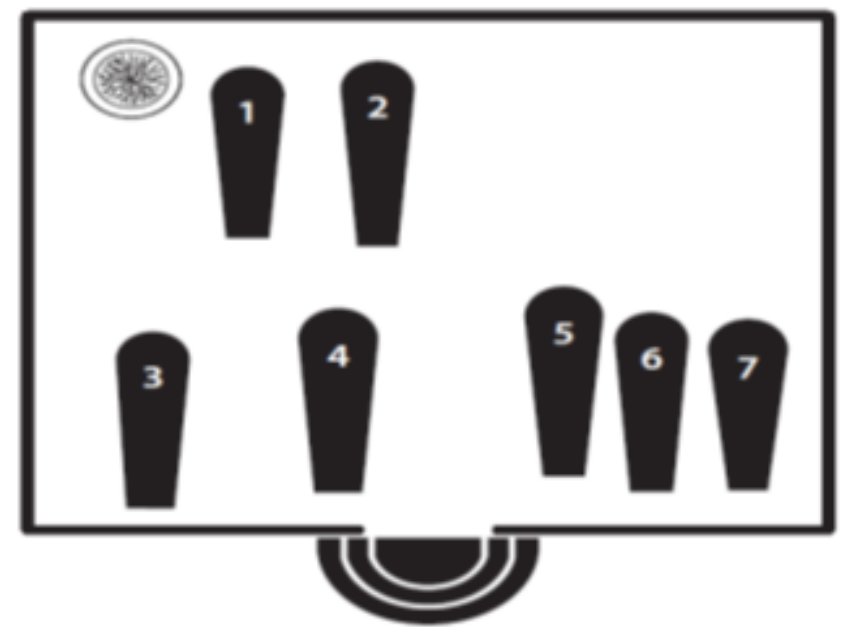

Croqui gentilmente fornecido pela Cape Verde Jewish Heritage Project

Merece particular atenção, a localização do túmulo de Moysés Cohen neste espaço sagrado (n4, no croqui). Tratando-se de um Cohen, a escolha do sítio para o jazigo não podia ser aleatória, exigindo a tradição que ficasse "próximo aos portões do cemitério para 
que seus parentes não se profanem caminhando perto de outros túmulos"47. O lugar destinado a esse hebreu no Cemitério Judaico de Ponta do Sol assinala a observância de mais este preceito religioso. Moysés morreu aos 64 anos de idade. 0 seu irmão mais velho, David Jacob Cohen, embora tenha também vivido por muito tempo em Santo Antão, terminou os seus dias na Inglaterra ${ }^{48}$.

No lado oposto do portão, um pouco mais afastado da entrada e assente num nível mais acima, deparamo-nos com o jazigo do destacado comerciante Marcos Auday ( $n^{\circ} 5$, no croqui). Marcos, que primeiramente morou na ilha de Santiago (Praia) ${ }^{49}$ e, depois, em São Vicente ${ }^{50}$, acabou, finalmente, por se estabelecer em Santo Antão. No cemitério de Ponta da Sol foi a enterrar, em dezembro de 1900, com o seu nome escrito em hebraico: Mordechai Auday, um homem "justo", "puro" e "sábio", segundo se pode ler na sua pedra tumular ${ }^{51}$.

41 José Maria Abecassis sublinha o dinamismo deste hebreu junto à comunidade israelita da capital portuguesa, especialmente pela participação que teve no processo compra do terreno do Cemitério Israelita do Alto de São João (CIASJ). Daí, aquando do seu falecimento, o Comité Israelita de Lisboa ter mandado exarar em ata da sua $39^{a}$ reunião, a seguinte nota de pesar:

Voto de sentimento - O Presidente enaltecendo os serviços prestados pelo Exmo. Snr. Marcos Auday (Q.D.T.) tanto em Lisboa como em Cabo Verde onde infelizmente faleceu, propôs um voto de profundo sentimento por perda tão sentida. Esta proposta que foi unanimemente aprovada será notificada à viúva e filha de tão benemérito extincto ${ }^{52}$.

Para além de Marcos, é possível reconhecer, nesse cemitério, um outro membro da família Auday: Salomão Auday ( $\mathrm{n}^{\circ 7}$, no croqui), presumivelmente irmão de Marcos e que, que por vezes vem referenciado como Salomão de M. Auday ${ }^{53}$, foi inumado em 26 de junho1894, com a mesma idade que Moses Cohen: 64 anos $^{54}$.

É provável que à morte de Salomão Auday estejam relacionados os éditos postos logo a correr, pelo Juízo de direito da Comarca de Sotavento e cartório do $1^{\circ}$ o ofício, mediante a justificação...

requerida por Marcos Auday, casado, negociante, natural de Tanger, ora residente na ilha de Santo Antão, em que pretende justificar: - que é maior pela legislação portuguesa, que o é também pela religião da lei israelita; que tem mais de um, de dez e também de vinte anos de residência permanente em território português, e, finalmente que, pela sua profissão, tem meios de subsistência suficientes ${ }^{55}$.

44 A norma que impunha às necrópoles públicas a reserva de uma área separada para os não católicos terá prevalecido ainda na ilha Brava onde, no cemitério de Santo António, inaugurado em 1896, se viu resguardada uma ala distinta para os que não professassem a religião oficial ${ }^{56}$. Situação diversa, encontraremos na ilha da Boa Vista, pois, tal como em Santo Antão, na Praia e em São Nicolau, os hebreus chegaram a se beneficiar de um pequeno cemitério no sítio de Pico Rixa.

No seu artigo "A questão do cemitério israelita da ilha da Boavista (1915-1923)", Cláudia Correia apresenta um documento que nos permite examinar a experiência da comunidade hebraica instalada na ilha, no que toca ao enterramento dos seus mortos. $O$ móbil do artigo, não será demais sublinhar, foi a contenda gerada em torno da morte de Isaac Benoliel, impedido pelo Administrador do Concelho de ser enterrado em Pico Rixa. Isaac Benoliel, falecido em 1915, portanto, já com as leis da República em pleno 
vigor, foi o único judeu da Boa Vista a quedar-se solitariamente no cemitério municipal do Rabil.

Isac Benoliel

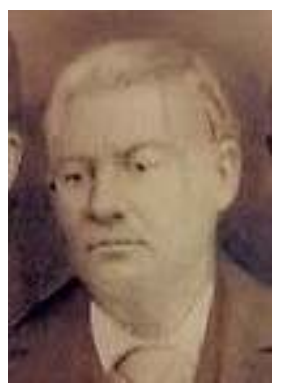

http://www.barrosbrito.com/10388.html

O texto abaixo reproduzido, é da responsabilidade do Comité Israelita de Lisboa, chamado a intervir, junto do Ministro das Colónias, no sentido fazer valer, na Boa Vista, a antiga prática de enterramento dos hebreus daquela comunidade no seu cemitério privativo:

Excelentíssimo Senhor Ministro das Colónias

Exmo Senhor

No arquipélago de Cabo Verde, na ilha da Boavista, no lugar de Pico Rixa, existe um cemitério israelita em que os israelitas residentes na mesma ilha fazem o enterramento dos seus mortos há mais de quarenta anos. Sucede, porém, que ultimamente morreu um israelita na mesma ilha e o Exmo. Sr. Administrador não consentiu fazer o enterramento do morto naquele cemitério privativo, como era costume fazer-se e obrigou a que se efectuasse no Cemitério Municipal; o que efectivamente se cumpriu apesar da dor que esta circunstância lançou sobre a família sobrevivente por ver assim feridas as suas crenças religiosas e as do morto que durante a vida aderira com fervor às leis de Moisés.

Ao Comité israelita de Lisboa, Excelentíssimo Senhor Ministro, compete pelos seus estatutos [...] defender os interesses israelitas, dos seus correligionários residentes quer no Continente quer nas Possessões Portuguesas e sentindo-se aquele alarmado pela proibição do enterramento do seu correligionário no local particularmente destinado para este fim, vem muito respeitosamente pedir Vossa Excelência se sirva providenciar para que os enterramentos dos israelitas falecidos naquela ilha continuem a ser feitos no seu cemitério particular, como até agora se praticava.... ${ }^{57}$.

Os “correligionários" da Boa Vista enterravam os seus mortos em Pico Rixa "há mais de quarenta anos", o que nos faz remontar ao último quartel do século XIX. O registo mais antigo de inumação terá sido, mesmo, o de 24 de abril de 1873, correspondente ao de uma criança, com o nome de Judah Benoliel ${ }^{58}$. A seguir, contamos o de Bidy Auday Benchimol, falecida em abril de 1887. A notícia do passamento de Bidy é transmitida, muito laconicamente, no Boletim Oficial:

No dia 24 faleceu D. Bedy Auday Benchimol, natural de Lisboa ${ }^{59}$.

Os outros nomes reconhecíveis nas lápides de Pico Rixa (ou "Roxinha") são também da família Benoliel: os fundadores da casa na ilha da Boa Vista, Esther Benatar Benoliel (1891) e Abraham Benoliel (189?) e dois dos seus filhos, José Benoliel (1923) ${ }^{60}$ e David Benoliel (1950). Mais duas sepulturas não identificadas perfazem as 8 que este cemitério alberga actualmente, encontrando-se, a maioria delas, numa das duas alas que o compõe. Sublinhe-se o fato incomum da divisão interna existente no Cemitério de Pico Rixa, estabelecida por um pequeno muro. Ocorrência única em Cabo Verde, que o estado das investigações ainda não permite explicar. 
$\mathrm{O}$ conflito surgido à volta do sepultamento de Isaac Benoliel fez correr muita tinta $\mathrm{e}$, num dossier que se arrasta até 1923, reconstrói-se um pouco da história desse cemitério. Atentemo-nos às considerações do Administrador do Concelho da Boa Vista, Francisco Tavares de Almeida, lavradas num ofício emitido na sequência da inquirição a que foi submetido, por causa do incidente:

( ... ) cumpre-me dizer: Nunca existiu nesta ilha cemitério de israelitas ou de indivíduos de qualquer outra religião.

As autoridades administrativas permitiram que os israelitas falecidos fossem enterrados em sítio perto de 'Pico Rixa' recinto que foi cercado por um muro de alvenaria de altura de 1,40 metros.

Dão acesso a estes recintos, - são dois - umas aberturas, espécie de janelas, sem portas, a cerca de $0,55 \mathrm{~m}$ do terreno, o que permite entrada de pessoas e mesmo de animais.

Nunca a colónia israelita tratou de regularizar a concessão do terreno, vedá-lo convenientemente, e por isso nunca pôde ser considerado como cemitério. É para notar: que os primeiros israelitas falecidos, deixaram descendentes com bastantes meios, e até ao presente não trataram de regularizar um assunto que tão de perto lhes toca, e a que são moralmente obrigados a fazer.

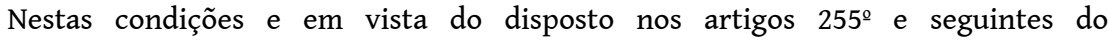
Regulamento do Registo Civil, só depois de devidamente regularizado o assunto, pode ser permitido o enterramento dos não católicos nos cemitérios privativos. (...) Tenho ainda a dizer: o primeiro cercado tem duas pedras tumulares, sem capacidade para mais; o segundo tem quatro sepulturas, e só dá lugar a mais uma $(\ldots)^{61}$

Croqui do cemitério de Pico Rixa (1915)

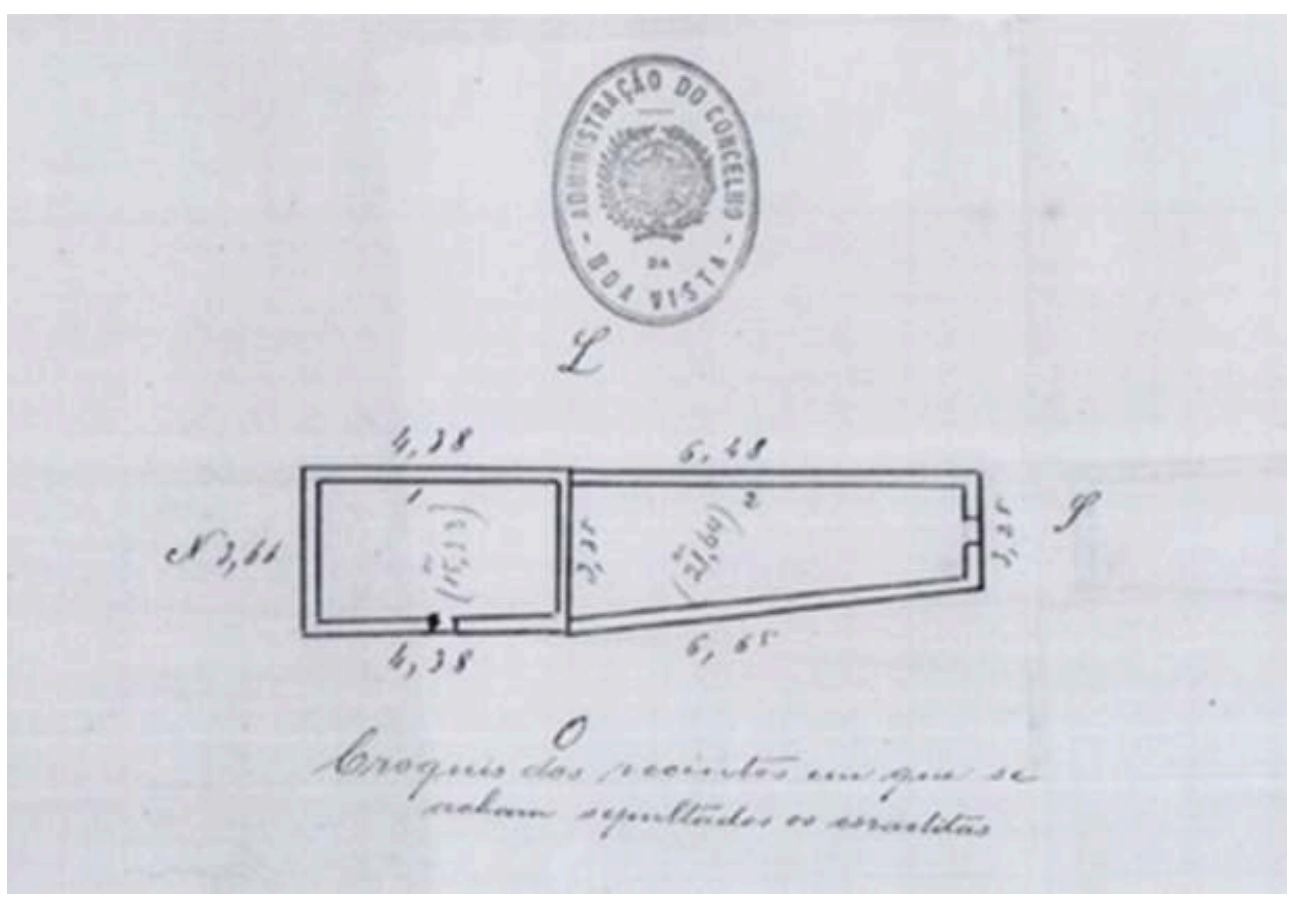

Croqui do Administrador do Concelho da Boavista Francisco Tavares de Almeida e que acompanha um ofício datado de 9 de junho de 1915

José Benoliel, já nascido na Boavista era, na altura da celeuma gerada em torno das exéquias do seu tio Isaac, representante do Comité Israelita de Lisboa em Cabo Verde. Foi nessa qualidade interveio no processo, aproveitando o ensejo não só para tentar 
regularizar a situação do cemitério como, ainda, solicitar a sua ampliação ${ }^{62}$. Num Parecer do Delegado do Procurador da República da Comarca de São Vicente, constante do aludido dossier, fica evidente o alcance limitado daquelas pretensões, pouco oportunas, no entender do oficial:

José Benholiel, casado, proprietário, natural e residente na ilha da Boa-vista requereu que lhe sejam concedidos de aforamento $200 \mathrm{~m}$ de terreno sito no lugar denominado Pico Rixa, terreno que deseja privilegiar para o efeito de ali serem enterrados os israelitas que falecem na ilha da Boa-vista (...) O requerente parece ser aqui o representante da comunidade israelita de Lisboa. Pelo croqui do administrador da Boa-vista vê-se que o requerente pretende não só que os israelitas continuem sendo enterrados no local referido (...) mas também o alargamento do mesmo cemitério (...)

Parece que o enterramento dos israelitas na ilha da Boa-vista se fazia por mera tolerância das autoridades locais. De outra forma não seria explicável, o pedido de aforamento agora feito. Entretanto há que respeitar o que podemos chamar. Para as famílias israelitas esse lugar é sagrado e não seria razoável desrespeitar o lugar onde estão os restos mortais dos seus antepassados direitos adquiridos.

(...)

Visto o que acabámos de expor rapidamente concluímos:

1 ) Que poderá ser permitido que se continuem fazendo no sítio de Pico Rixa da Boavista os enterramentos dos israelitas, provisoriamente, sob a fiscalização da Câmara e correndo as despezas por conta dos interessados, isto para evitar-se ferir crenças e direitos que são de respeitar.

2) Que se não conceda a ampliação pedida do cemitério, sujeitando-se o caso à deliberação das estações [instâncias] superiores"63.

51 Desenvolvimentos ulteriores confirmam que o Cemitério de Pico Rixa se manteve exactamente como estava, ou seja, nem a sua ampliação foi autorizada, nem, tão pouco, foi levada adiante a legalização requerida. Mesmo no tempo em que José Benoliel exerceu a função de Administrador do Concelho da Boavista (1919), não há notícias de nenhum avanço quanto a isso ${ }^{64}$. Todavia, em consonância com o ajuste a que se conseguiu chegar, puderam os israelitas da Boa Vista continuar a fazer os seus enterramentos no local, "sob fiscalização da Câmara e correndo as despezas por conta dos interessados". E disso pôde beneficiar-se o próprio José Benoliel que, tendo falecido na cidade da Praia, a 7 de julho de 1923, foi trasladado, no palhabote Edith, para o cemitério de Pico Rixa, onde foi sepultado em 14 de março de $1924^{65}$. Contava, apenas, com 52 anos de idade. 


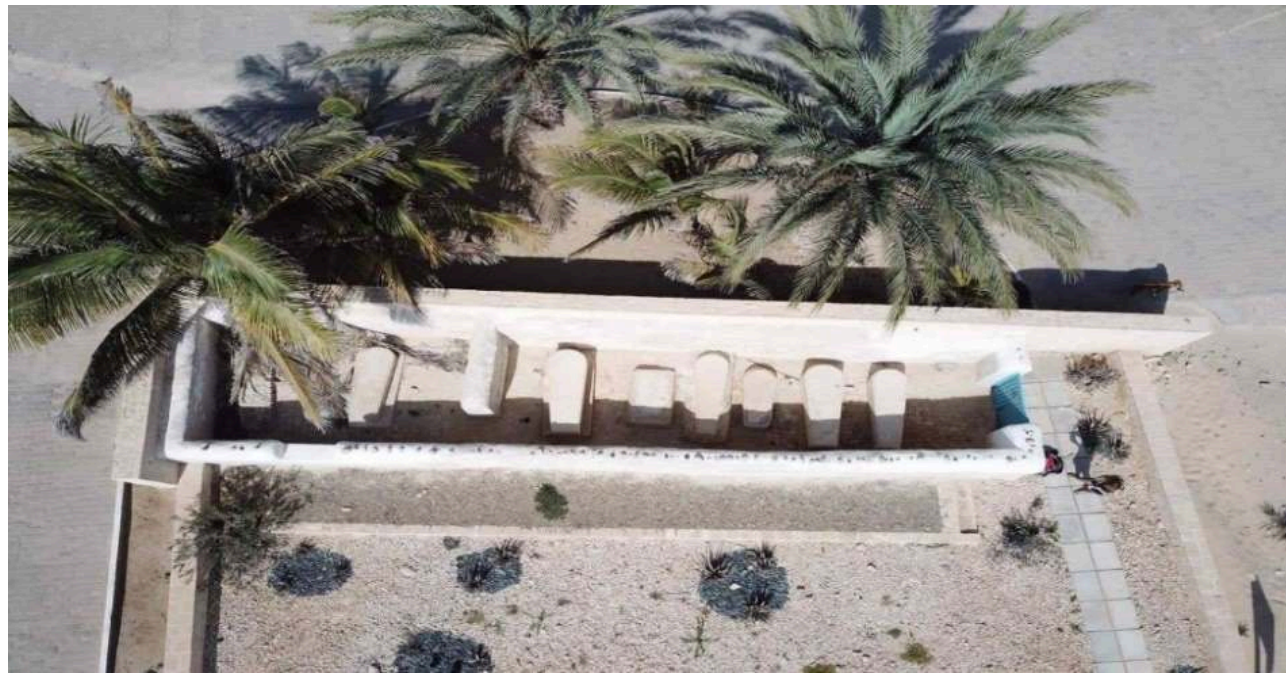

Foto de Ginevra Rossi, indicada por Nereida Tavares

Mindelo, ilha de São Vicente, foi dado logo depois, no no 222 do Notícias de Cabo Verde:

James Wahnon

Outro amigo que faleceu nesta cidade em 20 deste mês e foi enterrado na manhã de 21 do Cemitério inglês, foi Jayne Wahnon, natural desta cidade, de 66 anos de idade, filho do sr. Isaac Wahnon e de D. Raquel Levy Bentubo Wahnon, já falecidos.

Era também muito estimado pelos seus numerosos amigos.

A toda a família enlutada, que é bastante numerosa, enviamos os nossos sentimentos de pesar, em especial a seu filho Sr. Carlos Pinto Wahnon e a seu irmão sr. Jacob Wahnon, ambos nossos queridos amigos ${ }^{66}$.

James, Jonas e Jacob, assim como as suas dez irmãs - Simy, Ernestina, Camila, Miryam (Merima), Regina, Laura, Aldegundes, Carmen, Judith e Lea -, eram filhos de um casal gibraltino que, antes ir viver na ilha de São Vicente, havia fixado residência em Santo Antão. Exceto Jonas, Simy e Judith, nascidos nessa ilha (Paul), todos os outros são do Mindelo. A nacionalidade britânica dos pais, a que tiveram direito, justifica a inumação de James (ou Jayme) no cemitério privativo que os ingleses mantiveram por largos anos em São Vicente, no actual sítio chamado «Chã de Monte Sossego». Como filho de hebreus, presume-se que o jazigo de James tenha obedecido a tradição. Outros da família Wahnon terão estado ali também, mas, infelizmente, nada sobrou desse cemitério, desmantelado em meados do século XX. Presumivelmente os pais de James, Isaac e Raquel, falecidos em 1915 e 1927, respectivamente, também lá tenham sido enterrados ${ }^{67}$ e, nesta medida, maior conviç̧ão ficamos quanto à configuração dos seus túmulos. A dúvida quanto destino final do casal advém de um anúncio publicado no Boletim oficial de Cabo Verde:

Isaac Wahnon, esposa e filhas, retirando-se deste arquipélago para as Canárias, e não podendo despedir-se pessoalmente de suas filhas, genros e netos e daqueles que durante a sua longa permanência nesta província lhes testemunharam amizade, o fazem por este meio e oferecem seus fracos préstimos em Las Palmas, Grã Canária, onde vão residir. São Vicente, 26 de março de $1909^{68}$.

54 Teriam voltado para Cabo Verde e morrido em São Vicente? O autor de um importante estudo genealógico sobre a família Wahnon"69, da qual descende, afirma que sim. Que tanto Isaac como Raquel morreram em São Vicente e que ela, inclusive, teria partido de 
Lisboa para São Vicente no navio «Niassa», a 1 de abril de 1927, tendo falecido, no Mindelo, a 27 de Setembro do mesmo ano. Nesse caso, em especial, a não conservação dos jazigos afigurar-se-ia como mais uma importante perda para o património histórico da ilha de São Vicente e de Cabo Verde.

Mas se para os portadores de nacionalidade britânica o cemitério inglês parece ter sido a solução possível, que sorte estaria reservada aos hebreus de outra nacionalidade, como Abrahão Azancot, falecidos em São Vicente? Oriundo de Marrocos, Abrahão Azancot teve o mesmo percurso que os pais de James: estabeleceu-se primeiramente em Santo Antão ${ }^{70}$, seguindo, depois, para São Vicente ${ }^{71}$. No «Extrato dos Relatórios das diferentes ilhas d'este Arquipélago...» publicado num dos números do Boletim Oficial de Cabo Verde de 1884, no item respeitante a São Vicente, mês de Setembro, a notícia foi comunicada:

No dia 18 faleceu Abrahão Azancot, natural de Tânger, de 64 anos de idade, casado ${ }^{72}$. A mesma dúvida sobrevém acerca do sepultamento de Isaac Zaffrany, falecido em $1897^{73}$ e cujo inventário orfanológico ficou ao encargo de Isaac Wahnon. Nascido em Mogador, Isaac Zaffrany, estabeleceu-se no Mindelo, depois de ter vivido muitos anos nos Açores ${ }^{74}$. Foi casado duas vezes, primeiro com Raquel Ben Saúde, em Ponta Delgada e, depois com Felicidade (Mazaltob) Zagury ${ }^{75}$ mas, ao que tudo indica, terá ido sozinho para Cabo Verde. $O$ anúncio do juízo municipal da ilha de São Vicente, "chamando e citando os herdeiros de Isaac Zaffrany, residentes em parte incerta em Portugal e em Lourenço Marques"76, denuncia as ligações que esse comerciante mantinha com Moçambique, muito provavelmente, onde havia fixado a sua base familiar ${ }^{77}$.

Não sendo ainda possível localizar o jazigo de Abrahão Azancot, nem o de Isaac Zaffrany, o mesmo não se passa com o de Simy Benoliel de Carvalho, uma hebreia de segunda geração como, aliás, também o era Jayme Wahnon, falecida no Mindelo em $1929^{78}$. Simy, das filhas, a mais velha de Abraham e Esther Benoliel, era da Boa Vista, terra onde os seus pais se haviam instalado, entre fins dos anos 50 e início dos 60 de oitocentos. Cresceu na sua ilha natal e lá se casou com António Miguel de Carvalho, com quem veio a ter nove filhos ${ }^{79}$ (ou dez?) ${ }^{80}$. Embora o consorte não fosse judeu, a avaliar pelo tipo de sepultura em que descansa e pela manutenção da religião hebraica por alguns dos seus filhos, nota-se que Simy nunca chegou a abdicar de todo das suas raízes. Morreu da mesma forma como nasceu e, sob uma campa tipicamente judaica, desejaram os seus que ficasse para sempre lembrada como "uma extremosa esposa, e uma santa mãe, e muito amiga dos pobres"81. 


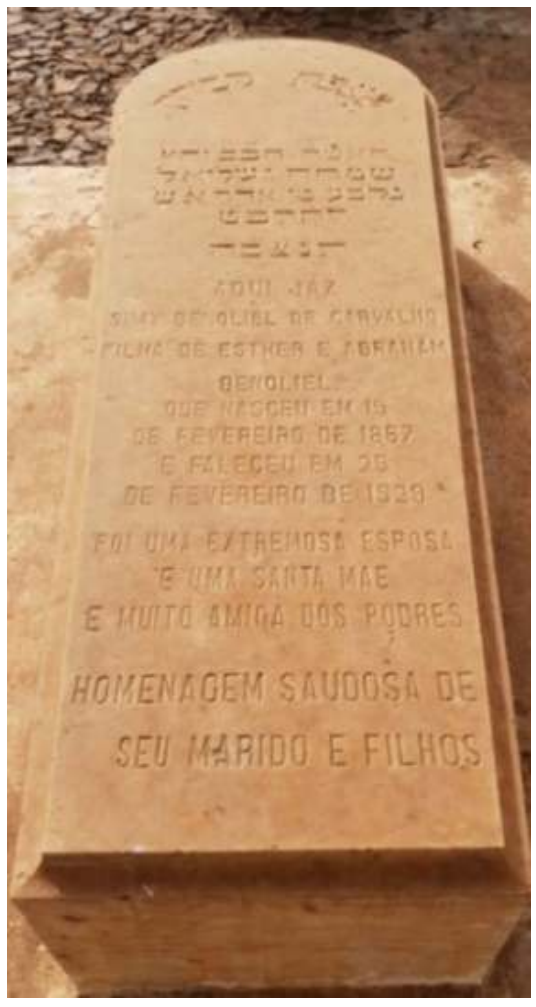

http://www.barrosbrito.com/8772.html

Isaac Pinto, filho de Jacob e Mena Pinto, também faleceu em São Vicente, no dia 5 de outubro de 1921. Mas, tal como sucederia depois com José Benoliel, que tendo sucumbido na Praia, foi trasladado para a Boa Vista (1923-1924), Isaac Pinto foi levado a enterrar na terra onde sempre viveu. Por isso, poderá ser encontrado no Cemitério judaico de Ponta do Sol, na ilha de Santo Antão ${ }^{82}$. Na sessão da Camara municipal de 11 de maio de 1928, realizada nos Paços do Concelho recém-inaugurado na referida vila, o vogal José Lopes proporia que lhe fosse feita a seguinte homenagem, "que foi unanimemente aprovada":

que logo que seja possível se adquira um retrato do falecido Isaac Pinto que bem ficará neste salão, pois a este saudoso extinto se deve muito a vila de Ponta do Sol em que ele fez construir um grande número de prédios e a cujo engrandecimento material deu o melhor dos seus esforços - proposta $^{83}$.

\section{0 profundo silêncio do jazigo das mães judias}

57 No ocaso do século XIX já se podia contabilizar, no conjunto dos cemitérios judaicos fundados em Cabo Verde, um número significativo de hebreus da primeira geração. Alguns sucumbidos prematuramente, como os jovens Simon Levy (1866/ Praia), Abraham Benrós (1868/ Praia), Fortunato Maman (1870/ C.J. de Penha de França - Sto Antão), Maklouf Seruya (1872/ Praia); Moses Auday (1886/ Praia); Samuel Seruya (1895/ Praia); e Myriam Tarregano (? / Praia), mas outros com uma longevidade admissível ou mesmo elevada para a época. Fazem parte desse segundo grupo três mulheres que, na companhia dos seus maridos, sabe-se lá com que meios e dificuldades, foram desafiadas a manter, em solo tão estranho ao das suas origens, a função de mães judias. Referimo- 
nos a D. Esther Benholiel, falecida em 1891 (C.J. de Pico Rixa); Mena Pinto, em 1894, aos 64 anos (C.J. de Ponta do Sol); e Mazaltob Benrós, em 1897, com 85 anos de idade (C.J. de Penha de França). Outras, que também criaram os seus filhos nas ilhas, poderiam, a bem da justiça, ser acrescentadas a esta lista se lhes fossem localizados os jazigos (é o caso de Raquel Levy Bentubo Wahnon) ou, ainda, se por obra do destino ou vontade própria, não acabassem por sucumbir na terra natal ou em distintas paragens. Entre essas últimas estarão, decerto, as matriarcas Simy Auday, Esther Alves e Esther Brigham.

A investigação levada a cabo por Ângela Benoliel Coutinho é reveladora quanto à presença feminina no quadro dessa emigração hebraica do séc. XIX, apontando a autora, na relação que faz, aquelas que já eram, aumentaram a prole ou se tornaram mães em Cabo Verde. Indica a autora que:

Isaac Gabay vivia acompanhado da sua esposa e tivera um filho em Santo Antão; Guidom El Caim, de Rabat, também vivia com a esposa, tendo uma filha nascida em Tânger e três filhos nascidos em Santo Antão, Izaac Zaffrany também surge como casado; Moses Abecassis casou-se em Santo Antão, na Ribeira Grande, com Simy, natural de Tânger. Tiveram uma filha em Santo Antão e outra em São Vicente ${ }^{84}$.

A esta lista podemos, ainda, acrescentar mais dois casais de Tânger: Augusto (Ayush) Ezaguy e Fortunata (Messoda) Ruah que tiveram, pelo menos, oito filhos em Cabo Verde (Joseph Augusto Esaguy (Cabo Verde,/?), Marcos Augusto Esaguy (Santo Antão, 1866), Isaac Augusto Esaguy (Santo Antão, 1869), Raquel Esaguy (São Nicolau, 1872), Samuel Augusto (Ilha de São Vicente, /?), Salomão Augusto Esaguy (Santo Antão, 1882), Pacífico Augusto Esaguy (São Nicolau, 1883) e Miquelina Esaguy (São Nicolau, 1885) ${ }^{85}$; e Jayme Azancot e Esther Benefraim, pais de Elias Benafraim Azancot, nascido no ano de 1871, "na ilha de Santo Antão, Cabo Verde"

Embora a identidade dessas mulheres ainda não seja conhecida, assim como o último paradeiro da maioria delas, uma coisa é certa, já sabemos que estiveram por cá e que aqui, ao menos por algum tempo, cuidaram dos seus filhos.

61 Tal como elas, Esther, Mena e Mazaltob, terão chegado a Cabo Verde em companhia dos seus maridos - Abraham Benoliel, Moses Benrós e Jacob Pinto - ou, muito possivelmente, um pouco depois, para servir de suporte à nova vida intentada pelos cabeças-de-casal. Os filhos de Mena, (Isaac Pinto) ${ }^{87}$ e de Mazaltob (Isaac Benrós,1838 ${ }^{88}$, Abraham Benrós, $1844^{89}$, Aarão Benrós, $1853^{90}$ e Esther (?) ${ }^{91}$ ), é provável que, só a menina não tenha vindo de Tânger com os seus pais. Os de Esther, em número de oito, nasceram todos na ilha Boa Vista.

Infelizmente há pouquíssimos registos sobre a vida dessas matriarcas judias, o que fica agravado pela escassez de informações encontradas nas lápides dos jazigos femininos. De Mena e Mazaltob o que se sabe quase que se resume às datas e idades inscritas nos respectivos túmulos. Que Mazaltob nascera Cohen ${ }^{92}$, não nos esclarece, no entanto, da pertença ou não à família dos Cohen estabelecida em Santo Antão, proveniente de Mogador. Dúvida, aliás, que também subsiste em relação à Esther Brigham, igualmente Cohen, antes de se casar com Ayres Julião Brigham ${ }^{93}$.

Só a respeito de Esther, originalmente Benatar ${ }^{94}$, é que já contamos com um pouco mais de informação. A notícia do seu falecimento, contrariamente ao das outras duas, não só foi anunciada como reportada pelos familiares, no Boletim Oficial de Cabo Verde. É assim que, no "Mapa dos europeus falecidos na Província de Cabo Verde no ano de 1891», o desaparecimento da matriarca da importante família que permaneceria, para sempre, associada à ilha da Boa Vista, iria constar: 
Esther Benholiel

filiação: ignora-se

naturalidade: Marrocos

ocupação:

data de óbito: 06 de fevereiro

moléstia: cancro

local do falecimento: ilha da Boavista ${ }^{95}$

Túmulo de Esther Benatar Benoliel ${ }^{96}$

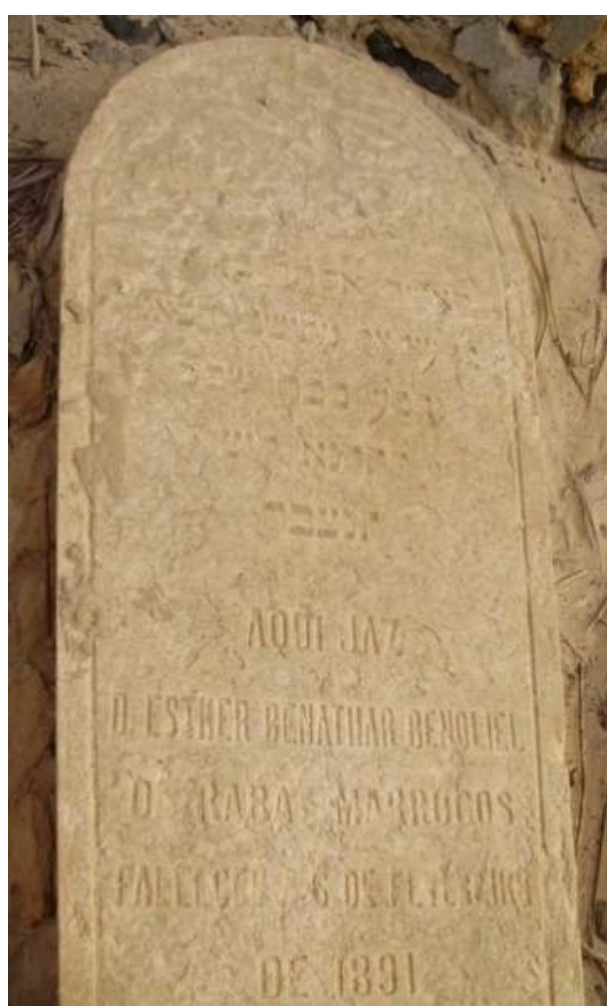

http://www.barrosbrito.com/8774.html

Segue, em nome do marido e filhos da malograda, a nota de agradecimento pelos cuidados dispensados à Esther durante a doença que conduziu à sua morte:

Agradecimento

Abraham Benholiel, Leão Benholiel, Simy Benholiel, José Benholiel, David Benholiel, Salomão Benholiel (ausente), Rachel Benholiel, Simão Benholiel e Maria Benholiel, altamente penhorados pela maneira agradável e desinteressada com que os Exmos. Srs. Bernardo José d'Oliveira, João Augusto Martins, José António Ramalho Pinto do Rosário e João Antonio Valeriano Coutinho se dignaram tratar a sua sempre chorada esposa e mãe D. Esther Benholiel que Deus foi servido chamar ao seu Santo Reino da Glória no dia 6 do corrente, após um longo sofrimento, vêm por este meio patentear a sua eterna gratidão e reconhecimento. Boavista, 9 de fevereiro, de $1891^{97}$.

Esther e Abraham Benoliel eram naturais de Rabat, assim como Rafael Benatar, presumivelmente irmão de Esther ${ }^{98}$. No seu histórico fica a lembrança de, no ano de 1879, tanto ela como o seu cunhado constarem da relação das pessoas que contribuíram para a edificação da igreja matriz da cidade da Praia. A oferta de Esther foi de $2 \$ 350$ réis e a de Isaac Benoliel $\$ 600$ réis $^{99}$. 
Ainda, sobre essas três mulheres, será útil lembrar que Mena Pinto foi a única a conseguir, no seio da comunidade hebraica estabelecida em Santo Antão, um casamento absolutamente judaico para o seu filho Isaac.

\section{Com os olhos nos números e legados dos testamentos}

67 Ângela Benoliel Coutinho afirma que: "Para além de Arão Ben-David e Marcos Bendaham, no século XIX há registo da presença de 14 comerciantes judeus na ilha Brava" ${ }^{100}$, o que não significa terem todos os 16 ali estado, em simultâneo. O próprio Arão Ben-David, natural de Mogador, é indicado pela autora como tendo ido residir nessa ilha, somente em 1870, depois de um certo número de anos a viver na cidade da Praia, de onde "viajava com alguma frequência até lá"101. Se é certo que as ilhas Brava e de São Nicolau estão entre as que, inicialmente, despertaram maior interesse para a emigração judaica do séc. XIX, nada faz crer que em alguma delas se tenha chegado a constituir um grupo significativo, sob o ponto de vista numérico e cultural.

Um pouco diferente será o caso das ilhas de Santiago e de São Vicente, cuja presença desses hebreus é fortemente notada no séc. XIX e inícios do XX. Apontando São Vicente como "a segunda que recebeu um maior número de comerciantes judeus, a seguir a Santiago"102, Ângela conseguiu identificar 21 hebreus "que residiram nesta ilha" ${ }^{103}$. Em Santiago teriam sido ainda mais, assentados, sobretudo, na Praia ${ }^{104}$, onde aportavam e se instalavam antes de qualquer outra acomodação, mas também em Santa Catarina ${ }^{105} \mathrm{e}$ no Tarrafal ${ }^{106}$. Mas aqui, na ilha principal, apesar de contarmos, em determinados intervalos de tempo, com um número bastante expressivo para as circunstâncias, não se chegou também a formar uma comunidade culturalmente desenvolvida. Uma das possíveis razões para que isto não tenha ocorrido é o fato de muitos desses judeus fazerem de Santiago uma base de circulação pelo arquipélago, comprometendo uma relação mais estável com o espaço, pelas frequentes ausências da capital, pautadas por diferentes agendas de negócio.

Ilha de Santo Antão, 1872. Serão estes, o sítio e o momento a serem retidos como a imagem mais expressiva da colónia hebraica em Cabo Verde. Por essa altura, num tempo, é certo, que não terá sido muito longo e numa área do arquipélago também circunscrita, pelo menos ao nível de ritos e cerimónias possíveis, a prática do judaísmo foi uma realidade nessas ilhas.

70 A imigração significativa para Santo Antão, marcada pela chegada de um grupo de 11 hebreus nessa ilha, num processo sobre o qual pouco se conhece, deu-se cerca de uma década antes ${ }^{107}$. Eram quase uma dúzia de hebreus a reunir-se com outros cinco que, desde 1842 , foram chegando nessa ilha um a um e descontinuadamente ${ }^{108}$. Depois da formação dessa comunidade, foram registados, até 1873, a entrada mais 12 , mas quase sempre como no ritmo anterior à vinda dos 11 . A não ser um pequeno reanimo, ocorrido entre 1865 e 1866, com o acolhimento de mais 4 e mais 3, respectivamente, a média de entrada anual até inícios dos anos 70 não foi muito mais do que uma pessoa por ano ${ }^{109}$. Mesmo assim, apesar da não exuberância dos números em termos absolutos, não se poderá nunca dizer que, a nível da Província, a quantidade de hebreus reunidos em Santo Antão, tenha sido despicienda. 
71 Esses e outros dados demográficos relevantes acerca dessa comunidade podem ser hoje conhecidos, graças, sobretudo, aos notáveis Relatórios do «Serviço da Junta de Saúde na ilha de Santo Antão», apresentados pelo dr. Francisco Frederico Hopffer.

Vejamos, primeiramente, como é que, no contexto religioso global, o mesmo distingue a identidade do grupo:

(...) Todos são nominalmente católicos romanos, exceptuando uma colónia hebraica composta por uns 40 israelitas, pela maior parte oriunda de Tânger e Gibraltar, que estão de raiz nesta ilha ${ }^{110}$.

73 Tal constatação, alusiva ao ano de 1871, iria ser actualizada nos Relatórios posteriores, com dados ainda mais robustos acerca dessa comunidade. Afirma o exímio facultativo da província haver na ilha de Santo Antão 12 pessoas a professar a religião mosaica. Doze, sobre um grupo muito maior que, embora oscilante, segundo a radiografia apresentada, terá atingido o seu pico em 1872:

A colónia israelita [acusava, ele,] contava, no ano de 1872, 54 hebreus; e em 1873

baixou a $46^{111}$.

Indica o Relatório de 1873, quanto ao sexo e naturalidade desses hebreus, tratarem-se 27 homens e 19 mulheres: 3 do Reino, 9 de Gibraltar, 16 de Marrocos e 18 "israelitas indígenas" ${ }^{112}$.

Pelo menos por essa altura, por já disporem do minian ${ }^{113}$, os cultos poderiam ser praticados na ilha de Santo Antão, com o requisito exigido. A ausência de uma estrutura própria para a sua realização, não era, de fato, um empecilho, pois nada obstava que os serviços religiosos pudessem ser feitos em suas casas, desde que "reunindo nelas o minian"114.

76 Ao que tudo indica, em nenhum outro lugar do arquipélago esse quórum terá sido alcançado, não sendo exagero admitir que jamais se esteve tão perto, como em Santo Antão, da possibilidade de consolidação de uma comunidade hebraica em Cabo Verde.

No Relatório relativo ao ano de 1874 as informações são novamente actualizadas mas, desta vez, contabilizando-se apenas 7 pessoas votadas à religião hebraica. 0 dr. Hopffer chama atenção para o ritmo evolutivo desse decréscimo: "Vai diminuindo a colonia como se vê dos $n^{\circ} \mathrm{s} 54,46$ e 31, correspondentes aos anos de 1872, 1873 e 1874"115. Nesse último ano (1874) o balanço era o seguinte: 18 homens e 13 mulheres; 7 de Gibraltar, 12 de Marrocos e 11 de Santo Antão ${ }^{116}$. Mas a diminuição da comunidade hebraica da Ribeira Grande de Santo Antão não pararia por aí, chegando-se ao ano de 1879 com apenas 15 pessoas, 11 homens e 4 mulheres. Desses, 4 tinham vindo de Gibraltar, 3 de Tânger, 2 de Mogador e 2 de "Marrocos", sendo os 4 restantes já nascidos em Santo Antão ${ }^{117}$. Num espaço de 5 anos o número desses hebreus tinha-se reduzido à metade! Uma tendência igualmente observada no Mindelo, num tempo ligeiramente depois, pelo menos em relação aos originários de Marrocos, já que os gibraltinos, em São Vicente, foram contabilizados como "estrangeiros ingleses"118. Durante o triénio de 1883-1885, a população marroquina residente na ilha ao lado decresceu de 11 para 9 e, depois, para 8 pessoas $^{119}$.

78 O conjunto de dados disponibilizados pelo dr. Francisco Hopffer conduz-nos à justa noção do número máximo de hebreus que se mantiveram reunidos em Cabo Verde, nomeadamente na ilha Santo Antão. São, por isso, de extraordinário interesse. Contudo, se quisermos ir mais além no tocante à religiosidade presente no grupo, convém 
examinar os inventários orfanológicos e/ou testamentos respeitantes a indivíduos dessa comunidade.

Joseph Julião Brigham (ou Joseph de Abraham Brigham), comerciante, de há muito domiciliado em Santo Antão, faleceu a 26 de março de 1907, de tuberculose pulmonar. Tinha 70 anos de idade ${ }^{120}$. Apesar de ser o último a ser sepultado no cemitério hebraico de Penha de França, ocupa o túmulo indicado no croqui com o número 1. Assim como o seu irmão mais velho, Aires Julião Brigham, que também se instalou em Santo Antão, era natural de uma das principais localidades de origem dos hebreus estabelecidos nas ilhas, que hoje leva o nome de Essaouira. No testamento que fez um ano antes de falecer, constam as seguintes declarações:

Declara que é hebreu, natural de Mogador, província de Marrocos, que é filho legítimo de Abraham Julião Brigham e de Semy Abraham Brigham, já falecidos e não tem outros ascendentes vivos. Declara que quer se faça o seu enterro e as suas funções segundo a sua religião hebraica na importância de cem mil reis.

Declara que deixou para se fazer um cifir com o seu ornamento na importância de trezentos mil reis para ser colocado na igreja da terra de sua naturalidade ....que deixa aos pobres de Mogador 50.000 rs, aos pobres e necessitados de Santo Antão, 20.000 reis.... ${ }^{121}$.

Joseph Julião Brigham, que morreu no estado civil de solteiro, estabeleceu como únicos herdeiros os três filhos menores que tivera com três mulheres diferentes: Hortência, Theodoro e Libânia ${ }^{122}$. Assim sendo, deixou nomeado "para seus testamenteiros e tutores dos ditos menores, o seu sobrinho Abraham Julião Brigham em primeiro lugar e em segundo lugar David Jacob Cohen", ambos moradores da vila Maria Pia.

No auto de juramento e declarações, Abraham Julião "prestou juramento segundo o rito de sua religião hebraica". Três dos cinco indivíduos nomeados vogais do Conselho de Família, instituído para tratar das questões relacionadas com a tutoria e proteção dos menores, fizeram o mesmo, denunciando serem todos praticantes da religião hebraica: David Jacob Cohen, Moyses Jacob Cohen e Isaac Pinto. Os Cohen eram também de Mogador, enquanto Isaac Pinto tinha vindo de Tânger. No espólio deixado por Joseph Julião Brigham foram inventariados 14 livros hebraicos, avaliados em 1.400 reis que, posteriormente haveriam de ser arrematados por Moyses Jacob Cohen, num lote com outros bens ${ }^{123}$.

O inventário orfanológico de Joseph Julião Brigham deixa entrever que a cultura religiosa guardada pela comunidade hebraica domiciliada em Santo Antão foi muito para além da perpetuação dos seus corpos em cemitérios privativos, debaixo das tradicionais estruturas tumulares. Os livros, importantes insumos para a manutenção da cultura desses hebreus, afiguravam-se como um suporte essencial para a observância das suas práticas.

Mas provas de judaísmo em Cabo Verde aparecerão com muito mais evidência no testamento do já mencionado sobrinho de José Julião Brigham, feito na cidade de Lisboa, a 18 de outubro de $1934^{124}$. Por coincidência, foi ele também, tal como sucedera ao seu tio, o último a ser enterrado no outro cemitério de Santo Antão: no de Ponta do Sol. 


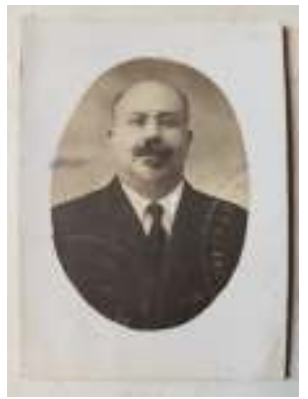

Foto gentilmente cedida pela neta Lucy Rizette Brigham F. Cohen

E assim aconteceu que, estando em tratamento médico na capital portuguesa, e muito provavelmente com algum receio de finar-se por lá, perante o notário do cartório da rua Áurea, n50, compareceu Abraham Julião Brigham,

solteiro, maior, lavrador, morador na vila da Ponta do Sol, da ilha de Santo Antão (...) mas acidentalmente, nesta cidade de Lisboa, (...) E por ele foi dito: Que faz o seu testamento e disposição da sua última vontade pela maneira seguinte. - "Declaro que sou natural da ilha de Santo Antão de Cabo Verde, onde nasci em quinze de dezembro de mil oitocentos e sessenta e quatro, e que sou filho legítimo de Ayres Julião Brigham e sua esposa Esther J. Brigham, já falecidos de longa data. Que professando a religião israelita que era a de meus pais, na qual espero morrer, a dar-se este caso na ilha da minha naturalidade, desejo que se proceda ao meu funeral sem pompa, mas com decoro e simplicidade compatíveis com a minha idade e posição, e de harmonia com a minha crença, organizando-se o meu préstito tanto quanto possível a dentro das normas da mencionada religião e que, depois das abulições do estilo, seja o meu corpo amortalhado com o linho branco que para este efeito tenho uma peça na minha referida residência, e que em seguida se encomende para Lisboa uma loisa de cantaria branca, com a espessura mínima de trinta centímetros, sobre a qual se fará gravar, em hebraico e português, tanto o meu nome como o dos meus ascendentes, bem assim a data do meu nascimento e do meu óbito; - lápide esta que deverá ser colocada sobre a minha sepultura, assim que chegue a Santo Antão. - Se, porém, eu vier a falecer em outra qualquer parte, onde abundem correligionários meus, estes se encarregarão de seguir à risca todos os preceitos do nosso rito. - No entanto, a prevenir a conjectura do caso de vir a verificar nesta cidade, deixo uma carta endereçada ao meu particular amigo e correligionário o senhor Salm Levy, morador na rua dos Retrozeiros, número cento e sete, segundo andar, pedindo-lhe que se encarregue dessa missão, assumindo a sua direção pela forma prescrita na nossa lei, - até as suas mais ínfimas miudências, exigindo dos meus herdeiros, aqui representado pelo meu testamenteiro e filho José, a importância do seu custo" Na sequência do reconhecimento e nomeação dos seus 9 filhos "naturais" enquanto principais herdeiros dos seus bens, e avançar com as partilhas, declara o testador: "Que ao meu filho José lego todos os meus livros de estudo e recreio, à excepção dos de idioma hebraico, os quais fará chegar às mãos do meu aludido amigo Salm Levy, para serem por ele entregues, como oferta minha, à Sinagoga israelita nesta cidade, denominada "Es-haim (...) Que ao meu irmão Marcos lego toda a parte do vestuário que lhe for adaptável. Que à associação de Beneficiência israelita, denominada "Comité Israelita", de Lisboa de "Somej-noflim" e "Ozer-dalim", suas congéneres e sob auspícios da primeira, lego a quantia de mil escudos a cada uma. Que lego bem assim a quantia de quatrocentos escudos para a limpeza e conservação do cemitério que eu for sepultado e mais cem escudos para serem distribuídos em esmolas de cinco escudos pelos pobres mais necessitados da terra e vila da minha residência, no dia do meu óbito ou naquele em que for conhecida a notícia ${ }^{125}$ 
Os casamentos dentro do grupo, promovidos pelos casais de origem hebraica que desejavam manter os seus filhos na mesma cultura religiosa, são, certamente, bons indicadores de preservação identitária. Mas tal como os testamentos, se considerados apenas os casamentos em que pai e mãe de ambos eram hebreus, os relatos não abundam, presumindo-se, até, que tenham sido relativamente poucos. Daqueles de que temos notícia, o mais antigo data de 18 de outubro 1876 e foi realizado na ilha de Santo Antão, sendo os noivos, Moses Abecassis e Simy, originários de Gibraltar e Tânger ${ }^{132}$. certidão de óbito que "faleceu de senilidade-insuficiência cardio-renal" ${ }^{126}$. Tudo indica ter sido enterrado como manda a tradição judaica: envolto em um pano de linho branco, que guardara especialmente para a ocasião. No rol dos inúmeros bens deixados por ele surpreende a quantidade dos livros em hebraico que, por sua determinação, deveriam ser encaminhados à Sinagoga israelita «Es-haim», indicada no testamento: "uma porção de livros hebraicos (setenta e dois), avaliados em 2.500 escudos"! ${ }^{127}$

O testamento denuncia a ligação que Abraham Julião Brigham mantinha com os seus "correligionários" de Lisboa, com os quais podia reunir-se, de tempos, em tempos, para a plena satisfação das necessidades culturais e religiosas. Era na capital portuguesa onde, decerto, lhe era dado nutrir-se espiritualmente e cumprir, com todos os requintes, os rituais mais intensos prescritos pela religião israelita. Por isso, o generoso donativo ao "Comité Israelita", de Lisboa [e], às suas congéneres, a par da oferta do valioso acervo bibliográfico à Sinagoga israelita «Es-haim». Nesta Sinagoga é que, aliás, tinha sido, em 28 de abril de 1924, padrinho de Abraham Ohayon, "filho de Nissim Ohayon e de Donna Benarus Schocron"128.

Abraham Julião Brigham tinha a perfeita noção de ser o último hebreu a viver em Santo Antão. Um hebreu já nado e criado em solo cabo-verdiano. Na ilha onde muitos da sua comunidade se tinham estabelecido mas que para ele, não só era também a sua terra como a de Vitória Maria da Luz, a mulher com quem constituiu família e lhe assegurou uma descendência de 9 filhos: Constança Brigham, Joana Brigham, Julieta Brigham, Alexandrina Brigham, José Andrade Brigham, Maria Vitória Brigham, Matilde Vitória Brigham, Zulmira Vitória Brigham e Margarida Vitória Brigham ${ }^{129}$. Santo Antão era, de fato, a sua terra natal e, por assim entender, mandou reservar, no seu testamento "cem escudos para serem distribuídos em esmolas de cinco escudos pelos pobres mais necessitados da terra e vila da minha residência, no dia do meu óbito ou naquele em que for conhecida a notícia"130. A obrigação para com os pobres era uma prática comum entre os judeus e, por isso, tal como o seu tio Joseph Julião, Abraham Julião Brigham quis deixar uma esmola aos "mais necessitados da terra". Nesse caso, porém, o que certamente há de ter algum significado, o donativo era unicamente para a população carente de Santo Antão e não, como desejou Joseph Abraham, com duplo destino: "aos pobres de Mogador 50.000 rs [e] aos pobres e necessitados de Santo Antão, 20.000 reis"131.

Os testamentos e inventários orfanológicos, sempre ricos
uma mostra de grande interesse para o tema aqui tratado.

\section{A estratégia dos casamentos endogâmicos e 0 suporte dos laços familiares}


Fica-se por saber quem fez e como teria sido a cerimónia. Seria ela filha de algum dos "correligionários" daquela comunidade ou teria vindo para Cabo Verde precisamente para se casar? Quem teriam sido os padrinhos e que conteúdo e ornamentos sustentariam a quetubá133 desse casal? "Tiveram uma filha em Santo Antão e outra e São Vicente" ${ }^{134}$.

Marcos Brigham ${ }^{135}$ com Camila Wahnon, unidos "segundo o rito hebraico" 136 nos aparece como um segundo enlace. O casamento, efetivado a 21 de outubro de 1896, ocorreria em Lisboa, na Sinagoga «Es-Haim» ${ }^{137}$, a mesma a que Abraham Julião Brigham, irmão de Marcos, deixaria, posteriormente, os seus livros em hebraico. "Foram celebrantes deste casamento Moses B. Benchimol e o pai do noivo, e madrinhas as mães dos nubentes" ${ }^{138}$. Contava Camila, nessa altura, com 20 anos e Marcos com 26. 0 casal teve apenas uma filha: Judith Wahnon Brigham, nascida a 26 de novembro de 1897, na ilha de São Nicolau"139. Esta, segundo J. Maria Abecassis, "foi nomeada a 2 de janeiro de 1899 ..., em Lisboa, pelo Rev. Isaac Wolfinsohn, tendo sido seus Padrinhos Jacob Wahnon e Lyce Wahnon"140. A "nomeação", a que se refere o autor da Genealogia Hebraica corresponde à cerimónia religiosa a Simchát Bat, "realizada quando há o nascimento de uma menina judia". "É nesta ocasião que a menina recebe o seu nome judaico e uma bênção especial do rabino"141. Seguindo o costume sefardita de homenagem a um parente vivo ${ }^{142}$, Marcos e Camila, deram à criança, o nome da sua avó materna: Judith.

91 Marcos e Camila pertenciam a duas famílias de grande prestígio em Santo Antão: os Brigham e os Wahnon: uma, oriunda de Mogador, a outra, de Gibraltar. Os pais de Marcos, Ayres Julião Brigham e Esther Cohen Brigham, haviam fixado residência na ilha em inícios dos anos 60 de $1800^{143}$, depois de Ayres ter vivido algum tempo em Santiago ${ }^{144}$. Muito provavelmente terão pertencido ao grupo dos chegados em 1861, mais tarde, portanto, do que Jonas Wahnon (D. João Wahnon), avô da noiva, que em 1856 já se encontrava em Santo Antão ${ }^{145}$. Os tios de Camila, Isaac Wahnon e Raquel [Levy Bentubo] Wahnon ${ }^{146}$, é possível que também tenham feito parte do grupo dos 11 mas, mesmo o casamento destes, supõe-se ter sido realizado (ou consumado) em Cabo Verde. Segundo Ângela Benoliel Coutinho,

James Levy Bentubo, natural de Gibraltar, levou as suas filhas Judith e Raquel para se casarem com dois irmãos Wahnon, seus conterrâneos. Abraham residia em Lisboa e Isaac, em Cabo Verde ${ }^{147}$.

92 A autora terá ainda identificado, no Arquivo Nacional de Gibraltar, "um pedido de passaporte, a 28 de Setembro de 1864, para [Jayme Levy Bentubo] viajar com a sua filha Raquel para Lisboa e para as ilhas de Cabo Verde onde iria casar-se com Isaac Wahnon ou juntar-se ao seu esposo" ${ }^{148}$. Era um casamento (ou melhor, dois) tratado entre "conterrâneos": Jonas Wahnon, pai de Abraham e Isaac e Jayme Levy Bentubo, pai das nubentes, Judith e Raquel.

93 Camila, que nascera em Lisboa, era, portanto, filha de Abraham, irmão de Isaac, que se casara com Judith ${ }^{149}$. O seu avô Jayme Levy Bentubo, cuja presença no arquipélago pode também ser notada "desde o ano de 1856" 150 , (...) terá vivido longos anos em Cabo Verde"151, mais precisamente, na ilha de Santo Antão ${ }^{152}$. Jonas Wahnon e Jayme Levy Bentubo (juntamente com a mulher ${ }^{153}$ ) terão, por conseguinte, antecedido o grupo dos 11. Camila também herdara o nome de sua avó: Camila Bentubo, mulher de Jayme Levy Bentubo ${ }^{154}$.

Os pais de Marcos também já haviam acordado, no seio da comunidade judaica santantonense, um casamento para a sua irmã, Fortunata Brigham. Um ano antes do 
matrimónio de Marcos, Fortunata desposaria Isaac Pinto ${ }^{155}$, único filho de Jacob e Mena J. Pinto. O enlace, efectuado por procuração, deu-se também em Lisboa, onde os Brigham mantinham uma casa em que Fortunata residia na altura ${ }^{156}$. Simão Anahory foi quem representou o noivo. Nessa casa é que, segundo J. M. Abecassis, havia nascido, em 29 de janeiro de 1894, Jacob Brigham Pinto, "circuncidado em 25 de fevereiro de 1895, [...] no largo do Corpo Santo, 6, $2^{\circ}$ [...] por seu avô materno Ayres Julião Brigham, tendo sido seus padrinhos Simão Anahory e Esther Cohen Julião Brigham”. A criança viria a ser legitimada "por subsequente casamento dos seus pais, em Lisboa, a 23 de abril de $1895{ }^{\prime \prime 157}$.

95 Mais tarde, o casal teria mais uma filha: Messina Brigham Pinto, nascida em $1898^{158}$ Registe-se o fato de a circuncisão do filho de Fortunata e Isaac ter sido realizada pelo avô, Ayres Julião Brigham. Estava ele, neste caso, a exercer a função de mohel ${ }^{159}$ mas, um ano depois, como vimos atrás, seria o mesmo Ayres Julião Brigham, juntamente com Moses B. Benchimol, a celebrar o casamento do seu filho Marcos, na Sinagoga «EsHaim» de Lisboa.

A família Pinto, oriunda de Tânger, terá ido residir em Santo Antão em período próximo ou, mesmo, coincidente à instalação dos Brigham. Pais e filho poderão estar, também, entre os 11 hebreus chegados em 1861, pois que, em 1868, Isaac Pinto já fazia parte do grupo dos negociantes influentes dessa ilha ${ }^{160}$. Serels, fundado nos dados de J.M. Abecassis, faz um pequeno histórico dessa família:

Jacob Pinto was born in Tangier in 1830. A Moroccan citizen, he married Mena before moving to Cape Verde. He died in 1894 in Santo Antão. Their son was: Isaac Pinto died in 1921in Santo Antão, Cape Verde. He was a business man who lived in Vila de Dona Maria Pia. He was civilly married to Fortunata Brigham who was born in Santo Antão. She was the daughter of Ayres Julião Brigham and Esther Cohen. Their son was Jacob Brigham Pinto who was later circumcised ${ }^{161}$.

Bidy Auday, provavelmente uma das filhas mais velhas de Marcos Auday e Simy Delmar ${ }^{162}$, desposou um Benchimol. Os pais de Bidy, ele de Tânger e ela de Gibraltar, haviam-se casado em Gibraltar em 1859 e, antes de fixarem residência em Cabo Verde, viveram alguns anos na capital portuguesa ${ }^{163}$. Bidy, nascera em Lisboa. Morreu na Boavista, em 1887, um ano depois do seu presumível jovem irmão, Moses Auday, ter falecido na cidade da Praia ${ }^{164}$. Embora a identidade do marido de Bidy não seja conhecida, a documentação da época faz referência a um certo S. Benchimol, negociante, a circular pelas ilhas no início dos anos 80 do século XIX ${ }^{165}$.

Muitas dessas famílias de origem marroquina e gibraltina, antes de se estabelecerem em Cabo Verde, tinham-se instalado em Portugal, não sendo raros os casos de alguns já terem nascido em solo lusitano. Por conseguinte, os laços e as ligações regulares com a metrópole, sobretudo com a capital portuguesa, mantida por muitos como base principal, foram sempre preservados. Adicionavam-se às motivações de natureza familiar, pois parte dos seus havia permanecido por lá, a necessidade de realização de certos atos civis e religiosos e de efectivação de negócios. A conservação de uma casa em Lisboa era, por isso, de grande valia para as frequentes idas e vindas. Em Lisboa, é possível perceber as relações de proximidade entre essas famílias que, em muitos casos, vinham de trás, sendo mantidas, depois, em Cabo Verde. Jayme Levy Bentubo e Marcos Auday, por exemplo, casaram-se com duas irmãs gibraltinas, da família Delmar: Camila $(1846)^{166}$ e Simy (1859) ${ }^{167}$ e, sendo cunhados, é provável que a decisão de estabelecerem negócios em Cabo Verde e irem para lá viver tenha sido planificada em conjunto. Marcos e Symy Auday foram, aliás, escolhidos para padrinhos de Mary (Meriam) 
Bentubo Wahnon, uma das filhas de Abraham e Judith, irmã de Camila, nomeada em Lisboa em 25.7.1870 168 . As viagens a Lisboa para (ou aproveitadas para) cerimónias do género devem ter sido habituais.

Em dezembro do mesmo ano tanto Marcos como Jayme aparecem em Santo Antão, constando os seus nomes no abaixo-assinado feito pela comunidade judaica da ilha em agradecimento ao médico que havia cuidado do malogrado Fortunato Maman ${ }^{169}$, falecido a 13 de dezembro ${ }^{170}$. Fortunado Maman era, aliás, neto de Joaquim Aflalón ${ }^{171}$, cuja presença nas ilhas remonta aos anos 40 de oitocentos ${ }^{172}$. Entre os nove judeus que assinam o aludido documento podemos ainda encontrar Isaac Pinto que, posteriormente, haveria de se casar com Fortunata Brigham, filha de Ayres Julião e de Esther Brigham ${ }^{173}$. A relação entre os Brigham, os Levy Bentubo e os Wahnon fica também evidente por ter sido Ayres Julião Brigham, coadjuvado pelo avô da criança, Jonas Wahnon, a fazer, em 1873, a circuncisão de Jayme Levy Bentubo Wahnon, um outro filho de Abraham e Judith Wahnon ${ }^{174}$.

100 Ayres Julião Brigham era um mohel experiente e antes de ter circuncidado o seu próprio neto, Jacob Brigham Pinto (1895), presume-se já terem passado pelas suas mãos muitos outros meninos judeus. Dois anos antes de ter efectuado a de Jayme Levy Bentubo Wahnon, havia de ser ele, também, a realizar, em Lisboa, a circuncisão de Saul Cagi (1871). Saul era o sétimo filho de Israel Cagi ${ }^{175}$, um hebreu estabelecido na ilha de Santiago (Praia) desde meados de $800^{176}$, onde chegou a manter, juntamente com o seu tio, a sociedade denominada «Marcos Cagi \& Sobrinho»" ${ }^{177}$. O padrinho escolhido para Saul foi Abraham Azancot ${ }^{178}$, que subscreve também o abaixo-assinado de agradecimento ao médico que assistira Fortunato Maman, antes de este falecer. As relações entre os Cagy e os Azancot revelam-se, ainda, na circunstância de Symy Azancot (presumivelmente mulher de Abrahão) ${ }^{179}$, ser a madrinha de uma outra filha de Israel Cagi, que recebeu também o nome Simy $(1873)^{180}$. Israel Cagi era originário de Tânger, mas todos os quinze filhos que teve com Mary Sefarty, nasceram em Lisboa onde, aliás, havia-se casado. Esther era a mais velha dessa prole e veio a tornar-se, em 1883, a segunda mulher de Raphael Simão Anahory ${ }^{181}$. Ao seu irmão Abrahão Cagi, quinto filho do casal, seria destinada Sophia Zagury, filha do grande comerciante hebreu, nascido em Mogador, Isaac Zagury, estabelecido em São Vicente, no terceiro quartel de $800^{182}$.

101 Mas Jayme Levy Bentubo, como vimos, era também sogro do seu conterrâneo Isaac Wahnon, casado com a sua filha Raquel, assim como do irmão deste, Abraham Wahnon, casado com Judith. Nesse entrelaçamento familiar podemos recuar a Gibraltar e identificar Moses Abecassis como padrinho de dois outros filhos de Jayme: Ledisia Levy Bentubo (1854) e Judah Levy Bentubo (?) ${ }^{183}$. Salomon Levy Bentubo, irmão de Jayme, era, por sua vez, padrinho de Abraham Azulay (1860) ${ }^{184}$. Moses Abecassis e Abraham Azulay também fazem parte da lista de comerciantes hebreus estabelecidos nas ilhas, o primeiro em Santo Antão ${ }^{185}$ e São Vicente ${ }^{186}$ e o segundo, mais ligado à Brava e ao $\mathrm{Fogo}^{187}$. Acrescente-se, ainda, o fato de Jayme Levy Bentubo ter como padrinho Abraham Anahory, avô dos irmãos Anahory instalados em Cabo Verde (13.3.1822) ${ }^{188}$.

Abraham, Salomão, Jayme, Simão e Elias Anahory, netos de Abraham eram filhos de Moysés Anahory e de Mary Mór-José, sendo estes padrinhos do já citado Abraham Wahnon, irmão de Isaac e pai de Camila (18.9.1849) ${ }^{189}$. A ligação particular de Joaquim Aflaló aos Anahory fica patente no apadrinhamento a David Walter Abohbot Anahory, filho mais novo de Jayme (James), circuncidado, em Lisboa, logo após a morte do pai 
$(1877)^{190}$. James Anahory morreu aos 38 anos, em Lisboa $(1877)^{191}$, deixando viúva, com filhos pequenos ${ }^{192}$. Era casado com D. Alegria Abohbot (1867), uma judia também de origem marroquina, nascida nos Açores (ilha Terceira) ${ }^{193}$ e que chegou a viver na ilha de São Vicente com o seu marido ${ }^{194}$. Sabe-se que em 1861, Jayme, juntamente com seu irmão Abraham, tinham tido como destino a ilha de São Vicente ${ }^{195}$ tendo nessa ilha formado uma sociedade comercial com Moses Zagury ${ }^{196}$.

Os cruzamentos, tanto de parentesco como de apadrinhamentos por e de antigas amizades, são inúmeros mas não serão também poucos os encontros e as relações que esses hebreus foram tecendo pelo caminho, até chegarem ou enquanto viveram em Cabo Verde. Não é improvável que os casais de origem marroquina, Abraham e Esther Alves e Fortunato e Vitória Levy, pais Benjamim Alves ${ }^{197}$ e de Bento e Moisés Levy ${ }^{198}$, já tivessem algum contacto no Algarve, de onde partiram para Cabo Verde. Benjamim nascera em Faro (1848) e Bento em Lagos (1851) ${ }^{199}$, sendo o pai e a mãe deste, de Mogador e Maraquexe ${ }^{200}$. Abraham Alves teria, ele também, nascido no Algarve. Em 1859 já estava Cabo Verde e as fontes sugerem que o filho, Benjamim, que aparece na documentação só em $1865^{201}$, teria vindo depois. Os elementos apresentados por Ângela Benoliel Coutinho evidenciam o paralelo da trajectória dos Alves com a dos Levy. Sustenta a autora que: "Foi no ano de 1856 que Fortunato Levy,... de cerca de 40 anos de idade, terá aportado pela primeira vez no arquipélago de Cabo Verde" ${ }^{202}$, e que na década de 1860 a família já estaria instalada na cidade da Praia, onde Bento "foi viver...com os seus pais Fortunato e Vitória"203. Anos depois, Bento Levy se tornaria cunhado de Salomão Anahory, não sendo, no entanto, as duas irmãs, de origem judaica ${ }^{204}$. Os irmãos de ambos estreitariam mais esses laços unindo-se a outras mulheres cabo-verdianas, parentes entre si: Simão Anahory a Engrácia Maria Loff ${ }^{205}$ e Moysés Levy à sobrinha dela, Maria Cecília Loff (Tarrafal de Santiago, 17.6.1888) ${ }^{206}$. Em Cabo Verde, os Levy e os Alves cultivaram uma estreita amizade, o que fica evidente em dois momentos do inventário orfanológico realizado na sequência da morte de Benjamim Alves: na referência feita ao ato de registo tardio de David (1913) ${ }^{207}$, um dos filhos de Benjamim, testemunhado por três dos filhos de Bento Levy "que declararam querer ser padrinhos" $208 \mathrm{e}$ no processo de reconhecimento de Juvêncio, um dos filhos ilegítimos de Benjamim, em que Bento Levy, o seu filho José Levy e mais um familiar com o nome António da Silva Levy são arrolados como testemunha ${ }^{209}$.

Uma atitude interessante observada em Cabo Verde, mas não será só nessas ilhas, é a tentativa de retoma dos casamentos "endogâmicos" por parte de descendentes dos hebreus cujo pai ou a mãe optaram por enlaces fora da comunidade hebraica. Foi o caso de Jayme Monteiro Levy, um dos filhos de Bento Levy e de Paula da Conceição Monteiro. Dos cinco rapazes que tiveram (José Monteiro Levy, Álvaro Monteiro Levy, Jayme Monteiro Levy Fortunato Monteiro Levy e Simão Monteiro Levy) ${ }^{210}$ o terceiro, Jaime, veio a desposar Mary Benoliel, a filha mais nova de Abraham e Esther Benoliel ${ }^{211}$. Entre os Benoliel encontraremos ainda o exemplo de mais um dos filhos de Abraham e Esther, portanto irmão de Mary, a realizar um casamento no quadro da própria família. Salomão Benoliel casou-se com Carolina, filha da sua irmã mais velha, Simy e de António Miguel de Carvalho (Praia, 1913)212. No rol das testemunhas e na cerimónia "bastante íntima" de celebração do casamento de Salomão com Carolina encontram-se, para além de Naturino Alves, Bento Levy e três dos seus filhos: Jayme, que já pertencia a essa família por ter-se casado com Mary, Álvaro e Simão ${ }^{213}$. 


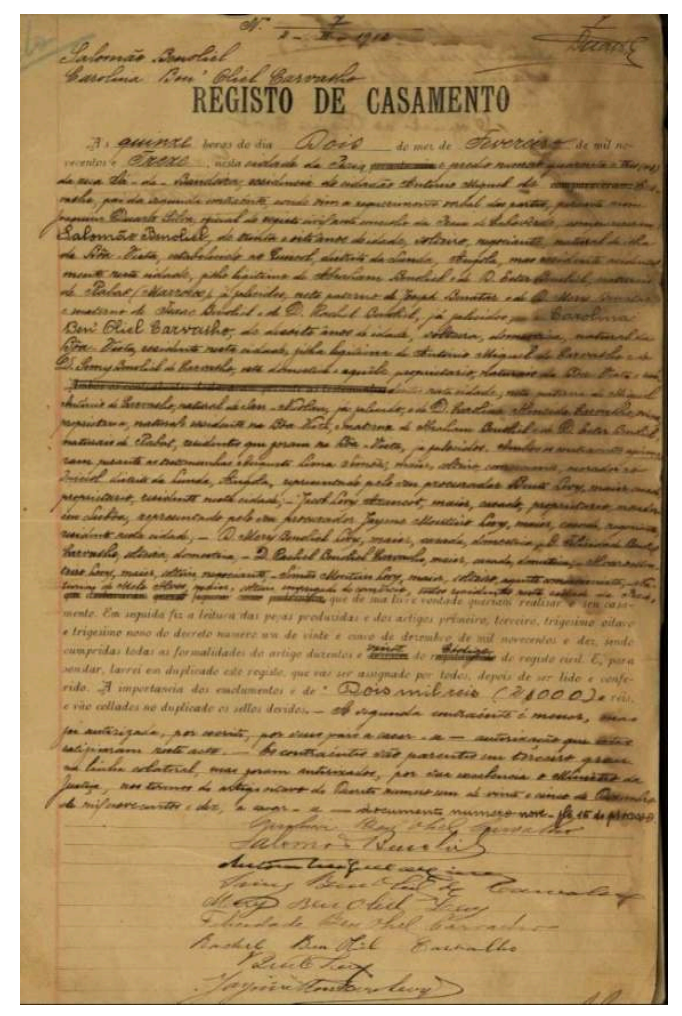

http://www.barrosbrito.com/15292.html

Os Wahnon e os Levy Bentubo juntaram-se a essa família pelos casamentos realizados sobretudo com os filhos de Simy e António: Jacob, um dos filhos de Isaac e Raquel, com Judith Benoliel de Carvalho (Mindelo, 1921) 215 ; Lea Wahnon, também filha de Isaac e Raquel, com Clementino Benoliel de Carvalho ${ }^{216}$ e Carlos Pinto Wahnon, filho de Jaime Wahnon e de Maria da Conceição Pinto, com Alexandrina Benoliel de Carvalho (Mindelo, 1933) ${ }^{217}$. O entrelaçamento do Benoliel com os Wahnon fica evidente. O próprio casamento de Jaime Wahnon com Maria da Conceição Pinto, filha de Isaac Pinto e mãe não judia, insere-se na mesma lógica dos outros atrás referidos. Mas há que invocar, neste caso em particular, a singularidade do ato, por constituir-se no primeiro casamento civil realizado na ilha de São Vicente. $O$ jornal "A Liberdade" não deixou de noticiar a cerimónia ocorrida, no dia 16 de abril de 1902, "com toda a pompa e circunstância" na sala da administração do concelho e no consulado inglês ${ }^{218}$. A matéria subsidia e serve ao articulista para fomentar o caloroso debate que se travava na altura com a Igreja católica, até então, detentora do monopólio da celebração de casamentos $^{219}$. Jayme Wahnon e Maria da Conceição Pinto tiveram quatro filhos, todos nascidos no Mindelo: Raquel Pinto Wahnon (1903) ${ }^{220}$, Isaac Pinto Wahnon (1904) ${ }^{221}$, Carlos Pinto Wahnon (1907) ${ }^{222}$ e Alice Pinto Wahnon (1909) ${ }^{223}$. 


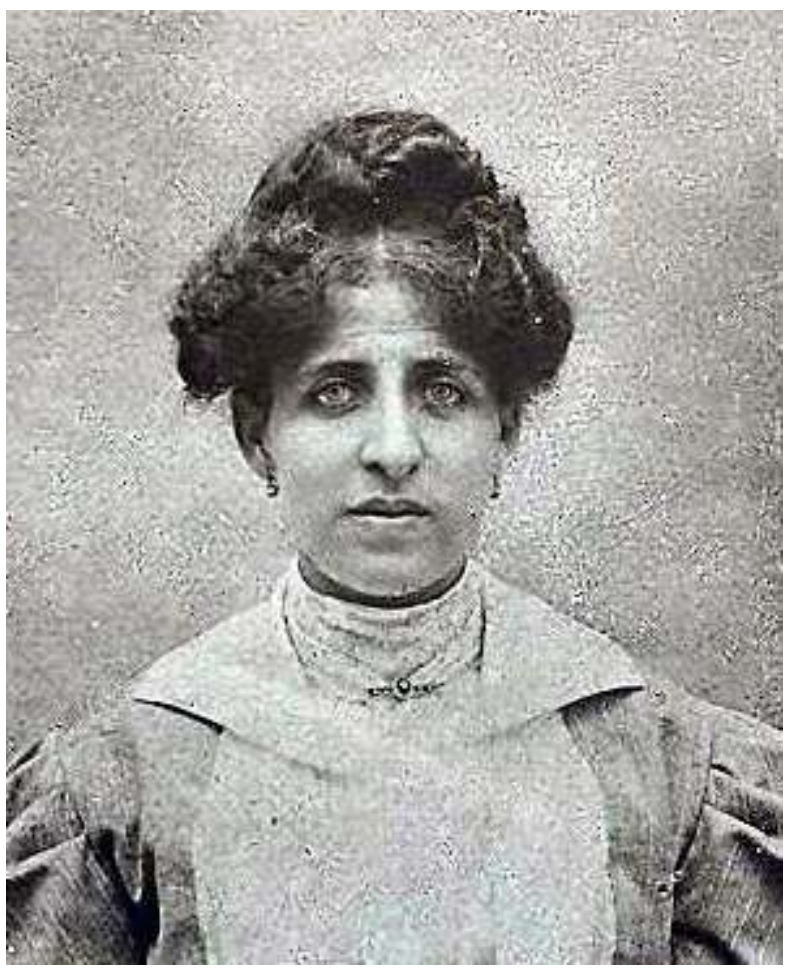

Foto gentilmente cedida por Luis Almeida Santos

No rol dos exemplos desses casamentos ou uniões que se observam na segunda geração estará também o de Isaac Anahory com Julia Azulay ${ }^{224}$. Isaac era filho de Jacob Anahory, originário de Gibraltar ${ }^{225}$, mas ele mesmo nascera em Arzila ${ }^{226}$, possivelmente terra da mãe. Ignora-se o parentesco que teria com os irmãos Anahory, filhos de Moysés. Embora Isaac tenha morrido na Boa Vista, foi na ilha Brava, onde ele e seu pai terão fixado residência nos inícios dos anos 70 de 800, que conheceu Júlia, filha Elias Azulay e Perpétua de Barros ${ }^{227}$. Elias tinha vindo de Túnis e já em 1866 pode ser localizado na ilha Brava ${ }^{228}$. Tiveram quatro filhos: Raphael Azulay Anahory, Maria Anahory, Cândida Anahory e Ana Rosa Anahory ${ }^{229}$.

\section{Os extraordinários casos de conversão ao judaismo}

Todos os sete filhos de Moisés Anahory e de Mary Mór-José nasceram em Lisboa, onde, provavelmente os dois, ele de Gibraltar e ela de Mogador, haviam-se casado. Salomão Anahory, nascido em 1838, foi o segundo filho, sendo Abraham, o primogénito (1835). Atrás de Salomão vieram James (1839), Clara (?), Simão (1847), Elias (1849) e Déborah $(1851)^{230}$. Os cinco irmãos, incluindo Elias, que terá enveredado pela via religiosa (Rev. Elias Anahory) $)^{231}$, assentaram negócios em Cabo Verde ${ }^{232}$.

A notícia de que o armazém que Salomão Anahory possuía na "rua de Alencastre", havia sido roubado no dia 20 de agosto de 1856, atesta que, por essa altura, e ainda muito jovem, o mesmo já se encontrava estabelecido na capital da província. Cerca de uma década depois, estaria ele a solicitar da Câmara municipal o aforamento de um terreno "para servir de cemitério dos israelitas que falecessem nesta cidade" 233 . O objectivo não demorou muito a ser alcançado e, ao fim de alguns anos, a cidade da Praia já podia 
contar com o almejado cemitério. Um "abrigo" que, entretanto, não chegou a lhe valer particularmente já que, depois de viver largos anos em Cabo Verde, Salomão Anahory acabou por morrer em Lisboa, no ano de $1911^{234}$.

Salomão Anahory veio a casar-se com D. Ignes de Barros Monteiro, uma das herdeiras do célebre morgadio dos Mosquitos, estabelecido na ilha de Santiago no ano de 1531. Quatro dos seis filhos do casal nasceram em Cabo $\operatorname{Verde}^{235} \mathrm{e}$, pela data de nascimento da primeira, Mary Monteiro Anahory (1865), estima-se que tal união tenha ocorrido por volta de 1864. O casamento não terá, no entanto, sido da vontade do pai da noiva, Paulo Monteiro dos Mosquitos, que, segundo J.M. Abecassis, "a deserdou"236. Na origem dessa exclusão, há que pensar, logo, no fato de Salomão ser judeu e, nessas circunstâncias, não ser possível um casamento católico senão por via da conversão. $O$ certo é que no apontamento do genealogista, percebe-se ter sido ela a converter-se. Refere-se, pois, Abecassis, não à Ignez mas sim, à "Hannah Ignez Monteiro", como a mulher de Salomão Anahory, o que indica a nomeação da mesma. Mas essa evidência fica ainda mais reforçada quando se sabe que, dos filhos que tiveram para além de Mary - Elias Salomão (1868), Sara (1869), Moysés (1871), Luna (1874) e Abraham Salomão (1875) -, pelo menos os dois últimos, que nasceram em Lisboa, foram submetidos aos rituais judaicos de nascimento. Luna Monteiro Anahory foi "nomeada" a 2 de fevereiro de 1874 "pelo Rev. Moysés Hatchuel tendo sido seus padrinhos seu pai e Rachel Cardozo Anahory", enquanto Abraham Salomão Monteiro Anahory, circuncidado a 6 de maio de 1875, "pelo Rev. Jacob Toledano e Rev. Moysés Hatchuel, tendo sido seu Padrinho Abraham Anahory"237.

110 Não deixa de ser curioso o fato de Clara, uma das citadas irmãs Anahory, já ter, muito antes de Salomão, surpreendido a família pelo casamento contraído, por volta de 1859, com o fidalgo, ele próprio morgado, Sebastião Perestrelo de Vasconcelos. Neste caso, porém, seria ela a converter-se, o que realmente fez, adoptando nome de Maria Eugénia de Souza. Tratou-se, segundo José Maria Abecassis, do «primeiro casamento misto que se realizou em Portugal entre judeus e católicos desde a expulsão, fato que lhe valeu ser votada ao ostracismo pela familia Anahory»" ${ }^{238}$.

111 Mas se Salomão Anahory levou a mulher à conversão, o histórico do irmão, Simão Anahory, revela um procedimento semelhante mas, agora, com relação exclusivamente aos filhos. Raphael Simão ou simplesmente Simão Anahory ${ }^{239}$ teve com Engrácia Maria Loff, uma cabo-verdiana da ilha do Maio ${ }^{240}$, quatro filhos: Moysés de Simão Anahory (Santo Antão, 1874); Mary de Simão Anahory (São Vicente, 1876); Deborah de Simão Anahory (São Vicente, 1878); Raquel de Simão Anahory (São Vicente, 1880) ${ }^{241}$. Deduz-se que a mãe tenha morrido e, nessas circunstâncias, ter Simão Anahory levado os filhos para Lisboa onde, de uma só vez, seria feita a circuncisão de Moysés e as nomeações de Mary, Deborah e Raquel ${ }^{242}$. A cerimónia teve lugar na casa de Salomão Anahory, sita na Rua de São Paulo, 78-4º em Lisboa, no dia 7 de janeiro de 1873. Os tios, Salomão e Hanna Ignes serviram de padrinhos de Moysés que, a partir de então, passou a usar o nome de Raphael de Simão Anahory. Das irmãs, Déborah foi apadrinhada por David e Esther Cagi enquanto Mary e Raquel, por outros membros da família ${ }^{243}$. 


\section{Rafael Simão Anahory}

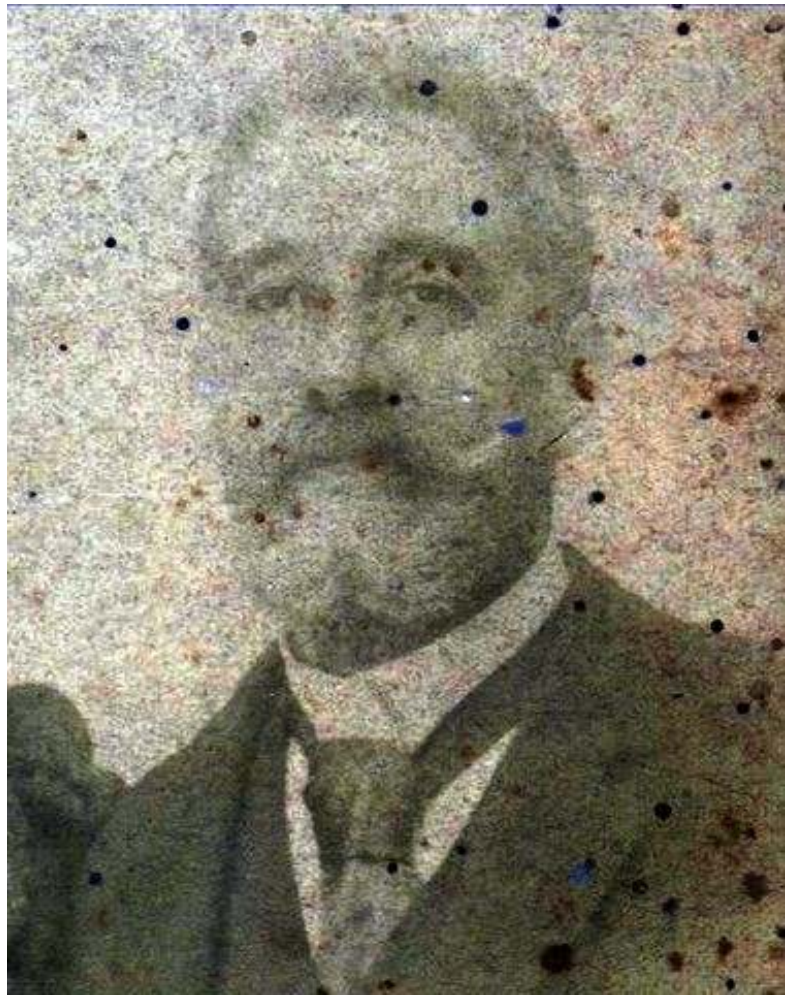

https://www.geni.com/people/Rafael-Simao-Anahory/6000000020435064686

\section{Mary de Simão Anahory}

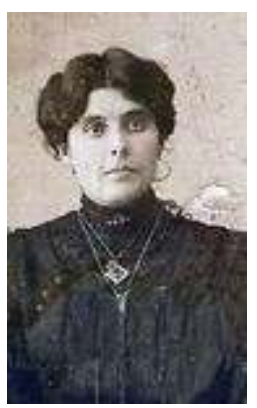

112 https://www.geni.com/people/Mary-Anahory/6000000020435124770

\section{Déborah de Simão Anahory}

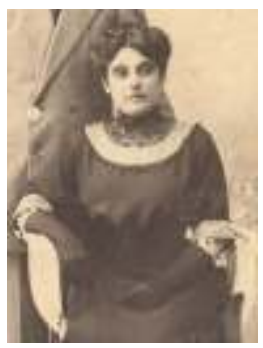

https://www.geni.com/people/Deborah-Brand\%C3\%A3o/6000000020435124774 


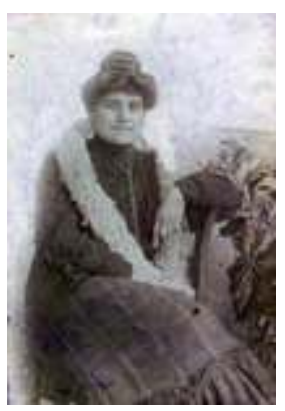

https://www.geni.com/people/Raquel-Pereira-De-Matos/6000000020435124778

O casamento de Simão Anahory com Esther Cagi, com quem teria outros filhos, dar-seia poucos dias depois, mais precisamente a 24 de janeiro de $1883^{244}$.

\section{Na guarda dos sábados...mas dos domingos também?}

114 Os Benoliel que se conservaram, até a segunda geração, fiéis ao culto de enterrarem os seus mortos no cemitério israelita fundado da Boavista, chegando, até, a lutar abertamente por isso aquando do impedimento da inumação de Isaac Benoliel, em 1915, não conseguiram, entretanto, preservar a cultura judaica em todas as suas dimensões.

Os filhos de Abraham e Esther, pelo menos Leão, José, David, Salomão e Simy, para além do mais, frequentaram a escola na ilha da Boavista ${ }^{245}$, não sendo de subestimar tudo o que poderão ter absorvido dessa experiência, enquanto cresciam. Outros meninos de famílias hebraicas, como os Esaguy, que fizeram o primeiro grau ${ }^{246}$ e o Seminário liceu (Isaac Augusto Esaguy), na ilha de São Nicolau ${ }^{247}$ teriam o mesmo percurso, não sendo o impacto sobre estes tão absoluto por, à dada altura, terem ido viver em Faro ${ }^{248}$, onde lograriam reavivar as suas referências culturais mais profundas.

116 A frequência de Simy na escola primária para meninas em 1879 e $1880^{249}$ é, certamente, prova de grande abertura da família Benoliel no que se refere especialmente à educação das filhas. Uma atitude que também se observa entre os Bohanna e os Wahnon. Entre as colegas de Simy que, aliás, foi uma aluna distintíssima, encontramos o nome de Alegria Bohana $^{250}$ (provavelmente filha de Simas Bohana) ${ }^{251}$ e, pela mesma época, em São Vicente, os de Camila Raquel Wahnon e Elisa Raquel Wahnon ${ }^{252}$, filhas de Isaac e de Raquel Wahnon.

Nenhum dos oito descendentes imediatos de Esther e Abraham desposou alguém com idêntica origem e nem mesmo o irmão de Abraham, proveniente como eles de Rabat, absteve-se de escolher uma boavistense para sua mulher. Embora se tenha mantido na religião hebraica, todos os seis filhos que Isaac teve com Guiomar Soares de Brito ${ }^{253}$ Ricardo Benoliel (1866) ${ }^{254}$, Isabel Benoliel (1872) ${ }^{255}$, António Isaac Benoliel (1877) 256 , Maria Benoliel (1880) ${ }^{257}$, Salomão Benoliel (1883) ${ }^{258}$, e José Fernandes Benoliel (1885) ${ }^{259}$ foram baptizados na igreja de Santa Isabel, na Boa Vista. A aproximação da família à comunidade católica parece evidente e algum significado poderá ter o fato de, em 1879, tanto Isaac como a sua cunhada Esther terem feito donativos para a edificação da igreja matriz da cidade da Praia ${ }^{260}$. Tratar-se-ia apenas de um gesto, derivado da usual pressão 
sobre as famílias de comerciantes, habitualmente chamadas a contribuir para as obras do tipo? Ou de alguma real influência da religião dominante sobre a isolada família dos Benoliel? Considerando que na ilha de São Vicente, outros hebreus chegaram a colaborar para o mesmo fim (Zagury \& Cia, 20.000, o próprio I. Zagury, 9\$000, Isaac Wahnon, $1 \$ 500$ e M. H. Abecassis, $1 \$ 500)^{261}$, há que considerar motivações de caráter mais subjectivo a concorrer para essas ofertas.

118 Mas acerca dos casamentos não há o que iludir sobre o peso e predomínio que a contraparte iria ter, particularmente sobre os descendentes, num terreno que lhe era francamente favorável. Mormente sendo ela, e não ele, a detentora da cultura dominante. $\mathrm{O}$ dr. Frederico Hopffer, ao referir-se à comunidade hebraica existente em Santo Antão, pelos anos de 1872-1873, quis pôr, logo, esta questão em evidência: "É preciso dizer [argumentava, ele] que nem todos os filhos naturais dos israelitas são criados na religião do pai se não na que professa a mãe"262.

Praticamente todos filhos de Abraham e Esther Benoliel ${ }^{263}$, optaram por casamentos mistos: Simy, a mais velha, casou-se com António Miguel de Carvalho, oriundo de uma família abastada da Boa Vista ${ }^{264}$; David Benoliel tomou por esposa a irmã do seu cunhado, Maria Isabel de Carvalho ${ }^{265}$, uma mulher extremamente religiosa que ficou associada a construção da Capela de Fátima, empreendida com apoio do marido e "ajuda da população da Boa Vista" ${ }^{266}$; Raquel casou-se com João da Matta Carvalho ${ }^{267}$; Simão, ao que parece, casou-se na Guiné ${ }^{268}$; José, teve duas esposas: Paula da Conceição Mosso e Vicência Mosso, irmã da primeira ${ }^{269}$. 0 passamento de Paula levou a família a emitir a seguinte nota:

\section{Agradecimento}

José Benholiel, Gregório Leitão Mosso, Dorothea Maria Spencer Mosso, Abraham Benholiel, José Spencer Mosso, Vicência Lima Mosso, Domingas Maria Tavares, Ermelinda Maria Spencer, Amélia Spencer Santos, Aurélio Augusto Spencer, António Miguel de Carvalho, Simy Benholiel de Carvalho, Rachel Benholiel e mais pessoas de família, agradecem penhoradíssimos a todos aqueles que se dignaram visitá-los e acompanhá-los durante a doença da sua sempre chorada esposa, filha, genra, irmã, bisneta, sobrinha e cunhada Paula da Conceição Mosso Benholiel e aos que também acompanharam os restos mortais dela à sua última morada $\mathrm{e}$ finalmente a todas as pessoas que por meio de bilhete ou pessoalmente lhes dirigiram pêsames - com especialidade agradecem ao reverendíssimo Padre António Manoel Costa Teixeira pela maneira afável e familiar com que os acompanhou sempre na doença - e pelo zelo e boa vontade manifestada por ocasião dos sufrágios à alma da falecida, e ao enfermeiro reformado Sr. Manoel da Silva Neves, pela prontidão, cuidados e dedicação que sempre mostrou nos curativos da doente. Ilha da Boa Vista, 10 de dezembro de 1893"270.

Só Mary e Salomão é que, de certa forma, poderão ser considerados excepções. Ela, por ter desposado Jaime Monteiro Levy (mas este, já filho de uma cabo-verdiana) e Salomão, a sobrinha, Carolina Benoliel de Carvalho ${ }^{271}$ (cujo pai também não era judeu).

A história dos Wahnon, neste particular, não seria muito diferente da dos Benoliel. Dos treze filhos de Isaac Wahnon e Raquel Levy Bentubo, nenhum se casou com filhos de casais hebreus, observando-se, no entanto, por parte deles (e dos Benoliel), uma reaproximação à comunidade pelo casamento com descendentes de uniões mistas.

Assegurar a identidade pela via dos casamentos em terras tão longínquas, especialmente em ilhas com poucas famílias de mesma origem e com evidentes dificuldades de contacto cotidiano com outros hebreus estabelecidos em outros pontos do arquipélago, era uma aspiração excessiva. Tão excessiva como conseguir alguém que 
instruísse os seus filhos com os parâmetros culturais dos pais. Daí o abandono, em parte, dessas duas componentes estratégicas para a preservação identitária. No campo das uniões afectivas e admissão de casamentos mistos, ao que parece, não houve grande resistência das famílias de origem hebraica estabelecidas em Cabo Verde. E mais facilmente, ainda, poderiam render-se a tais uniões os jovens hebreus chegados às ilhas sozinhos e solteiros, menos sujeitos a pressões familiares adversas. Na verdade, o percurso dos Benoliel e dos Wahnon, em Cabo Verde, não obstante os enlaces atrás referidos, não difere muito da tendência observada em todo o arquipélago das uniões ou casamentos exogâmicos, com parceiros católicos. As tentativas "exitosas", no sentido oposto, foram poucas e quase que circunscritas ao grupo da ilha Santo Antão/ São Vicente. Mas mesmo nesses casos, o que se pode notar é que os casamentos não terão perdurado: Isaac Pinto acabou por divorciar-se de Fortunata Brigham ${ }^{272} \mathrm{e}$ Camila Wahnon, em 1912, já tinha abandonado Marcos Brigham, encontrando-se em parte incerta, e "casada com outro homem" 273. 0 casamento de Maria da Conceição Pinto com Jayme Wahnon não durou dez anos, sendo ela a solicitar o divórcio. Assim, os protagonistas do primeiro casamento civil realizado em São Vicente (1902) acabaram, também, por abrir caminho aos divórcios na Província, liberados com a instauração da República. O Boletim Oficial publicou a seguinte notícia:

AÇÃO DE DIVÓRCIO

Por sentença de de 26 de fevereiro último, que transitou, foi julgada procedente e provada a ação de divórcio litigioso requerida por Maria da Conceição Pinto Wahnon professora particular, residente nesta vila da Ponta do Sol, contra seu marido Jayme Wahnon, empregado no comércio, ausente em parte incerta, e autorizado o respectivo divórcio para os devidos efeitos e nos termos do art $^{\circ} 19$ do decreto com força de lei de 3 de dezembro de 1910. Ponta do Sol, 15 de março de1912 274 .

O que se constata é que também em Santo Antão, acabaram por prevalecer os casamentos ou as uniões realizadas fora da comunidade. O filho mais velho de Moses e Mazaltob Benrós, Isaac, seguiu por esse caminho. Constituiu família com a santantonense Gertrudes Felicidade Silva ${ }^{275}$, com quem teve, pelo menos, oito filhos: Felicidade da Silva Benrós (1863) ${ }^{276}$, Celeste Benrós (1879) ${ }^{277}$, Afonso Benrós, Leão Benrós, Inês Benrós, Júlia Benrós, Maria da Piedade Benrós e Carlota Benrós ${ }^{278}$.

No cômputo geral, tanto os casamentos como as uniões "de fato", são muitos, o que é possível confirmar nos mais casos aqui elencados: Moisés Levy, casado primeiramente com Ermelinda Évora, natural de Lisboa e, a seguir, com a maiense Maria Cecília Loff ${ }^{279}$, depois de enviuvar-se pela segunda vez, desposou Serafina Gomes de Barros ${ }^{280}$; Bento Levy, casado com Paula da Conceição Monteiro; Benjamim Alves com Emília de Melo (1881 ${ }^{281}$; Isaac Seruya com Constança ${ }^{282}$; Elias Azulay com Perpétua de Barros ${ }^{283}$, Simão Benaim com Francisca Rocha Lima ${ }^{284}$, David Azancot com Maria da Conceição Pereira ${ }^{285}$; Abraham Julião Brigham com Vitória Maria da Luz; António Levy Bentubo (filho de Jaime e de Camila Levy Bentubo e já nascido na ilha de Santo Antão, $1863^{286}$ ) casado "conforme o rito da Santa igreja Católica, Apostólica, Romana" com Maria das Dores Monteiro (Mindelo, 1895) 287; Simão Anahory com Engrácia Maria Loff; Salomão Anahory com Ignez de Barros Monteiro (que veio a converte-se ao judaísmo); Joseph Abitbol (José Bento de Oliveira) com Maria das Neves Spencer e, depois, com Rufina de Oliveira ${ }^{288}$.

Numa segunda categoria de uniões distinguem-se os hebreus que, embora já casados com mulheres judias que, por uma razão ou outra não acompanharam os seus maridos, acabaram por fundar uma segunda família em Cabo Verde ${ }^{289}$. Dois exemplos conhecidos 
são os de Jonas Wahnon e de David Jacob Cohen. O primeiro (1812-1895), nascido em Gibraltar, era casado com Meriame Bensid Cohen, de Tetuan, mãe de Isaac, Abraham e mais quatro outros filhos nascidos entre os anos de 1840 e $1849^{290}$. Exceto Abraham, que já nascera em Lisboa, todos os outros eram originários de Gibraltar e Tetuan ${ }^{291}$, o que indica ter Jonas assentado uma base na capital portuguesa onde, aliás, Meriame veio a falecer, em $1889^{292}$. Terá vivido junto aos filhos, entre os quais Abraham, casado com Judith Levy Bentubo, sendo ela, aliás, a madrinha Jacob Bentubo Wahnon, um dos seus netos, circuncidado em $1881^{293}$. Em Cabo Verde, na ilha de Santo Antão, Jonas Wahnon (ou D. João Wahnon) viveu "pelo menos doze anos" 294 com Gertrudes Benvinda Maria de Jesus Ferreira, originária de Setubal, Portugal, com quem teve cinco filhos: Fernando Wahnon (1868), Maria Ernestina Ferreira Wahnon (1873), Veríssimo Wahnon (1875), Jorge Ferreira Wahnon (1878) e Daniel Ferreira Wahnon (?) ${ }^{295}$. Sobre o casamento judaico de David Jacob Cohen, as notícias são mais modestas, apenas que o nome da mulher era Luna e que não teve filhos com ela. Terá ela ficado em Inglaterra (ou Lisboa) de onde se supõe ser originária. Em Santo Antão, David Jacob Cohen viveu continuadamente com Maria das Dores Brito Costa com quem teve oito filhos: Benjamim David Cohen (1882), Nina Cohen (?), José David Cohen (1886), Leão David Cohen (1892), Elisa Cohen (1894), Maria dos Reis Cohen (1896), Daniel David Cohen (?) e Eliseu David Cohen (1898) ${ }^{296}$. Durante o tempo em que estiveram em Cabo Verde terão feito viagens periódicas a Lisboa e Londres, também por motivos comerciais. Depois de muitos anos instalados em Santo Antão e dos filhos já terem tomado pulso nos negócios, Jonas Wahnon e David Jacob Cohen, embora em tempos diferentes, acabaram por abandonar a ilha. Jonas morreu em 1895, em Lisboa, aos 83 anos $^{297}$ e David Jacob em Londres, em 1938, aos 87 anos de idade, vítima de um desastre de automóvel ${ }^{298}$.

Yonah Wahnon (1812-1895)

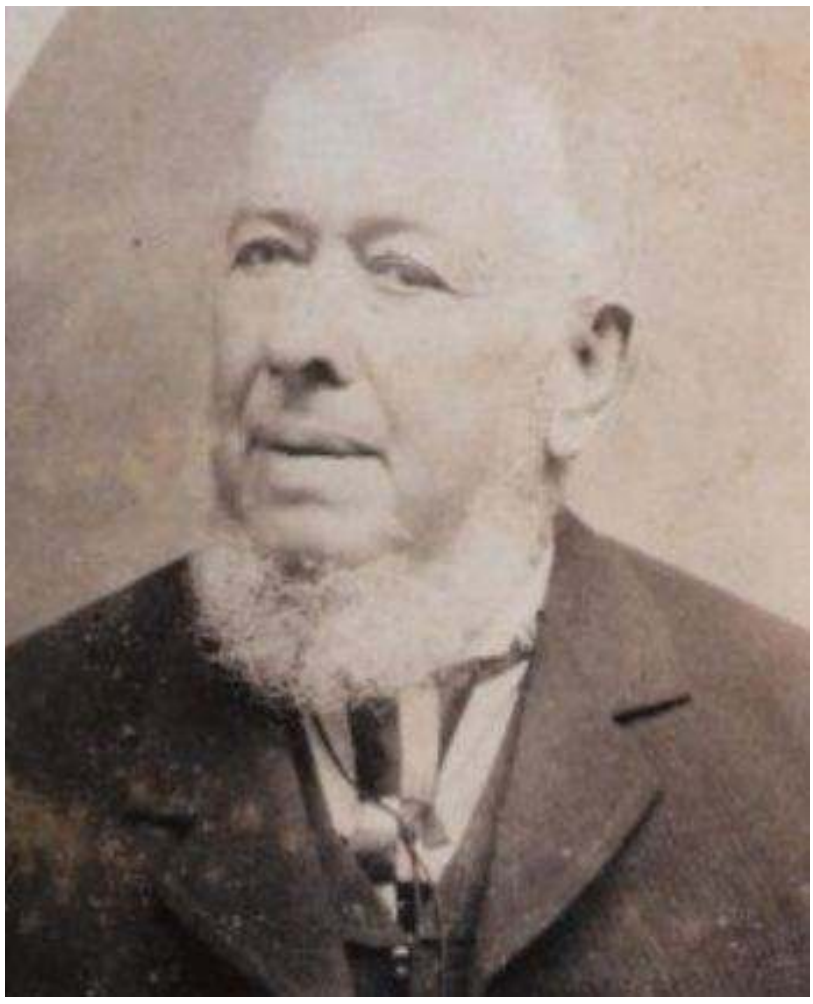

http://www.barrosbrito.com/5444.html 


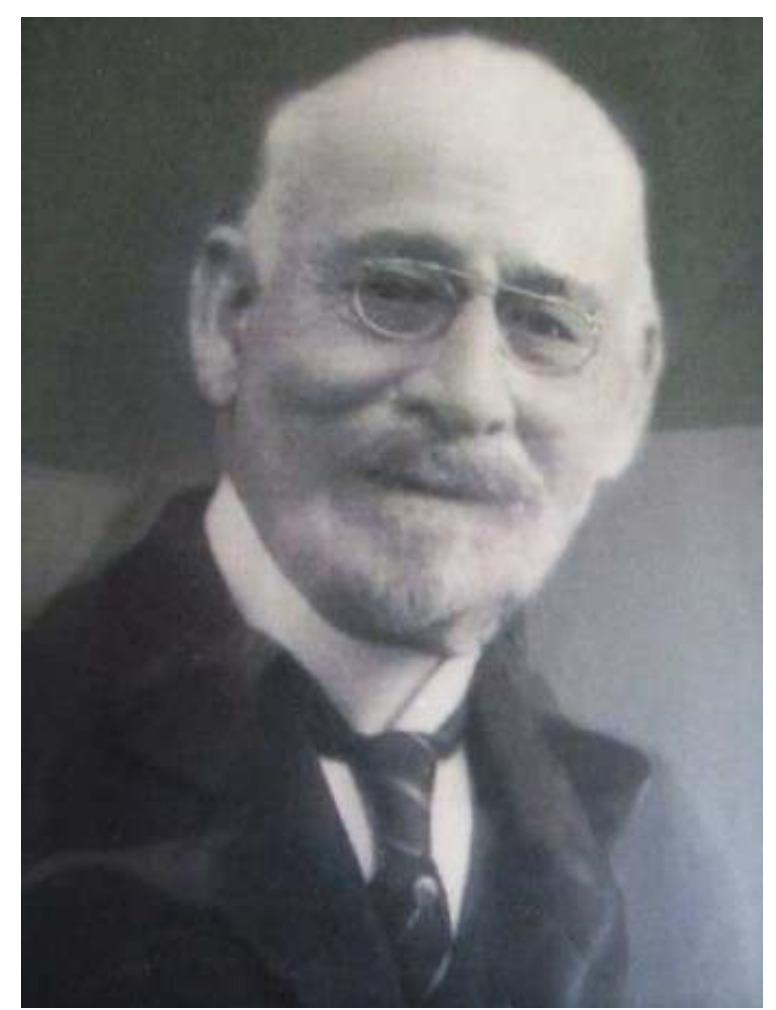

http://www.barrosbrito.com/10473.html

As uniões e os casamentos mistos foram os que, efectivamente, perduraram no tempo e, obviamente, em desfavor da preservação cultura e religião hebraicas. Encontramos de todos os tipos, como dita a própria natureza humana. Mas há que reparar na predisposição desses hebreus para assumirem integralmente os seus filhos, o que inclui aqueles que, ou por já serem casados, ou por não quererem abandonar a sua religião, se mostraram indisponíveis para a formalização das suas uniões em termos matrimoniais. Os filhos desses, tal como daqueles que optaram por um casamento católico, não foram só herdeiros dos seus nomes e do património que conseguiram construir em Cabo Verde. Foram também objecto de investimentos educacionais e das vantagens sociais daí advenientes.

$\mathrm{Na}$ opção de um casamento oficial "face" à igreja católica, a conversão era uma exigência, o que podia ser alcançado pelo baptismo, devidamente autorizado pelo Bispo de Cabo Verde. Foi o caso de Bento Levy, chegado a Cabo Verde com 18 anos, para juntar-se aos pais ${ }^{299}$. Passada uma década, encontrar-se-ia na freguesia de São Nicolau Tolentino, em São Domingos, a casar-se com D. Paula de Conceição Monteiro. Mas, não sem antes de ser baptizado. Vejamos o documento:

Bento Levy, filho de Fortunato Levy e Vitória Levy - Aos sete dias do mês de julho do ano de mil oitocentos e setenta e nove nesta paroquial Igreja de São Nicolau Tolentino do Concelho da cidade da Praia desta ilha de Santiago e Diocese de Cabo Verde solenemente o Reverendo Pároco da freguesia de Santa Catarina desta ilha José Duarte, autorizado pelo Excelentíssimo e Reverendíssimo Senhor Bispo desta Diocese em sua Provisão de oito do mês de maio do presente ano, baptizasse a um indivíduo de sexo masculino com o nome de Bento (Levy por apelido) depois de feita a protestação da fé da nossa Santa, e Apostólica Religião; a qual Bento às 
quatro horas de tarde nasceu de onze de novembro do ano de mil oitocentos e cinquenta e um nasceu em Algarves do Reino de Portugal; filho de Fortunato Levy, negociante, e Vitória Levy, naturais de Marrocos: neto paterno de Bento Levy e Míshóda (?) Levy, e materno de Moysés Levy, e Hamanán (?) Levy, naturais todos do mesmo Marrocos: foi seu padrinho, Pedro Semedo Cardoso proprietário, morador no sítio de Braço (?) desta freguesia, e madrinha a Coroa de Nossa Senhora da Conceição, apresentada pelo António Pedro Silves Ferreira, empregado público, morador em Ribeira Grande da freguesia de São Lourenço deste dito Concelho: sendo o dito Bento Levy e seus pais residentes na dita Cidade da Praia cuja declaração me foi dada pelo mesmo baptizado. E para constar lavrei em duplicado este assento que depois de ser lido e conferido perante eles, e o assinaram comigo. Era ut supra. O Pároco, Pedro Rodrigues Soares; o Vigário José Duarte; Pedro Semedo Cardoso; Bento Levy; António Pedro Silves Ferreira ${ }^{300}$.

Com o irmão Moysés, terá acontecido o mesmo, segundo se pode depreender do assento do seu segundo casamento, no qual se atesta terem os nubentes apresentado os "papéis" necessários, estando, portanto, "sem impedimento algum canónico civil para o casamento":

Moysés Levi, viúvo de Ermelinda Evora e Maria Cecilia Loff - Aos dezessete dias do mês de junho do ano de mil oitocentos e oitenta e oito, nesta Igreja Paroquial de Santo Amaro Abade da ilha de Santiago, Concelho de Santa Catarina, Diocese de Cabo Verde na minha presença compareceram os nubentes Moysés Levy, e Maria Cecília Loff, os quais sei serem os próprios, com os pa[pé]is do estilo correntes e sem impedimento algum canónico ou civil para o casamento, como consta do mandado do respectivo vigário foraneo deste distrito; ele de idade de trinta anos, viúvo que ficou de Ermelinda Évora, natural de Lisboa, comerciante estabelecido no porto do Mangue, filho legítimo de Fortunato Levi e D. Victória Levi; ela, solteira, de idade de vinte e oito anos, natural da ilha do Maio e residente na povoação do Mangue desta freguesia, filha legítima de José Maria Loff já falecido e D. Maria Léger Loff: os quais nubentes, se receberam por marido e mulher e os uni em matrimónio procedendo em todo este acto conforme o rito da Santa Madre Igreja Católica e Apostólica Romana. Foram testemunhas presentes que sei serem os próprios, António Lopes Corrêa, tesoreiro, e Manuel da Luz Gomes Corrêa, solteiro, lavrador, residente nesta freguesia. Para constar mandei lavrar em duplicado o presente termo que, depois de ser lido e conferido perante os nubentes e testemunhas presentes, com estes e o nubente assino. Moysés Levy, António Lopes Corrêa, Manuel da Luz Lopes Corrêa, o vigário João da Cruz Silva"301.

129 Benjamim Alves, filho do casal marroquino Abraham e Esther Alves, é um outro exemplo. Era, como Bento Levy, originário do Algarve. Para se casar com Emília de Melo, Benjamim Alves teve também de converter-se pelo baptismo. Deste ato, ficaria lavrado o seguinte documento:

Aos vinte e oito dias do mês de março de mil oitocentos e oitenta e um, nesta paroquial igreja de São Lourenço_da ilha de São Thiago de Cabo Verde, concelho da cidade da Praia, batizei solenemente e pus os santos óleos a Benjamim Alves, que pertencia à religião hebraica, natural da cidade de Faro, no Algarve, de trinta e três anos de idade, e filho de Habraham Alves e de Dona Esther Alves, aquele falecido, e esta emigrante no Pará, Brasil, sendo o batizando residente em São Thiago, e tendo nascido a oito de março de mil oitocentos e quarenta e oito. 0 mesmo batizando me deu os esclarecimentos. Forão padrinhos João Carlos Vieira, casado, proprietário, e sua esposa Dona Maria da Costa Monteiro, moradores nesta freguesia, no sítio de Vargem da Igreja, os quais como o batizando, assinaram comigo este termo que fiz em duplicado. Assinando-o depois de lido e conferido perante todos. 0 Chantre Manuel Fernando d'Aguiar, Benjamim Alves, João Carlos Vieira" ${ }^{302}$.

130 Benjamim Alves morreu no hospital da cidade da Praia, aos 70 anos de idade (1. 12.918 $)^{303}$. O património deixado por esse judeu convertido mas que descansa em jazigo 
hebraico, foi herdado pela esposa ${ }^{304}$ e pelos dez filhos que deixou: os legítimos: Naturino (1881), Alexandre (1883), Malvina (1884), David (1888), Otaviano (1892) e Mário (1897), e os tidos de outras mulheres, antes e durante o casamento (ilegítimos mas reconhecidos ${ }^{305}$ ): Juvêncio Varela Alves (1872), filho de Martinha Varela, Ivo Alves (1907) e Odin Alves (1909), filhos de Cidália Costa e Edwino Alves (1914), filho de Joana Paula Galina. O nome foi partilhado por todos, abrindo caminho para a enorme descendência dos Alves espalhada, sobretudo, pelo interior de Santiago (Santa Catarina), onde Benjamim tinha vivido a maior parte do tempo ${ }^{306}$.

o percurso de Joseph Abitbol, a quem se atribui a primazia de ter sido dos primeiros hebreus a estabelecer-se em Cabo Verde nessa fase, é um pouco diferente. Instalado em São Nicolau ${ }^{307}$, onde foi "proprietário de casas na vila da Ribeira Brava" ${ }^{308}$, lá viveu até a morte (1880). Joseph Abitbol também ficou conhecido por um outro nome vincadamente cristão: José Bento de Oliveira ${ }^{309}$. Foi nessa ilha que conheceu Maria das Neves Spencer, com quem, entre 1844 e 1862, viria ter alguns filhos: Carlos (1844), Júlio (1851), Júlia (1853), Raphael (1855, +), Ana (1857), Raphael (1861), Francisca (1862) ${ }^{310}$. Todos eles seriam, no entanto, registados como "filhos naturais" de Maria das Neves Spencer, que em outros documentos da mesma época é indicada como "solteira" ${ }^{311}$. O nome do pai é omitido. A partir de fins de 1860, deparamo-nos com o nascimento de outros três filhos de Joseph Abitbol: Salomão (1860), "filho natural de de Rufina Maria d'Oliveira", Maria (1862) e António (1863), sendo esses dois últimos registados como "filha"/ "filho" "natural de Joseph Abitbol, súdito da religião judaica, negociante e Rufina Maria d'oliveira, solteira, moradores na Rua do Calvário desta ilha, neta paterna de António Abitbol e Ana Aires, materna de António Patrício de Oliveira e Maria das Neves"312.

Ora, tanto os filhos de Maria das Neves Spencer como os de Rufina Maria d'Oliveira foram baptizados na igreja matriz de São Nicolau, dando-se inclusive o estranho caso de as duas mulheres serem madrinhas de um dos filhos da outra: Maria das Neves, de Salomão, enquanto Rufina, de Francisca ${ }^{313}$. Os filhos de Maria das Neves Spencer herdaram o nome cristão do pai (Carlos Bento d'Oliveira, Júlio Bento d'oliveira, Júlia Maria d'Oliveira, Ana Maria d'Oliveira, Rafael Moysés d'Oliveira e Francisca Maria d'Oliveira) ${ }^{314}$, assim como a filha de Rufina, que recebeu o nome de Maria Rufina d'oliveira. Somente Salomão e talvez António (que morreu menino) é que teriam herdado o patrónimo Abitbol que, entretanto, não foi transmitido aos descendentes, tornados também Oliveira.

Carlos Bento d'Oliveira

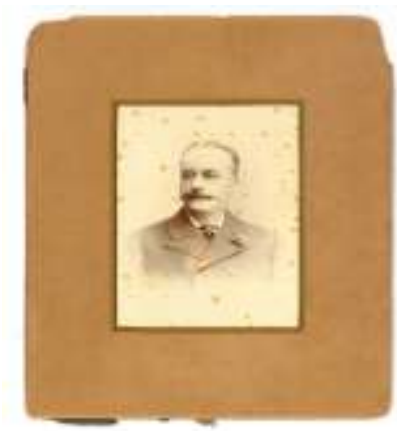

Foto gentilmente cedida por Maria José Oliveira e Silva Saint'Aubyn Mascarenhas 


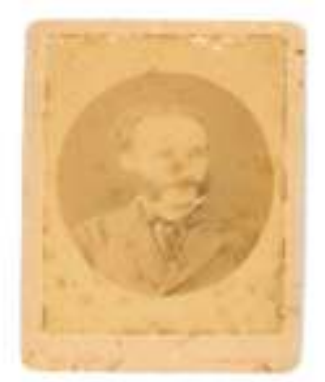

Foto gentilmente cedida por Maria José Oliveira e Silva Saint'Aubyn Mascarenhas

\section{Francisca Maria d'Oliveira}

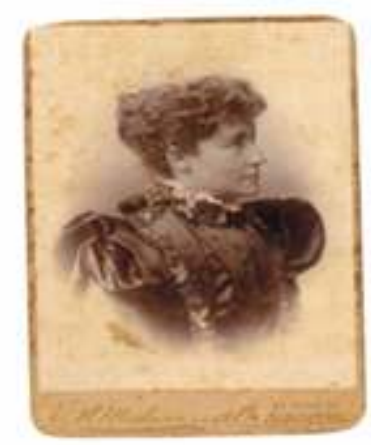

Foto gentilmente cedida por Maria José Oliveira e Silva Saint'Aubyn Mascarenhas

Assim, dissipou-se em Cabo Verde, o patrónimo Abidbol, que não terá sobrevivido muito para além de Salomão. Na verdade, Salomão Joseph como, de fato, aparece na relação do ano lectivo de 1876-1877, ao lado do seu irmão Raphael:

Alunos externos:

Salomão Joseph Abitbôl - estudava latim no primeiro ano, abandonou o estudo.

Raphael Moysés d'Oliveira - aprovado nemine no $2^{\circ}$ ano de francês.

Raphael Moysés d'Oliveira - aprovado nemine no $2^{\circ}$ ano de português ${ }^{315}$.

Observemos novamente o anúncio da morte de Joseph Abitbol, em que é referenciado com o seu nome cristão, mas não os progenitores:

José Bento d'oliveira - súbdito portuguêz, casado, de 64 anos de edade, israelita, natural de Tânger, negociante, residente na ilha de São Nicolau, filho de Hassam Abitebal e Nana Abitebal ${ }^{316}$.

Só há que concluir que também os seus pais, que no registo de nascimento de Maria e António aparecem como António Abitbol e Ana Aires eram, originariamente, Hassam Abitebal e Nana Abitebal. Quer dizer, a família toda tinha adotado um outro nome, muito possivelmente antes do estabelecimento de Joseph Abitbol em São Nicolau. Um acórdão do Conselho de Província, emitido para a resolução de um conflito que envolvia interesses comerciais, esclarece, em parte, a questão do duplo nome utilizado por esse hebreu. Eis a Sentença nº 53, emitida em 26 de maio de 1874:

Acordam os do conselho de província:

Que, tendo-lhe sido presente o requerimento em que Pedro Rodrigues de Castro recorre do acordam da camara municipal do conselho da ilha de São Nicolau, que 
lhe indeferira um outro em que pedira que se intimasse o hebreu José Bento d'oliveira para registar na secretaria da mesma camara a sua carta de naturalização, visto que, por certidão passada pela dita secretaria, consta não se achar ainda registada com tal nome:

Atendendo a que o referido Oliveira tinha apresentado em sessão da camara de 1 d'abril a sua carta de naturalização, sob o nome de Joseph Abitbol, havendo-se reconhecido que ela já ali se achava registada desde 5 de dezembro de 1849; e tendo-se mostrado também que, com quanto fosse esse seu nome de família, ele usara, contudo, sempre do de José Bento d'Oliveira, pelo qual era conhecido antes e depois da naturalização, e tinha servido vários empregos: em vista do que a camara havia indeferido a pretenção do recorrente, baseando-se em que, registada a carta, embora com o nome de Joseph Abitbol, não havia necessidade de novo registo; Atendendo a que, segundo as alegações produzidas por José Bento d'oliveira, e não contestadas pelo recorrente, se prova que o uso deste nome, quando mesmo suposto, datava de mais de 25 anos, e que, por tanto, mal poderia aplicar-se-lhe o art ${ }^{\circ} 226^{\circ}$ do cod. pen. como pretende o recorrente, por isso que, quando existisse criminalidade, não era possível dar ao dito cod. um efeito retroactivo, como se lhe daria indo faze-lo punir um crime praticado muito antes dele ser posto em vigor nesta província (18 de dezembro de 1854);

(...)

Por todas essas considerações, resolvem os do conselho denegar o provimento ao recurso de que se trata, interposto pelo referido Pedro Rodrigues de Castro. Sala das sessões, etc. $=$ Caetano Alexandre d'Almeida e Albuquerque, governador geral, presidente $=$ Balsemão, secretário geral $=$ P.A.M. d'Azevedo, delegado interino $=$ V. J . de Mello = J. P. de Borja ${ }^{317}$.

O acórdão denuncia não só a data em que Joseph Abitbol havia apresentado a sua carta de naturalização na Câmara Municipal de São Nicolau (5 de dezembro de 1849), como ter sido a mesma emitida com este seu nome de nascença. Todavia,

com quanto fosse esse seu nome de família, ele usara, contudo, sempre do de José Bento de Oliveira, pelo qual era conhecido antes e depois da naturalização, e tinha servido vários empregos ${ }^{318}$.

Uma outra evidência é de a utilização do nome cristão por parte de Joseph Abitbol ser anterior ao da sua naturalização e, mesmo, da data em que foi regulada os casos de mudança dos nomes estrangeiros $(1854)^{319}$.

Até onde as pesquisas nos permitem apurar, o que se verifica com Joseph Abitbol, em termos de identificação, não se observa com nenhum dos outros hebreus estabelecidos em Cabo Verde por essa mesma época. Nomeadamente, com Salomão Pimenta, Abraham e Benjamim Alves, Fortunato Cardoso e Isaac Pinto, cujos patrónimos latinos, ao que parece, já estavam consolidados.

Distinto também será do caso dos hebreus que, pelo fato de os seus nomes serem estranhos ou mesmo difíceis de pronunciar na sociedade de acolhimento, acabaram por optar pela sua tradução ou por adotar um outro, de mais fácil assimilação e reconhecimento pelo património onomástico de onde estavam. Por exemplo: Mordechai Auday que ficou conhecido como Marcos Auday ${ }^{320}$, assim como Mordecai Bendaham, também como Marcos ${ }^{321}$, Yonah Wahnon por Jonas Wahnon ${ }^{322}$, Ayres Ohayon Brigham por Ayres Julião Brigham (provavelmente pela sonoridade, é o Ohayon que se transforma em Julião ${ }^{323}$ ) ou Makluf Seruya por José Seruya. Neste último caso, mais difícil de estabelecer a identificação dos nomes na mesma pessoa, a peça-chave para se estabelecer a equivalência foi um anúncio publicado poucos dias depois da morte de Maklouf. Falecido a 9 de julho de 1872, logo, a 20, incumbiu-se o irmão do 
malogrado, grande comerciante da cidade da Praia, de fazer o seguinte comunicado no Boletim Oficial:

Izaac Seruya, extremamente penhorado pelas atenções que se dignaram dispensarlhe e a seu infeliz irmão José Seruya, tanto durante a curta, dolorosa e fatal enfermidade deste, como depois do seu falecimento, acompanhando-o à sua derradeira morada, vem por este meio dar-lhes um público testemunho de gratidão, asseverando-lhes que a lembrança de tão elevadas finezas é o único lenitivo à dor acerba que o oprime. Cidade da Praia, 20 de julho de $1872^{324}$.

\section{A "herança" dos filhos}

Do ponto de vista da descendência desses hebreus importa reconhecer, para além dos frutos das ligações matrimoniais e das uniões estáveis em coabitação permanente, perpetuadores naturais do patrónimo judaico e dos bens familiares constituídos em Cabo Verde, algumas outras situações. Grosso modo, podemos agrupá-las da seguinte forma: a dos filhos perfilhados ou reconhecidos tardiamente; a dos que só foram reconhecidos como herdeiros dos bens e não do nome paterno; a dos filhos que trataram eles próprios de reivindicar a sua filiação, na sequência da morte do progenitor e, por último, e esses serão os mais difíceis de identificar, aqueles que nem nome nem herança receberam. É preciso dizer, no entanto, que todas essas situações reflectem um comportamento comum na sociedade cabo-verdiana daqueles tempos, não sendo, por isso, apenas respeitante ao grupo dos hebreus aqui analisado. Todavia, embora a conta esteja por fazer, é bem possível que, no caso destes, a tendência tenha sido a do reconhecimento da descendência, ainda que esta não estivesse em condições de dar continuidade à essência da identidade paterna.

Na primeira situação encontram-se os herdeiros de Hillel Benchimol, falecido em 1903, no estado civil de solteiro, ab-intestado ${ }^{325}$. Segundo o inventário orfanológico, realizado em 1907, ficaram "os seguintes filhos perfilhados por escritura pública", todos maiores de idade, casados e batizados: Emília Benchimol Semedo (1865), Salomão Tavares Benchimol (1870), Adelina Benchimol Freire (1872) e Ermelinda Benchimol Pinto (1875)...

Que são pois estes quatro os únicos filhos reconhecidos do inventariado, apesar de constar ...ter o inventariado uma natural...casada,...e falecida oito anos antes do inventariado ter reconhecido os quatro indicados por seus filhos, e sem ser reconhecida como filha do inventariado, e da qual ficaram os seguintes filhos supostos netos do inventariado ... António,...Violante,...e mais cinco filhos ${ }^{326}$.

A perfiliação dos quatro filhos, havidos "de uma mulher livre", dar-se-ia a 20 de abril de 1902, portanto, um ano antes morrer ${ }^{327}$. Os filhos que Hillel Benchimol tinha tido com Cândida Tavares Semedo ${ }^{328}$, foram então reconhecidos "para todos os efeitos legais" de modo a permitir-lhes gozar "de todos os direitos e regalias que as leis conferem aos filhos perfilhados", autorizando a todos "a usarem do seu apelido" 329 . Com Juvêncio Varela Alves, filho mais velho de Benjamim Alves, veio a suceder algo parecido. Somente com a morte do pai, e quando já contava com 46 anos de idade, é que, através de uma "investigação de paternidade ilegítima", é que Juvêncio, para efeito de herança, logrou ultrapassar a condição "filho ilegítimo não reconhecido" 330 .

Dos herdeiros apenas dos bens e não do nome, já nos referimos quando tratamos do Inventário orfanológico de Joseph Julião Brigham, falecido na Ribeira Grande de Santo Antão, em 1907, "no estado de solteiro sem ascendentes ou descendentes legítimos [...] 
deixando uma herança de 1.000.000 réis aproximadamente, quasi toda em móveis (fazenda e mais objectos do seu comércio) a qual repartiu por três ou quatro herdeiros estranhos entre si e todos menores, alem de alguns legados." Os "três ou quatro herdeiros estranhos entre si", eram, afinal, três: Hortência Apolónia Gomes, filha de Apolónia Josefa Gomes, Theodoro dos Reis Lopes, filho de Rosa Maria da Luz, e Libânia Maria da Conceição, filha de Joana Maria da Conceição ${ }^{331}$.

Em condição diversa estarão os herdeiros de Salomão Pimenta que, ao que parece, nem trouxe, nem chegou a constituir família em Cabo Verde. Depois da sua morte, em julho de 1866, duas pessoas apresentaram-se como sendo seus filhos. Primeiramente, o patrão-mor da ilha da Brava, Amâncio Júlio de Menezes que, logo em $1^{\circ}$ de outubro do mesmo ano, anunciava publicamente "que pretende habilitar-se como filho e herdeiro de Salomão Pimenta, para todos os efeitos legais" e que, daquele dia em diante, passaria a assinar como "Amâncio Júlio de Menezes Pimenta"332. Um ano depois era Júlio Borges Ferreira a requerer, no Juízo Ordinário do julgado da ilha Brava que fossem posto éditos,

citando e chamando a todas as pessoas que se julgarem com direito à herança de Salomão Pimenta, negociante, falecido na ilha de S. Nicolau desta província", já que o mesmo“ pretende habilitar-se como filho natural e único herdeiro do falecido ${ }^{333}$.

Na história desses hebreus há, por último, que inscrever os inúmeros descendentes que, por circunstâncias várias acabaram por "desaparecer" da linhagem dos progenitores. Ângela Benoliel aponta que, para além dos descendentes que teve da sua esposa Simy Auday, "Marcos teve outros filhos em Cabo Verde, entre os quais Benjamim Nascimento"334, a que podemos acrescentar o nome de José Soares de Brito (1877), nascido da ligação que teve com Maria das Dores Soares de Brito, na ilha da Boa Vista ${ }^{335}$. Afirma a mesma autora que Isaac Pinto "teve outras filhas com mulheres cabo-verdianas que não eram judias" 336. Cláudia Correia, indica o "Sr. Afonso", como "filho ilegítimo de David Benoliel" ${ }^{337}$. Serão mais uns quantos a adicionar nesta lista que há de tornar-se ainda maior se a estendermos aos filhos dos filhos desses hebreus nesta mesma condição. Estudos posteriores, poderão, decerto, contribuir para uma identificação mais perfeita dessa descendência e, quem sabe, até, poder vir a concordar com a afirmação de João António Martins, de que nos finais do século XIX a colónia judaica teria cerca de duzentos membros ${ }^{338}$.

146 Todavia, e apesar de a grande maioria dos filhos não ter reproduzido a cultura do pai, e aqui incluímos mesmo os que puderam privar com o progenitor e conviveram com algumas práticas judaicas no seio de estrutura familiar, o orgulho dessa pertença não se esvaiu de todo. Prova disso é, por exemplo, a opção pela cultura e religião judaica que observamos em alguns já da terceira ou quarta geração. Mas mais simples do que isso, um certo envaidecimento ostentado pelo patrónimo hebraico herdado dos antepassados e que até hoje permanece em Cabo Verde como uma forte referência de pertença.

\section{O abandono de Cabo Verde}

Uma outra circunstância que, pelo seu peso, deve ser devidamente ponderada na questão das práticas do judaísmo em Cabo Verde e da pouca robustez que terá tido para vingar nessas ilhas tem a ver com a não fixação, por gerações, de um número suficiente de hebreus, capaz de assegurar a continuidade dos procedimentos e a própria 
reprodução da comunidade. Por razões que será preciso averiguar, homens e mulheres, ou mesmo casais que para cá vieram tentar a sorte, terão ido embora depois de algum tempo, cancelando projectos de negócios ou mesmo de imigração. Os patrónimos judaicos permanecentes em Cabo Verde indicam que, no conjunto, foram muito poucos os que se deixaram ficar. Ângela Benoliel Coutinho faz o seguinte balanço:

Cerca de uma centena de homens e mulheres terão passado por essas ilhas atlânticas, [...], e cerca de uma vintena constituiu família ou aqui deixou descendentes, identificáveis pelos patronímicos judaicos.... ${ }^{339}$.

Se é certo que alguns não teriam claramente a intensão de ficar, não consistindo as ilhas, para eles, mais do que um ponto para expandir a sua rede de negócios, local de idas e vindas ou de estabelecimento temporário, para outros, sobretudo os que vieram ou viveram acompanhados de suas mulheres e filhos, é muito provável que se tratasse de um projecto planeado de emigração. Entre uns e outros, há que contar, certamente, com aqueles cuja experiência em Cabo Verde acabou por, de um modo ou de outro, ditar a alteração dos planos. Na lista destes últimos talvez possamos inscrever a família Esaguy "que em meados do séc. XIX se instalou em Cabo Verde, emigrando daí para Itacoatiara, no Amazonas, para Faro e Lisboa" ${ }^{340}$. A referência, no caso do Brasil, é feita, concretamente, a Moisés Esaguy que, estando em 1895 já a viver em Itaquatiara ${ }^{341}$, aparece duas décadas antes (1877) em São Nicolau, como subscritor da lista "a favor de vítimas de inundações em Portugal" "342. Para Faro teria seguido, juntamente com a mulher e uma enorme prole nascida em Cabo Verde, o "negociante" A. [Augusto] Esaguy ${ }^{343}$, mas isto, seguramente, não antes de vir à luz a filha Miquelina, na ilha de São Nicolau, a 5 de abril de $1885^{344}$. Essa família, antes de mudar-se para o sul de Portugal, teria vivido, pelo menos duas décadas em Cabo Verde, nomeadamente nas ilhas de Barlavento, Santo Antão, São Nicolau e São Vicente. Tempo bastante e que sugere um projecto de emigração que, ao fim de algum tempo acabou por não resultar.

Poderá ser também os casos individuais de Simy Auday, que "terá ido viver em Marrocos à dada altura" ${ }^{345}$ e de Esther Alves, mãe de Benjamim Alves, que na ocasião do casamento do filho já constava como "emigrante no Pará, Brasil" ${ }^{346}$. Os maridos de ambas ficaram em Cabo Verde, agarrados para sempre a essa terra.

Para o Brasil foram, ainda, Isaac Gabay e família ${ }^{347}$, com mais de uma década a viver em Cabo Verde ${ }^{348}$ e Salomão Moysés Cohen, que poderá ser filho de Moyses Jacob Cohen, sepultado no cemitério judaico de Ponta do Sol. Salomão foi também para a Amazónia (c. 1890), fixando-se junto da comunidade judaica de Parantins ${ }^{349}$, onde fez vida. Jayme Azancot, depois de "estado muitos anos no comércio em Cabo Verde", regressou à Tânger, sua terra natal ${ }^{350}$ e estima-se que com a mulher e filho ${ }^{351}$.

151 A propósito dos hebreus originários de Rabat que acabaram também por abandonar Cabo Verde, Ângela Benoliel Coutinho, chamou atenção para o fato de terem sido muito variáveis os períodos de permanência nas ilhas: Moisés Naure, perto de 30 anos (Brava); Guidon El Caim, talvez mais de 10 anos (Santo Antão), Elias Lasane, provavelmente 2 anos (1866-1868) ${ }^{352}$. De muitos ou, talvez mesmo, da maioria, não se consegue saber o tempo que teriam estado em Cabo Verde, supondo-se terem deixado as ilhas, por mera dedução de os seus nomes não constarem mais dos documentos.

o certo é que a vinda para essas ilhas acabou sendo, para um número bastante significativo desses hebreus, um plano fracassado e a ausência dos que desistiram e abalaram, terá, decerto, feito a diferença na estruturação de uma comunidade portadora de uma cultura de base comum. Nos Relatórios elaborados nos anos 70 de 
oitocentos, o dr. Francisco Hopffer não deixou de chamar atenção para o fenómeno da diminuição de hebreus em Santo Antão, verificado entre 1872 e 1873, "pelo regresso à pátria de antigos residentes e de recém-chegados, que entenderam conveniente retirarem-se" 353 . A diminuição de 54 para 46 não seria ainda grave. Quatro dezenas e meia de hebreus, 27 homens e 19 mulheres, era um número ainda bastante razoável ${ }^{354}$ mas que, entretanto, não deixou de continuar a encolher. Em 1874 os homens do grupo já estavam reduzidos a 18 e as mulheres a $13^{355}$, chegando a 1879 com a 11 e 4 , respectivamente ${ }^{356}$. São Vicente que na década de 80 , contando com os gibraltinos, terá atingido um número com algum significado em termos demográficos, a breve trecho, acabou também por ver regredir a presença judaica na sua população. Os últimos redutos da emigração judaica encontravam-se em evidente declínio. O período áureo dessa presença em Cabo Verde já tinha ficado para trás.

\section{Conclusão}

Sem contar com nenhuma abordagem preliminar, partimos em busca da identificação das práticas culturais judaicas, assim como do grau e intensidade das mesmas. Propusemo-nos verificar se o ambiente em que se davam era suficientemente fértil ou não para que pudessem desenvolver-se e perpetuar-se. O número de judeus estabelecidos em Cabo Verde nesse período, os túmulos e cemitérios por eles erigidos e a designação de «Sinagoga», atribuída a um porto da ilha de Santo Antão, foram os indiciadores dos quais partimos. 0 exame desses elementos revelou-se vantajoso, permitindo-nos, a partir de um conjunto de questões, alcançar práticas como testar, casar, circundar, nomear, comer, etc. que conformaram o quadro de vida dos judeus em Cabo Verde. Pelo exame de actos, ocorrências e circunstâncias cremos ter conseguido levantar um pouco do véu sobre essa realidade.

Deste estudo, pôde-se concluir que:

1. Tal como ocorreu em outras latitudes, os judeus marroquinos e gibraltinos que se estabeleceram em Cabo Verde no séc. XIX, não abandonaram as suas práticas religiosas e que, no arquipélago, as fontes sugerem de estas terem ocorrido em Santo Antão, ilha de maior concentração de hebreus; que o culto decorria em residências particulares e que embora exista nessa ilha um lugar com o nome de «Sinagoga», nada indica que lá tenha sido um local, ou havido um edifício para a realização das cerimónias religiosas do grupo, tratando-se, aliás, de uma designação antiga, referenciada desde, pelo menos, a primeira metade do século XVIII;

2. Muitos dos judeus que vieram para Cabo Verde mantinham uma forte ligação com as sinagogas e comunidade israelita de Lisboa, e as idas à capital portuguesa possibilitavalhes uma inserção/imersão mais profunda na vida social e religiosa da comunidade; não eram incomuns os encontros com os "correligionários" estantes em Portugal e a celebração de atos de cariz civil e religioso;

3. Os testamentos e inventários orfanológicos desses judeus comprovam que a grande maioria deles nunca deixou a sua religião e que mesmo em condições adversas (quando unidos às mulheres cabo-verdianas católicas) permaneciam com as suas crenças e que queriam morrer como judeus;

4. Em algumas ilhas e municípios cabo-verdianos, foi permitido aos judeus a criação de cemitérios privativos ou, quando não, foram-lhes reservados talhões nos cemitérios públicos para enterrarem os seus mortos segundo o ritual judaico. As lápides escritas 
somente em hebraico ou em português e hebraico, que compõem os túmulos, constituem prova de fidelidade à sua religião, língua e cultura; num olhar mais atento sobre a disposição e características das campas judaicas, podemos atestar a observância de determinados preceitos da religião judaica, nomeadamente os que regem as hierarquias entre os sexos, linhagens, idades e circunstâncias da morte.

5. No que à alimentação diz respeito, os hebreus fixados em Cabo Verde lutaram com sucesso para manter as leis de casher nas ilhas onde residissem.

6. Como estratégia de preservação identitária e manutenção da cultura e religião judaicas, utilizaram-se os casamentos dentro da comunidade residente nas ilhas, muito dos quais ajustados entre famílias com laços de amizade e parentesco anteriores à sua fixação em Cabo Verde; não havendo possibilidade da realização de casamentos endogâmicos, entre os filhos dos casais hebreus estabelecidos em Cabo Verde, procuraram-se, em gerações seguintes, uniões entre os descendentes; houve casos de conversão, de mulher e filhos, ao judaísmo.

7. Muito embora o número de mulheres judias vindas para as ilhas ser relevante, as tradições patriarcais do grupo "condenou-as" a uma posição de subalternidade, que se reflecte nas fontes, sobre as oficiais.

8. Não obstante a ocorrência de casamentos endogâmicos, prevaleceram os casamentos ou uniões com mulheres cristãs e esse terá sido um fator essencial da não reprodução da religião hebraica pelos descendentes; alguns hebreus optaram por converter-se, para poderem casar com mulheres cabo-verdianas, ao passo que outros encontraram nas "uniões de fato" a melhor solução; os filhos desses hebreus, nascidos num quadro familiar estável, embora na sua grande maioria não seguisse a religião judaica, foram objecto de investimento social por parte dos pais, constituindo-se em seus herdeiros legítimos, com direito ao nome e ao património material por eles construído.

9. Num quadro familiar menos estável ou mesmo inexistente, esses hebreus tiveram descendentes, nem sempre reconhecidos, encontrando-se nesses casos uma variedade de situações relativamente à filiação.

\section{BIBLIOGRAFIA}

10. O facto de muitos hebreus, sobretudo casais, terem abandonado Cabo Verde ao fim de algum tempo, foi um factor determinante no destino do grupo, que não pôde renovar-se, para a sua manutenção, enquanto uma comunidade distinta.

\section{Fontes manuscritas}

Arquivo Histórico Nacional (AHN), Praia:

Bilhetes de identidade, Praia, ACP-Lv 357, 1945-1950.

Registo Civil da Praia, cx 25, Assentos de Batismos, Freguesia de São Nicolau Tolentino, Peça no 10, 30 maio 1879 - 24 junho 1882. 
Registos Civis da Praia, cx. 63, Assentos de Casamentos, freguesia de Santo Amaro Abade, Peça 1, fevereiro a junho de 1888 .

Tribunal da Praia, cx 342, Autos de Inventário de menores em que é inventariado Hilel Benchimol e inventariante Aureliano Lopes do Livramento, 18 de julho de 1907.

Tribunal da Praia, cx 297, Inventário orfanológico de Benjamim Alves (1918).

Registo Civil de Santo Antão, cx. 29, Assentos de Óbitos, freguesia de Nossa Senhora do Rosário, 01 jan-31 dez 1883, ํㅜㄴ 136.

TRG, cx. 356, Inventário orfanológico de José Julião Brigham (...); Auto de Arrematação.

Registo Civil de São Nicolau, cx 1, Assentos de Batismos, freguesia de Nossa Senhora do Rosário, Peça 1, 06 de novembro de1842 a 03 de agosto de 1852; Peça 2, 11de Setembro de1852 a 20 de março de1864; Peça 310 de abril de1864 a 18 de julho de1866; cx 9, Óbitos Nossa Senhora do Rosário, Peça 46,13 de julho de 1855 a 26 de maio de 1865.

Registo Civil de São Vicente, cx, 14, Assentos de Casamentos, freguesia Nossa Senhora da Luz, Peça 81,10 janeiro1894 - 9 novembro1895.

Registo Civil de São Vicente, cx. 58, Assentos de Casamentos, freguesia de Santa Isabel da Ilha da Boa Vista, Peça 33, 18 de janeiro a 28 de julho de 1900; Peça 31, 3 de janeiro a 21 de dezembro de 1898.

Registo Civil de São Vicente, cx 34, Assentos de Batismos, freguesia de Santa Isabel da ilha da Boa Vista, Peça 2, 9 de abril a 9 de dezembro 1877; Peça 5, 25 de fevereiro de 1881 a 27 de novembro de 1882; Peça 6, 18 de dezembro de 1882 a 24 de dezembro de1883; Peça 8, 01 de janeiro de 1887 a 18 de maio de 1889.

Secretaria Geral do Governo (SGG), cx. 775.

Arquivo da Câmara Municipal da Ribeira Grande de Santo Antão (ACRG):

Administração do Concelho da Ribeira Grande, Registo de Bilhetes de Identidade (diploma Legํㅡํำ 197 de 8 - 5 -1929).

Atas da Câmara da Ribeira Grande 1926-1934.

Autos de Liquidação de contribuição de Registo por título gratuito por óbito de Gertrudes Felicidade Silva Vila da Ribeira Grande (1829-1933).

Repartição da Fazenda do Concelho da Ribeira Grande, Autos de liquidação de contribuição de registo por óbito de Abraham Julião Brigham, morador que foi da vila da Ponta do Sol, do Concelho da Ribeira Grande, Processo nํ 367, de 6 de outubro de 1941.

Arquivo Histórico Ultramarino, Lisboa:

Documentos Avulsos, cx.16.

\section{Fontes online}

http://www.barrosbrito.com/5444.html.

http://www.barrosbrito.com/5946.html.

http://www.barrosbrito.com/7046.html.

http://www.barrosbrito.com/8539.html\#1.

http://www.barrosbrito.com/8611.html. 
http://www.barrosbrito.com/8616.html.

http://www.barrosbrito.com/8539.html.

http://www.barrosbrito.com/8665.html.

http://www.barrosbrito.com/8772.html.

http://www.barrosbrito.com/8773.html.

http://www.barrosbrito.com/8773.html\#2.

http://www.barrosbrito.com/8774.html .

http://www.barrosbrito.com/8893.html\#1.

http://www.barrosbrito.com/8894.html.

http://www.barrosbrito.com/9878.html.

http://www.barrosbrito.com/9879.html.

http://www.barrosbrito.com/10102.html.

http://www.barrosbrito.com/10388.html.

http://www.barrosbrito.com/10390.html.

http://www.barrosbrito.com/10392.html.

http://www.barrosbrito.com/10473.html.

http://www.barrosbrito.com/10957.html.

http://www.barrosbrito.com/10958.html\#1.

http://www.barrosbrito.com/12396.html\#1.

http://www.barrosbrito.com/12399.html.

http://www.barrosbrito.com/13510.html.

http://www.barrosbrito.com/13744.html

http://www.barrosbrito.com/14273.html.

http://www.barrosbrito.com/15157.html.

http://www.barrosbrito.com/15158.html.

http://www.barrosbrito.com/15260.html\#3.

http://www.barrosbrito.com/15292.html

http://www.barrosbrito.com/15400.html

http://www.barrosbrito.com/15839.html.

https://www.familysearch.org/ark:/61903/3:1:3QS7-L974-DHC3.

https://www.geni.com/people/Rafael-Simao-Anahory/6000000020435064686.

https://www.geni.com/people/Mary-Anahory/6000000020435124770.

https://www.geni.com/people/Deborah-Brand\%C3\%A3o/6000000020435124774

https://www.geni.com/people/Raquel-Pereira-De-Matos/6000000020435124778.

https://pt.chabad.org/library/article_cdo/aid/618835/jewish/Brit-Mil-Circunciso.htm 
https://cip.org.br

https://culturahebraica.blogspot.com/2018/03/sepultamento-judeu-por-que-e-proibido.html. https://digitarq.adlra.arquivos.pt/details?id=1297474.

https://www.familysearch.org/ark:/61903/3:1:3Q9M-C95G-BFFG?cc=2246703.

https://perdaseluto.com/2016/08/24/o-significado-da-morte-e-o-processo-de-luto-na-visao-dojudaismo/.

https://todasfunerarias.com.br/tradicoes-e-costumes-no-sepultamento-judaico.

\section{Bibliografia e fontes impressas}

A Liberdade, ํㅡㄴ 4, domingo, 20 de abril de 1902, Suplemento $\mathrm{n}^{\circ} 40$.

ABECASSIS, José Maria, Genealogia Hebraica - Portugal e Gibraltar Sécs. XVII a XX, Edição do autor, 5 vols., Lisboa, 1990/91.

BENCHIMOL, Samuel, Eretz Amazónia - os judeus na Amazónia, Manaus, Valer, 2008.

Boletim do Conselho Ultramarino, Legislação Novíssima, vol. V, Lisboa, Imprensa Nacional, vol. 5, Junho de 1854.

Boletim Oficial da Província de Cabo Verde (B.O.C.V.), nº. 130 (1846); 171 (1847); 169 (1855); 20 (1864); 15 (1865); 44 (1866); 17 (Suplemento), 46 (1867); 11 (1868); 6 (1869); 6, 37 (1871); 17, 30 (1872); 27, 35 (1874); 34 (1875); 35, 41 (1876); 3, 35, 40 (1877); 16, 16 (Suplemento), 17, 27, 36, (1879); 36 (1880); 17, 22, 42 (1881); 19, 20, 37, 38 (1882); 9, 37, 47 (1883); 35, 41 (1884); 34 (1885); 20, 21, 41 (1886); 21, 37 (1887); 8 (1891) 22, 32, 50 (1893), 11, 22, 30 (1894); 32, 33, (1897); 2 (1898); 4 (1906); 14 (1909); 49 (1910); 48 (1911); 12, 47 (1912); 33 (1917); 18 (1919).

COUTINHO, Ângela Sofia Benoliel, “Do Mediterrâneo ao Atlântico: Comerciantes judeus de Marrocos e Gibraltar no arquipélago de Cabo Verde (1860-1900)", in Colóquio Internacional Judeus e Cristãos-Novos no Mundo Lusófono, Lisboa, 2-4 dezembro de 2015, ISCSP - Universidade Técnica de Lisboa, texto gentilmente cedido pela autora.

COUTINHO, Ângela Sofia Benoliel, "Judeus marroquinos e de Gibraltar em Cabo Verde no século XIX" (título provisório), texto gentilmente facultado pela autora, 91 pp. (não publicado), 2015.

CORREIA, Cláudia, Presença de Judeus em Cabo Verde - Investigação na documentação do Arquivo Histórico Nacional (1840-1927), Arquivo Histórico Nacional, Praia, 1998.

CORREIA, Cláudia, “A questão do cemitério israelita na ilha da Boavista (1915-1923)”, Africana Studia 2 (1999), pp. 97-134.

CUNHA, Cláudia et all, "Matzevot kevurah esquecidas - resgate etnoarqueológico do Cemitério Judaico de Gurupá”, Pará, Brasil, Antropologia Portuguesa 36 (2019, vol. 36), p. 145, http://doi.org/ 10.14195/2182-7982_36_7.

Dicionário do Judaismo Português (coordenação de Lúcia Liba Mucznik, José Alberto Rodrigues da Silva Tavim, Esther Mucznik e Elvira de Azevedo Mea), Lisboa, Editorial Presença, 2009.

HELLER, Reginaldo Jonas, Judeus no Eldorado: Reinventando uma identidade em plena Amazónia: a imigração dos judeus marroquinos e do norte da África para o Brasil (Pará e Amazonas) durante o século XIX, e-papers, Rio de Janeiro, 2010.

Notícias de Cabo Verde, ํำ173, 1ํㄹe agosto de1938; nº 179, 15 de Setembro de 1938. 
O Independente, $\mathrm{n}^{\circ}$ 28, 7 de fevereiro,1913.

OLIVEIRA, João Manuel Nobre de, A Imprensa Cabo-Verdiana 1820-1975, Fundação Macau, Direção dos Serviços de Educação e Juventude, 1998.

OLIVEIRA, João Manuel Nobre de, “A presença judaica em Cabo Verde”, Revista de Cultura 35 “Culturas Paralelas e processos transculturais - (julho 2010)” pp. 95-105.

SERELS, M. Mitchell, Jews of Cape Verde: A Brief History, Sepher - Hermon Press, Inc. Brooklyn, NY, 1997.

SOARES, Marco Antonio Neves et all, Túmulos judaicos em cemitérios não-judaicos: uma análise da cultura material, http://eeh2010.anpuh-rs.org.br/resources/anpuhpr/anais/ixencontro/ comunicacao-coordenada/Etnicidade\%20e\%20Morte/MarcoANSoares.htm

WOLFF, Egon e Frieda, Crônicas do nosso Arquivo, IHGB, 1987.

\section{NOTAS}

1. M. Soares et all, Túmulos judaicos em cemitérios não-judaicos: uma análise da cultura material www.snh2013.anpuh.org/resources/anpuhpr/anais/ixencontro/comunicacao - coordenada/ Etnicidade e Morte /

2. A. Coutinho, Judeus marroquinos ....

3. Os túmulos horizontais, característicos dos sefarditas, distinguem-se dos verticais, adoptados pelos asquenazistas (judeus europeus).

4. 0 dogma talmúdico indica "a necessidade de simplicidade e uniformidade nas estruturas funerárias em um cemitério judaico [não sendo] permitidos adornos elaborados ou túmulos sumptuosos [...], de forma a que um não se sobressaia a outro", in C. Cunha et all, "Matzevot kevurah esquecidas".

5. O modelo dos túmulos é o predominante nos cemitérios judaicos do norte no Brasil, entre os quais o de Gurupá, de onde retiramos a descrição, por serem a maioria dos jazigos lá encontrados análogos aos existentes em Cabo Verde. C. Cunha et all, "Matzevot kevurah esquecidas...", p. 156.

6. C. Correia, Presença de Judeus em Cabo Verde ..."; C. Correia, “A questão do cemitério israelita ...", pp. 113-134.

7. A. Coutinho, "Do Mediterrâneo ao Atlântico ...", p.8.

8. Em carta de 6 de abril de 1733, em que o capitão-mor de Santo Antão, Cláudio Roquete da Silva, acusa a vulnerabilidade da ilha face às ameaças de invasão estrangeira, pode-se ler o seguinte: "(...)..tambem podem tomar esta ilha a partir do sitio a que chamam Sinagoga"; A.H U, Documentos Avulsos, cx. 16, doc. 17.

9. Relatório do serviço da delegação da junta de saúde na ilha de Santo Antão, relativo ao ano de 1873, apresentado pelo Dr. Francisco Frederico Hopffer -29 de agosto de1874, B.O.C.V., nº. 35, 1874.

10. O historiador João Nobre de Oliveira chega mesmo a afirmar, peremptoriamente "que nunca houve sequer uma sinagoga construída nas ilhas", in "A presença Judaica em Cabo Verde", p. 104.

11. Ângela Sofia Benoliel Coutinho contabiliza três dezenas e meia de túmulos judaicos "em 4 cemitérios existentes em 3 ilhas de Cabo Verde: Santiago, Santo Antão e Boavista" , in "Do Mediterrâneo ao Atlântico ...", p. 7. A estes, no entanto, será preciso acrescentar muitos mais, dispersos por outros locais e outras ilhas.

12. Na linha do que defende João Nobre de Oliveira (2010), tratar-se-ia de "uma segunda vaga de imigração [judaica nas ilhas], esta de origem norte-africana, com elementos praticantes da sua 
religião e que, desta vez, não sofreram perseguições”, “A presença judaica em Cabo Verde”, p. 100.

13. Portaria de 9 de abril de 1864, in Boletim do Conselho Ultramarino, Legislação Novíssima, vol. V, pp.13-14, cit. por C. Correia, “A questão do cemitério israelita ...”, 1999, p.100.

14. Administração do Concelho da Praia - Circular no 1 para o Físico Mor, A.H.N. \A $\backslash S R: D \backslash 009$ -1854/1857, cit. por C. Correia, Presença de Judeus ..., p. 26.

15. ACRG, Atas - 1926- 1934, Ata da sessão de 11 de dezembro de 1927.

16. B.O.C.V. no 20, 1864; cit. por C. Correia, Presença de Judeus ..., p. 19.

17. Acordam nº 30, B.O.C.V. nº 15, 1865; cit. por C. Correia, “A questão do cemitério israelita ...”, p. 108.

18. J. Abecassis, Genealogia Hebraica ..., vol. I, p. 460.

19. B.O.C.V. 169, 1855.

20. J. Abecassis, Genealogia Hebraica..., vol. II, p. 505.

21. Código de Postura da Câmara municipal do Concelho da Praia, 23 de maio de 1894, Cap. IX Dos Cemitérios, art. 99, B.O.C.V. 22, 1894; cit. por C. Correia, , “A questão do cemitério israelita ...”, p. 108.

22. A mesma informação é confirmada por outro documento relativo a este processo, com data de 27 de setembro: “(...) Anexos ao cemitério público da Praia há dois cemitérios particulares: o dos americanos e o dos hebreus". AHN, Secretaria Geral do Governo (SGG), cx. no 775 .

23. Parecer de 27 de Setembro de 1923, respeitante ao enterramento dos católicos e não católicos no cemitério público da Praia; AHN, SGG, cx. oำ 775.

24. B.O.C.V. $\mathrm{n}^{\circ} 6,1869$.

25. B.O.C.V. no 21,1886 .

26. Croqui gentilmente cedido por Flávio Delgado.

27. https://culturahebraica.blogspot.com/2018/03/sepultamento-judeu-por-que-eproibido.html

28. AHN, Tribunal da Praia, cx 297 (1918), Inventário Orfanológico de Benjamim Alves.

29. C. Cunha et all, "Matzevot kevurah esquecidas...", p. 159.

30. Croqui gentilmente cedido por Flávio Delgado.

31. B.O.C.V. no $45,1868$.

32. "Os Regedores das paróquias eram propostos pelos administradores dos concelhos [...], e nomeados pelos administradores gerais para servirem por um ano. Os regedores eram um elemento muito próximo do poder local. A ele subordinados garantiam a boa aplicação das leis e dos regulamentos administrativos. Exerciam a autoridade policial no território da freguesia.", https://digitarq.adlra.arquivos.pt/details?

id=1297474\#: :text=Os\%20Regedores\%20das\%20par\%C3\%B3quias\%20eram\%20propostos\%20pelos\%20administradores,boa\%20aplica\%C 33. Ângela Sofia Benoliel Coutinho atesta que "Salomão Pimenta viveu na Praia, em S. Nicolau e na Brava, entre 1842 e 1867", “Judeus Marroquinos ...”, p. 39. Manuscrito gentilmente facultado pela autora.

34. João Manuel Nobre de Oliveira, “A presença judaica ...”, 2010, p. 101, afirma, por sua vez, serem Abraham Alves e Joseph Abitbol, que "mudou depois o nome para José Bento de Oliveira", "dos primeiros elementos da comunidade judaica vinda de Marrocos a radicarem-se, definitivamente, nas ilhas", tendo o primeiro se estabelecido na ilha de Santiago (primeira metade do século XIX), residindo o segundo, desde a década de 1840, na ilha de São Nicolau, p. 101.

35. C. Correia, Presença de judeus ..., p. 81.

36. Anúncio de 28 de outubro de 1866, in B.O.C.V. nº 44, 1866.

37. Sinopse da Correspondência expedida pela Secretaria- Geral (1ª Repartição), B.O.C.V. $n^{\circ}$ 130, 1846.

38. "Relação dos europeus falecidos nesta província, e cujas comunicações foram recebidas nesta Secretaria-Geral, desde 11 de Setembro do ano passado [1880] ", B.O.C.V. no 22, 1881. 
39. Código de Posturas da Câmara municipal de Santa Catarina, 28 de junho de 1893, cap X - Dos Cemitérios, secção $1^{\mathrm{a}}$ Dos Covados, art. 89, § único, B.O.C.V. nº 32, 1893.

40. AHN, cx no 342, Tribunal da Praia - Autos de Inventário de menores em que é inventariado Hillel Benchimol e inventariante Aureliano Lopes do Livramento, 18 de julho de 1907.

41. C. Correia, “A presença judaica ...”, 1998, p. 83.

42. Código de Posturas da Câmara municipal do Concelho da ilha de Santo Antão, 5 de junho de 1893, cap. XIII - Cemitério, art. 61, § único; in B.O.C.V. nº 11, 1894; cit. por Cláudia Correia (1999), p. 108.

43. $O$ intuito da Circular era harmonizar a legislação em conflito com relação aos enterramentos. Se por um lado proibiam-se as inumações fora dos cemitérios públicos (onde o terreno era consagrado pelas bênçãos da igreja católica), por outro, tinha de ser respeitado o direito de as pessoas de religião diferente poderem enterrar os seus mortos. Circular $n^{\circ} 59$, de 20 de maio de 1882; in B.O.C.V. $20,1882$.

44. Designação judaica para os 7 primeiros dias de luto.

45. B.O.C.V. $\mathrm{n}^{\circ} 6,1871$.

46. https://perdaseluto.com/2016/08/24/o-significado-da-morte-e-o-processo-de-luto-na-visaodo-judaismo/; A este propósito verifica-se que os "dois túmulos menores nos quais provavelmente foram inumadas crianças [encontrados no cemitério de Guarupá] não apresentam inscrições e é impossível atribuir género aos seus ocupantes." C. Cunha et all, "Matzevot kevurah esquecidas...", p. 158.

47. https://todasfunerarias.com.br/tradicoes-e-costumes-no-sepultamento-judaico. 0 artigo esclarece: "A presença de um corpo morto é considerada uma fonte de impureza ritual. Por este motivo, um Cohen não pode permanecer na presença de um cadáver, fazer visitas ou ir a enterro no cemitério, a menos que seja o enterro pelos seus pais. Um Cohen deve ser cercado por um círculo de pessoas de mãos dadas ou um material como uma cerca a sua volta para poder visitar algum túmulo ou permanecer no cemitério".

48. Notícias de Cabo Verde, no 173, de 1/ago/1938.

49. A. Coutinho, "Judeus Marroquinos...", p. 39.

50. A. Coutinho, “Judeus Marroquinos ...", p. 60.

51. Lápide $\mathrm{n}^{\mathrm{o}} 5$ do croqui do Cemitério judaico de Ponta do Sol, gentilmente fornecido pela Cape Verde Jewish Heritage Project.

52. J. Abecassis, Genealogia Hebraica ..., vol. I, p. 460.

53. B.O.C.V. no 21, 1886. Cf. J. Abecassis, Genealogia Hebraica ..., vol. I, p. 461.

54. Croqui gentilmente fornecido pela Cape Verde Jewish Heritage Project.

55. $1^{\circ}$ Anúncio, Praia, 27 de julho de 1894, B.O.C.V. nº 30, 1894.

56. AHN, B.O.C.V. no 2, Ano 1898, Outubro, 20, pp. 217; cit. por C. Correia, Presença de Judeus ..., p. 108.

57. AHN, SGG, cx. no 775 AHN, SGG, cx. no 775 (cit.).

58. Esta conclusão advém do cruzamento das informações fornecidas por M. Serels, Jews of Cape Verde ..., p. 74 e por C. Correia, Presença de Judeus ..., p. 119.

59. B.O.C.V. $\mathrm{n}^{\mathrm{o}} 21,1887$.

60. C. Correia, Presença de Judeus ..., p. 119; http://www.barrosbrito.com/8539.html.

61. AHN, SGG, cx. 775 (cit.).

62. Cf. C. Correia, Presença de Judeus ..., p. 111.

63. Parecer do Doutor Roberto António Martins, AHN, SGG, cx. 775 (cit).

64. B.O.C.V. no 18, 1919; cit. por C. Correia, Presença Judaica ..., 1998, p.70; (1999), 112.

65. C. Correia, Presença de Judeus ..., 1998, p. 119; http://www.barrosbrito.com/8539.html

66. Edição de 30.3.1943, in http://www.barrosbrito.com/8616.html.

67. http://www.barrosbrito.com/8611.html.

68. B.O.C.V. no $14,1909$. 
69. L. Santos, "Wahnon ...".

70. B.O.C.V. $\mathrm{n}^{\mathrm{o}} 11,1868$.

71. B.O.C.V. $\mathrm{n}^{\circ} \mathrm{3}, 1877$.

72. B.O.C.V. $\mathrm{n}^{\mathrm{o}} 41,1884$.

73. B.O.C.V. no $32,(33), 1897$.

74. J. Abecassis, Genealogia Hebraica ..., vol. IV, p. 185.

75. J. Abecassis, Genealogia Hebraica ..., vol. IV, p. 185.

76. B.O.C.V. no 32, (33), 1897.

77. Foi, aliás, onde, a sua filha Sophia Zaffrany foi viver, depois de casar-se por procuração com Abraham Cagi (14.2.1901) por ele já viver em Lourenço Marques, o seu filho Benjamim Zaffrany se casou (Beira), e a sua segunda mulher faleceu (1924). J. Abecassis, Genealogia Hebraica ..., vol. V, p. 186; vol. II, p.508.

78. C. Correia, Presença Judaica ..., 1998, p. 117; http://www.barrosbrito.com/8772.html.

79. http://www.barrosbrito.com/8772.html.

80. Armando Augusto Benoliel de Carvalho "born in Boa Vista in 1901 and died in 1919, a victim of a pneumonia epidemic". Não seria filho do casal? http://www.barrosbrito.com/8773.html\#2; C. Correia, A Presença Judaica ..., 1998, p. 150;

81. Inscrição na lápide do túmulo de Simy Benoliel, http://www.barrosbrito.com/8772.html.

82. Jazigo $\mathrm{n}^{\circ} 2$ no Croqui do Cemitério de Ponta do Sol gentilmente fornecido pela Cape Verde Jewish Heritage Project.

83. CMRG, Atas - 1926- 1934.

84. A. Coutinho, "Judeus Marroquinos...", p. 76.

85. J. Abecassis, Genealogia Hebraica ..., vol. II., pp. 710-711.

86. J. Abecassis, Genealogia Hebraica ..., vol. I, pp. 475-476.

87. J. Abecassis, Genealogia Hebraica ..., vol. III, p. 593.

88. J. Abecassis, Genealogia Hebraica ..., vol. II, p. 139; Lápide no 2 do croqui gentilmente fornecido pela Cape Verde Jewish Heritage Project.

89. B.O.C.V. no 6, 1869; J. Abecassis, Genealogia Hebraica ..., vol. II, p. 139.

90. J. Abecassis, Genealogia Hebraica ..., vol. II, p. 139.

91. A. Coutinho, "Judeus Marroquinos...", p. 38.

92. A. Coutinho, “Judeus Marroquinos...", p. 38 e 75.

93. J. Abecassis, Genealogia Hebraica ..., vol. II, p. 447.

94. A. Coutinho, “Judeus Marroquinos...", p. 75.

95. B.O.C.V. $\mathrm{n}^{\circ} 22,1893$.

96. C. Correia (1998), Judeus de Cabo Verde ...p. 149.

97. B.O.C.V. $\mathrm{n}^{\circ} 8,1891$.

98. A. Coutinho, “Judeus Marroquinos ...", p. 37.

99. «Relação das pessoas que subscreveram para a edificação da igreja matriz da cidade da Praia», B.O.C.V. $\mathrm{n} \times 27,1879$.

100. A. Coutinho, "Judeus Marroquinos ...", p. 47.

101. A. Coutinho, “Judeus Marroquinos ...", pp. 45-46.

102. A. Coutinho, “Judeus Marroquinos ...", p. 61.

103. Idem, Ibidem.

104. Nos livros de pedido de passaporte para trânsito interno entre as ilhas Ângela Benoliel contabilizou " 26 comerciantes judeus, naturais sobretudo de Marrocos e Gibraltar, que entre 1865 e 1881declararam ter residido na cidade da Praia [...]: Isaac Seruya, Jacob Levy, Rafael Benatar, Simão Levy, Marcos Cagi, Simão Benahim, Jaime Azancot, Abraham Benrós, Jacob Levy, Isaac Naury, Moisés benrós, Elias Elasry, Elias Lassarine, Samuel Cohen, Bento Levy, Moisés Naure, David Abecassis, Marcos Bemdaham, Ensim Bouanaz, Simas Booara, Isaac Sabad, Moisés Levy, Marcos Auday, Jacob Seruya, Salomão Anahory, José Seruya e uma mulher, Esther Sabbat”, “Judeus Marroquinos ...”, p. 41. 
105. Benjamim Alves. Hillel Benchimol (Pedra Barro), Isaac Athias (Ribeira da Barca).

106. Moisés Levy.

107. Segundo o "Relatório do serviço da delegação da junta de saúde na ilha de Santo Antão, relativo ao ano de 1873, apresentado pelo dr. Francisco Frederico Hopffer», em 1873 podia-se contabilizar 11 hebreus que há 12 anos residiam na ilha, B.O.C.V. no 35, 1874 .

108. Ibidem.

109. Ibidem.

110. «Junta de Saúde pública - Relatório da delegação de Saúde na ilha de Santo Antão, abrangendo o período que decorre de 15 de maio a 31 de dezembro do ano de 1871, pelo dr. Francisco Frederico Hopffer», B.O.C.V. nº 17, 1872.

111. «Junta de Saúde pública - Relatório do serviço da delegação da junta de saúde na ilha de Santo Antão, relativo ao ano de 1873, apresentado pelo Dr. Francisco Frederico Hopffer», B.O. C.V. no 35,1874 .

112. Ibidem.

113. "quórum necessário para a realização dos serviços religiosos e a recitação de algumas orações, constituído de 10 homens acima de 13 anos", v. R. Heller, Judeus no Eldorado ..., p. 106, nota 161.

114. Idem, ibidem, p. 106.

115. Repartição de Saúde - Relatório, relativo ao ano de 1874, apresentado pelo dr. F.F. Hopffer (ilha de Santo Antão), B.O.C.V. no 34, 1875

116. Ibidem.

117. Relatório do Concelho da Vila da Ribeira Grande da ilha de Santo Antão, João Simões Afra, Administrador do concelho, B.O.C.V. no ${ }^{\circ}$ 42, 1881.

118. Relatório relativo ao triênio findo de 31 de dezembro de 1885, B.O.C.V. no 20,1886 .

119. Ibidem.

120. AHN, TRG, cx. 356, Inventário orfanológico de José Julião Brigham.

121. Ibidem.

122. Ibidem.

123. Auto de Arrematação, in ibidem, p. 81 e sgs.

124. ACRG, Repartição da Fazenda do Concelho da Ribeira Grande, Autos de liquidação de contribuição de registo por óbito de Abraham Julião Brigham, morador que foi da vila da Ponta do Sol, do Concelho da Ribeira Grande, Processo no 367, de 6 de outubro de 1941.

125. ACRG, Repartição da Fazenda do Concelho da Ribeira Grande, Autos de liquidação de contribuição de registo por óbito de Abraham Julião Brigham, morador que foi da vila da Ponta do Sol, do Concelho da Ribeira Grande, Processo no 367, de 6 de outubro de 1941.

126. Ibidem.

127. Ibidem.

128. J. Abecassis, Genealogia Hebraica ..., vol. II, p. 447.

129. ACRG, Repartição da Fazenda do Concelho da Ribeira Grande, Autos de liquidação de contribuição de registo por óbito de Abraham Julião Brigham, morador que foi da vila da Ponta do Sol, do Concelho da Ribeira Grande, Processo no 367, de 6 de outubro de 1941.

130. ACRG, Repartição da Fazenda do Concelho da Ribeira Grande, Autos de liquidação de contribuição de registo por óbito de Abraham Julião Brigham, morador que foi da vila da Ponta do Sol, do Concelho da Ribeira Grande, Processo nº 367, de 6 de outubro de 1941.

131. AHN, TRG (D1), cx. 356, Inventário orfanológico de José Julião Brigham.

132. A. Coutinho, "Judeus Marroquinos...", pp. 76 e 80.

133. "É um documento legal que regista as obrigações financeiras que o marido assume para com a sua mulher, na sequencia do casamento celebrado entre ambos. Em princípio essas obrigações são impostas pela lei religiosa.” I. Steinhardt, “Quetubá ...”, in Dicionário do Judaismo Português, 2009.

134. A. Coutinho, "Judeus Marroquinos... ”, p. 76. 
135. Dos três filhos de Ayres Julião Brigham e Esther Cohen Brigham, Marcos é o único que nascera em Lisboa. Os outros dois, Fortunata Brigham e Abraham Julião Brigham, nasceram já em Cabo Verde. Cf. Serels, Jews of Cape Verde, p. 110.

136. B.O.C.V. no 47, 1912, cit. por C. Correia (1998), p. 72.

137. J. Abecassis, Genealogia Hebraica ..., vol. II, p. 448.

138. J. Abecassis, Genealogia Hebraica ..., vol. II , p. 448.

139. J. Abecassis, Genealogia Hebraica ..., vol . II, p. 448.

140. J. Abecassis, Genealogia Hebraica ..., vol. II, p. 448.

141. https://cip.org.br

142. "Os ashkenazim não têm o costume de dar à criança nome de parentes vivos", https:// cip.org.br

143. Em 1862, o casal já vivia na Ribeira Grande de Santo Antão. Ângela Benoliel Coutinho atesta o fato, ao referir-se a um conflito entre Esther Brigham e Simy Azancot que repartiam, juntamente com os seus maridos a mesma casa na na Ribeira Grande. “Judeus Marroquinos...”, p. 83.

144. AHN \A \SR:D \009, fls. 116, cit. por C. Correia, Presença de Judeus em Cabo Verde p. 27.

145. C. Correia, Presença de Judeus em Cabo Verde, p. 83.

146. B.O.C.V. no 17 (Suplemento), 1867.

147. A. Coutinho, "Judeus Marroquinos... ", p. 80.

148. A. Coutinho, "Judeus Marroquinos... ", p. 76.

149. J. Abecassis, Genealogia Hebraica ..., vol. II, p. 448. Serels confirma os dados de Abecassis, quanto a Marcos Julião Brigham: “(...) he was married in Lisbon to Camilda (Jamilla) Bentubo Wahnon (sic!) who was born in 1876 in Lisbon to Abraham Wahnon." Cf., op. cit., p. 105.

150. C. Correia, Presença de Judeus em Cabo Verde, p. 81.

151. A. Coutinho, "Judeus Marroquinos...", p. 76.

152. B.O.C.V. no 17 (Suplemento), 1867.

153. C. Correia, Presença de Judeus ..., p. 81.

154. AHN, Registo Civil de São Vicente, $\mathrm{cx}, 14$, Assentos de Casamento, freguesia Nossa Senhora da Luz, Peça 81, 10 de janeiro de1894 a 9 de novembro de1895.

155. J. Abecassis, Genealogia Hebraica ..., vol. II, p. 448 e vol. III, p. 594.

156. J. Abecassis, Genealogia Hebraica ..., vol. II, p. 448.

157. J. Abecassis, Genealogia Hebraica ..., vol. III, p. 594.

158. Informação de Luís Almeida Santos.

159. "A circuncisão é realizada através de um "Mohel", homem temente a D'us, cumpridor dos preceitos judaicos e versado na prática da circuncisão, conforme as leis da Torá". https://pt.chabad.org/library/ article_cdo/aid/618835/jewish/Brit-Mil-Circunciso.htm

160. B.O.C.V. $\mathrm{n}^{\mathrm{o}} 11,1868$.

161. M. Serels, Jews of Cape Verde ..., p. 110.

162. José Maria Abecassis, dá como filhos do casal, Abraham, nascido em 1868, em Gibraltar e Raquel, em 1869, em Lisboa (op. cit., vol. I, p. 461). No entanto, não se refere a Bidy, que também nasceu em Lisboa, nem a Rica, também filhas de Marcos e Simy Auday.

163. J. Abecassis, Genealogia Hebraica ..., vol. I, p. 460.

164. Moses Auday, faleceu na cidade da Praia, a 9 de maio de 1886.

165. B.O.C.V. no 37, 38, 1882.

166. J. Abecassis, Genealogia Hebraica ..., vol. II, p. 330.

167. J. Abecassis, Genealogia Hebraica ..., vol. I, p. 460.

168. J. Abecassis, Genealogia Hebraica ..., vol. IV, p. 158.

169. B.O.C.V. no $6,1871$.

170. Croqui gentilmente fornecido pela Cape Verde Jewish Heritage Project.

171. B.O.C.V. no 37, 1871. 
172. Contadoria da Junta da Fazenda Pública da Província de Cabo Verde, B.O.C.V. nº 171, 1847.

173. J. Abecassis, Genealogia Hebraica ..., vol. II, p. 448.

174. J. Abecassis, Genealogia Hebraica ..., vol. IV, p. 158.

175. J. Abecassis, Genealogia Hebraica ..., vol. II, p. 511.

176. B.O.C.V. $\mathrm{n}^{\circ}$ 169, 1855.

177. B.O.C.V. no 9, 1883.

178. J. Abecassis, Genealogia Hebraica ..., vol. II, p. 511.

179. Embora Ângela Benoliel Coutinho afirme ser Simy mulher de James Azancot ("Judeus Marroquinos... ", p. 76), pensamos ser Abrahão o marido, já que James (ou Jayme) Azancot, segundo J.M. Abecassis, era casado com Esther Benafraim (Genealogia Hebraica ..., vol. I, p. 475).

180. J. Abecassis, Genealogia Hebraica ..., vol. II, p. 511.

181. J. Abecassis, Genealogia Hebraica ..., vol. II, p. 506.

182. J. Abecassis, Genealogia Hebraica ..., vol. II, p. 506.

183. J. Abecassis, Genealogia Hebraica ..., vol. II, p. 330.

184. J. Abecassis, Genealogia Hebraica ..., vol. II, p. 331.

185. B.O.C.V. $\mathrm{n}^{\mathrm{o}}$ 11, 1868.

186. B.O.C.V. $\mathrm{n}^{\mathrm{o}} 16$ (Suplemento), 1879.

187. B.O.C.V. no 16 e $36,1879$.

188. J. Abecassis, Genealogia Hebraica ..., vol. I, p. 359

189. J. Abecassis, Genealogia Hebraica ..., vol. IV, p. 157.

190. J. Abecassis, Genealogia Hebraica ..., vol. I, p. 367.

191. J. Abecassis, Genealogia Hebraica ..., vol. I, p. 366.

192. B.O.C.V. no. 19, 1882.

193. J. Abecassis, Genealogia Hebraica ..., vol. I, p. 366.

194. A. Coutinho, “Judeus Marroquinos ...", p. 76.

195. C. Correia, Jews of Cape Verde ..., p. 76.

196. B.O.C.V. no 19, 1882 e B.O.C.V. no $4,1906$.

197. http://www.barrosbrito.com/7046.html.

198. http://www.barrosbrito.com/10102.html.

199. AHN, Registo Civil da Praia, $c x n^{\circ}$ 25, Assentos de Batismos, freguesia de São Nicolau Tolentino, Peça ํำ 10, 30 maio 1879-24 junho 1882.

200. J. Abecassis, Genealogia Hebraica ..., vol. III, pp. 257-258.

201. A. Coutinho, "Judeus Marroquinos...", p. 48.

202. A. Coutinho, "Judeus Marroquinos ..., p. 40.

203. A. Coutinho, “Judeus Marroquinos ...", p. 13

204. Ignes de Barros Monteiro e Paula da Conceição Monteiro

205. J. Abecassis, Genealogia Hebraica ..., vol. I, p. 369.

206. AHN, Registo Civil da Praia, $c x n^{\circ}$ 63, Assentos de Casamentos, freguesia de Santo Amaro Abade, Peça oㅜ 1, Fevereiro a Junho de 1888.

207. O irmão mais velho de David, Naturino de Melo Alves é quem faz o registo em 26 de dezembro de 1913. AHN, Tribunal da Praia, cx 297, Inventário Orfanológico de Benjamim Alves (1918).

208. AHN, Tribunal da Praia, cx 297, Inventário Orfanológico de Benjamim Alves (1918).

209. AHN, Tribunal da Praia, cx 297, Inventário Orfanológico de Benjamim Alves (1918).

210. C. Correia, Judeus de Cabo Verde, p. 103.

211. C. Correia, Judeus de Cabo Verde, p. 103; http://www.barrosbrito.com/10392.html

212. C. Correia, Judeus de Cabo Verde, p. 124; http://www.barrosbrito.com/15292.html

213. http://www.barrosbrito.com/15292.html; O Independente, no 28, 7 de fevereiro,1913.

214. http://www.barrosbrito.com/15292.html; https://www.familysearch.org/ark:/ 61903/3:1:3Q9M-C95G-BFFG?cc=2246703 
215. J. Abecassis, Genealogia Hebraica ...,vol. IV, p. 162; http://www.barrosbrito.com/10390.html. 216. Informação de Luis Almeida Santos. Tiveram uma filha: Arleth Wahnon Benoliel de Carvalho. Cf. http://www.barrosbrito.com/8773.html.

217. http://www.barrosbrito.com/9878.html.

218. A Liberdade, $\mathrm{n}^{\circ}$ 4, domingo, 20 de abril de 1902, Suplemento $\mathrm{n}^{\circ} 40$.

219. Aurélio Martins é o autor da notícia, Ibidem.

220. http://www.barrosbrito.com/15839.html.

221. Informação prestada por Luis de Almeida Santos.

222. http://www.barrosbrito.com/9879.html.

223. Informação prestada por Luis de Almeida Santos.

224. http://www.barrosbrito.com/8893.html\#1.

225. http://www.barrosbrito.com/12399.html.

226. A. Coutinho, “Judeus Marroquinos...", p. 37.

227. http://www.barrosbrito.com/8893.html; http://www.barrosbrito.com/8894.html.

228. C. Correia, Judeus de Cabo Verde..., p. 83.

229. http://www.barrosbrito.com/8893.html; http://www.barrosbrito.com/8894.html.

230. J. Abecassis, Genealogia Hebraica ..., vol. I, pp. 359-360.

231. J. Abecassis, Genealogia Hebraica ..., vol. I, p. 360.

232. Ângela Benoliel cita Elias Anahory como um dos "investidores" do Mindelo de finais do séc. XIX e inícios do XX, “Judeus Marroquinos...", p. 61.

233. B.O.C.V. $\mathrm{n}^{\circ} 20,1864$.

234. J. Abecassis, Genealogia Hebraica ..., vol. I, p. 363.

235. J. Abecassis, Genealogia Hebraica ..., vol. I, p. 364.

236. J. Abecassis, Genealogia Hebraica ..., vol. I, p. 363.

237. J. Abecassis, Genealogia Hebraica ..., vol. I, p. 364.

238. J. Abecassis, Genealogia Hebraica ..., vol. I, p. 375.

239. José Maria Abecassis esclarece: “Quando Simão Anahory tinha 52 anos esteve gravemente doente, em perigo de vida, pelo que, a 5.12.1899, pelas 8h da manhã na Sinagoga «Es-Haim $2^{\circ} »$, sita no Beco dos Apóstolos, $6^{-}-2^{\circ}$, em Lisboa, se celebraram preces suplicantes ao Altíssimo pelo seu restabelecimento. E nesse ato solene, e segundo os preceitos do rito hebrauico, ficou-se chamando Raphael Simão Anahory, o que teve lugar com a anuência da respectiva família", Genealogia Hebraica ..., vol. I, p.368.

240. http://www.barrosbrito.com/12396.html\#1.

241. J. Abecassis, Genealogia Hebraica ..., vol. I, pp. 369-370.

242. J. Abecassis, idem. Ângela Benoliel Coutinho faz alusão a este fato, in "Judeus Marroquinos...", p. 86.

243. J. Abecassis, Genealogia Hebraica ..., vol. I, pp. 369-370.

244. J. Abecassis, Genealogia Hebraica ..., vol. I, p. 370.

245. B.O.C.V. $n^{\circ}$ 35, 1876 e B.O.C.V. $n^{\circ}$ 35, 1877 (Leão); B.O.C.V. no 36, 1879 (Joseph e Simy); B.O.C.V. nº 36, 1880 (Joseph e Simy); B.O.C.V. no 35, 1884 (David); B.O.C.V. no 34, 1885 (David e Salomão).

246. B.O.C.V. $\mathrm{n}^{\mathrm{o}}$ 41, 1876 (Abrahão Augusto Esaguy), B.O.C.V. $\mathrm{n}^{\mathrm{o}}$ 40, 1877 (Joaquim Augusto Esaguy); B.O.C.V. no 37, 1883 (Isaac Augusto Esaguy). Sublinhe-se a excelência de Isaac Augusto Esaguy, nos estudos do primeiro grau, o que lhe valeu um prémio e uma homenagem concedida "aos alunos que mais se distinguiram" no ano de 1883, pela Camara Municipal de São Nicolau, B.O.C.V. no 47, 1883.

247. Isaac Augusto Ezaguy foi aprovado nemine tanto no português como no de francês, como aluno externo, no $2^{\circ}$ ano, Movimento literário dos alunos do Seminário liceu de Cabo Verde do ano letivo de 1 de agosto de 1886 a 31 de julho de 1887, in B.O.C.V. oㅜ 37, 1887.

248. J. Abecassis, Genealogia Hebraica ..., vol. II, p. 710 e sgs.

249. Segundo João Manuel Nobre de Oliveira, a escola de educação para meninas fundada, em 1844, por Mme Macaulay, na ilha da Boa Vista, funcionou no Rabil até 1879 sendo, a partir desta 
data, transferida para a vila de Sal Rei, in “A Imprensa Cabo-Verdiana 1820-1975 ", Fundação Macau, Direção dos Serviços de Educação e Juventude, 1998, p. 56.

250. Simy foi uma aluna com 20 valores mas tanto ela como Alegria Bohana ficaram entre as três estudantes meninas "que mais se distinguiram, no ano lectivo de 1889-1880", B.O.C.V. no 36, 1880 .

251. B.O.C.V. $\mathrm{n}^{\mathrm{o}} 17,1879$.

252. B.O.C.V. $\mathrm{n}^{\circ} 36,1879$. Ao invés de Elisa, seria Ernestina?

253. http://www.barrosbrito.com/10388.html.

254. http://www.barrosbrito.com/10957.html.

255. http://www.barrosbrito.com/8665.html; AHN, Registo Civil de São Vicente, cx 34, Assentos de Batismos, freguesia de Santa Isabel da ilha da da Boa Vista, Peça 6, 18 de dezembro de 1882 a 24 de dezembro de1883.

256. http://www.barrosbrito.com/10958.html\#1; AHN, Registo Civil de São Vicente, cx 34, Assentos de Batismos, freguesia de Santa Isabel da ilha da Boa Vista, Peça 2, 9 de abril a 9 de dezembro 1877.

257. AHN, Registo Civil de São Vicente, cx 34, Assentos de Batismos, freguesia de Santa Isabel da ilha da da Boa Vista, Peça 5, 25 de fevereiro de 1881 a 27 de novembro de 1882.

258. http://www.barrosbrito.com/15157.html; AHN, Registo Civil de São Vicente, cx 34, freguesia de Santa Isabel da ilha da da BoaVista, Peça 8, 01 de janeiro de 1887 a 18 de maio de 1889.

259. http://www.barrosbrito.com/15158.html; AHN, Registo Civil de S. Vicente, cx 34, freguesia de Santa Isabel da ilha da Boa Vista, Peça 8, 01 de janeiro de 1887 a 18 de maio de 1889.

260. B.O.C.V. $\mathrm{n}^{\mathrm{0}} 27,1879$.

261. Relação das pessoas que na ilha de São Vicente, subscreveram para a construção de uma igreja na cidade da Praia, 7 de abril de 1879, B.O. 16 (Suplemento), 1879.

262. «Junta de Saúde pública - Relatório do serviço da delegação da junta de saúde na ilha de Santo Antão, relativo ao ano de 1873, apresentado pelo Dr. Francisco Frederico Hopffer», B.O. C.V. nº 35, 1874 .

263. Leão Benoliel morreu aos 46 anos, acidentalmente em Lisboa, no dia 5 de outubro de 1910, no estado de solteiro, B.O.C.V. no $^{\circ} 49,1910$.

264. C. Correia, Judeus de Cabo Verde ..., p. 95.

265. http://www.barrosbrito.com/15260.html\#3; AHN, Registo Civil de São Vicente, cx. 58, Assentos de Casamentos, freguesia de Santa Isabel da Ilha da Boa Vista, Peça 33,18 de janeiro a 28 de julho de 1900.

266. C. Correia, Judeus de Cabo Verde ..., p. 163; Inventário do Património Cultural Imóvel do Instituto do Património Cultural, Cabo Verde; B.O.C.V. no 48, 1911.

267. B.O.C.V. $\mathrm{n}^{\circ} 48,1911$.

268. http://www.barrosbrito.com/8773.html.

269. C. Correia, Judeus de Cabo Verde ..., p. 95; http://www.barrosbrito.com/8539.html\#1; AHN, Registo Civil de São Vicente, cx. 58, Assentos de Casamentos, freguesia de Santa Isabel da Ilha da Boa Vista, Peça 31, 3 de janeiro a 21 de dezembro de 1898.

270. B.O.C.V. $\mathrm{n}^{\circ}$ 50, 1893.

271. C. Correia, Judeus de Cabo Verde ...", p. 124.

272. A. Coutinho, "Judeus Marroquinos...", p. 78.

273. C. Correia, Judeus de Cabo Verde ..., p. 72

274. B.O.C.V. $\mathrm{n}^{\circ}$ 12,1912.

275. ACRG, Autos de Liquidação de contribuição de Registo por título gratuito por óbito de Gertrudes Felicidade Silva - Vila da Ribeira Grande (1829-1933).

276. AHN, Registo Civil de Santo Antão, cx. 29, Assentos de Óbitos da freguesia de Nossa Senhora do Rosário, 01 jan-31 dez 1883, no 136.

277. ACRG, Administração do Concelho da Ribeira Grande, Registo de Bilhetes de Identidade (diploma Leg $^{\circ} \mathrm{n}^{\circ} 197$ de 8 - 5 -1929). 
278. ACRG, Autos de Liquidação de contribuição de Registo por título gratuito por óbito de Gertrudes Felicidade Silva, Vila da Ribeira Grande (1829-1933).

279. AHN, Registo Civil da Praia, cx. 63, Assentos de Casamentos, freguesia de Santo Amaro Abade, Peça 1, fevereiro a junho de 1888.

280. B.O.C.V. no 33,1917; Cláudia Correia 1998, p. 36.

281. http://www.barrosbrito.com/7046.html.

282. J. Abecassis, Genealogia Hebraica ..., vol. IV, p. 44.

283. http://www.barrosbrito.com/13744.html.

284. C. Correia, Judeus de Cabo Verde ..., p. 107.

285. David Azancot e Maria da Conceição Pereira são pais de Pedro David Azancot, nascido em São Nicolau. Cf. http://www.barrosbrito.com/15400.html; https://www.familysearch.org/ark:/ 61903/3:1:3QS7-L974-DHC3,

AHN, Bilhetes de identidade, Praia, ACP-Lv 357, 1945-1950.

286. J. Abecassis, Judeus de Cabo Verde ..., vol. II, p. 330.

287. AHN, Registo Civil de São Vicente, cx.14, Assentos de Casamento, freguesia Nossa Senhora da Luz, Peça 81, 10 de janeiro de 1894 a 9 de novembro de 1895.

288. AHN, Registo Civil de São Nicolau, cx. 1, Assentos de Batismos, freguesia de Nossa Senhora do Rosário, Peça 106 de novembro de1842 a 03 de agosto de 1852; Peça 2, 11de Setembro de1852 a 20 de março de1864; Peça 310 de abril de1864 a 18 de julho de1866; AHN, Registo Civil de São Nicolau, cx. 9, Óbitos Nossa Senhora do Rosário, Peça 46, 13 de julho de 1855 a 26 de maio de 1865.

289. Ângela Benoliel Coutinho refere-se às circunstâncias em que o direito talmúdico permite a bigamia "por parte do marido", " sendo a esposa considerada estéril; para assegurar o exercício do lévirat, que consiste na obrigação por lei de o irmão de um falecido casar-se com a cunhada viúva que não tivesse filhos, de modo a garantir-lhe uma posteridade; quando o marido, encontrando-se longe da esposa, não podia juntar-se a ela por razões de força maior; por fim, quando a esposa estava doente e impossibilitada de manter relações conjugais íntimas", "Judeus Marroquinos.... ", p. 23.

290. José Maria Abecassis, op. cit., vol. IV, p. 157.

291. Ibidem.

292. Ibidem.

293. José Maria Abecassis, op. cit., vol. IV, p. 158.

294. Luis de Almeida Santos.

295. http://www.barrosbrito.com/5444.html.

296. ACRG, Atas da Câmara da Ribeira Grande 1926-1934; ACRG, Administração do Concelho da Ribeira Grande - Registo de Bilhetes de Identidade (diploma Legoㅡํㅡ 197 de 8 - 5 -1929; Jornal); Notícias de

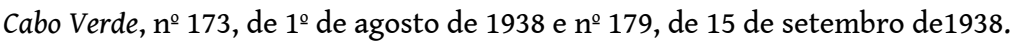

297. José Maria Abecassis, op. cit., vol. IV, p. 157.

298. Notícias de Cabo Verde, $\mathrm{n}^{\circ}$ 179, de 15 de setembro de 1938.

299. C. Correia, Judeus de Cabo Verde ...", p. 123.

300. AHN, Registo Civil da Praia, cx. 25, Assentos de Batismos, freguesia de S. Nicolau Tolentino, Peça 10, 30 de maio de 1879 a 24 de junho de 1882.

301. http://www.barrosbrito.com/14273.html; AHN, Registos Civis da Praia, cx. 63, Assentos de Casamentos, freguesia de Santo Amaro Abade, Peça 1, fevereiro a junho de 1888.

302. AHN, Assentos de Batismo..., cópia gentilmente cedida por Flávio Delgado.

303. AHN, Tribunal da Praia, cx. 297, Inventário Orfanológico de Benjamim Alves (1918).

304. Benjamim Alves e Emília de Melo haviam-se divorciado seis meses antes de ele vir a falecer. A sentença tinha sido dada "em 1 de julho do corrente e transitava em julgado mas sem que tivesse ainda sido requerido o competente inventário para divisão dos bens do casal". AHN, Tribunal da Praia, cx. 297, Inventário Orfanológico de Benjamim Alves (1918).

305. O reconhecimento dos filhos ilegítimos era feito, mediante uma nota secreta "nos termos do $\operatorname{art}^{\circ} 289$ do regulamento do Registo Civil". No caso em concreto, Juvêncio, nascido antes do casamento 
de Benjamim, era o único que não era reconhecido mas, mesmo ele, por ter provado a filiação, foi também considerado herdeiro. AHN, Tribunal da Praia, cx. 297, Inventário Orfanológico de Benjamim Alves (1918).

306. AHN, Tribunal da Praia, cx 297, Inventário Orfanológico de Benjamim Alves (1918).

307. Data de fins de 1845, a primeira referência que encontramos a respeito de Joseph Abitbol, na ilha de São Nicolau, B.O.C.V. nº 130, 1846.

308. A. Coutinho, "Judeus Marroquinos....", p. 56.

309. "Relação dos europeus falecidos nesta província, e cujas comunicações foram recebidas nesta Secretaria Geral, desde 11 de Setembro do ano passado [1880]", in B.O.C.V. no 22, 1881.

310. AHN, Registo Civil de São Nicolau, cx 1, Assentos de Batismos, freguesia de Nossa Senhora do Rosário, Peça 1, 06 de novembro de1842 a 03 de agosto de 1852; Peça 2, 11 de setembro de1852 a 20 de março de1864; Peça 3, 10 de abril de 1864 a18 de julho de1866.

311. Em vários assentos de baptismo em que ela serve de madrinha, Maria das Neves Spencer é sempre referida como "solteira". Cf. Ibidem.

312. Ibidem.

313. Ibidem.

314. C. Correia, Judeus de Cabo Verde ..., p.102. A autora engana-se, entretanto, no nome de uma das filhas. Trata-se de Francisca, ao invés de Maria das Neves d'oliveira que é sua neta, filha de Júlio.

315. "Relação do movimento literário dos alunos do seminário-liceu de Cabo Verde, no ano lectivo de 1 de julho de 1876 a 30 de junho de 1877", in B.O.C.V. no ${ }^{\circ} 40,1877$.

316. "Relação dos europeus falecidos nesta província, e cujas comunicações foram recebidas nesta Secretaria Geral, desde 11 de Setembro do ano passado [1880]”, in B.O.C.V. no 22, 1881 .

317. B.O.C.V. $\mathrm{n}^{\mathrm{0}} 27,1874$.

318. "Relação dos europeus falecidos nesta província, e cujas comunicações foram recebidas nesta Secretaria-Geral, desde 11 de Setembro do ano passado [1880] ", in B.O.C.V. ํำ 22, 1881.

319. João Nobre de Oliveira, (2010), p. 102.

320. Mordechai Auday ocupa o túmulo no 5 no Cemitério judaico de Ponta do Sol. V. Croqui gentilmente fornecido pela Cape Verde Jewish Heritage Project. Cf. J. Abecassis, Genealogia Hebraica ..., vol. I., p. 460.

321. Cf. C. Correia, Judeus de Cabo Verde ..., p.83, e A. Coutinho, "Judeus Marroquinos...", p. 46.

322. J. Abecassis, Genealogia Hebraica ..., vol. IV., p. 157.

323. Cf. J. Abecassis, Genealogia Hebraica ..., vol. II., p. 447.

324. B.O.C.V. $n^{\circ}=30,1872$.

325. AHN, Tribunal da Praia cx 342, Autos de Inventário de menores em que é inventariado Hillel Benchimol e inventariante Aureliano Lopes do Livramento, 18 de julho de 1907. Reginaldo Jonas Heller, citando Wolff, Egon e Frieda (Crônicas ...), reproduz um caso similar acontecido com Samuel Levy, "comerciante e senhor de escravos em Cachoeiro de Itapemirim, no Brasil, desde 1856, [que] afirmou no seu testamento, feito em 1897, que "professo a religião judaica em cuja fé tenho vivido. Sou solteiro e não tenho herdeiros necessários... [mas] Reconheço como meus filhos, como nascidos fossem de legítimo matrimónio, os seguintes: Alfredo Levy, filho de Deolinda e Carlos Levy, filho de Jacinta", Judeus no Eldorado ..., p. 148.

326. Ibidem.

327. Ibidem.

328. http://www.barrosbrito.com/5946.html.

329. AHN, Tribunal da Praia, $\mathrm{cx} \mathrm{n}^{\circ} \mathrm{342}$, Autos de Inventário de menores em que é inventariado Hillel Benchimol e inventariante Aureliano Lopes do Livramento, 18 de julho de 1907.

330. AHN, Tribunal da Praia, cx 297, Inventário Orfanológico de Benjamim Alves (1918).

331. AHN, TRG, cx. 356, Inventário orfanológico de José Julião Brigham.

332. B.O.C.V. $\mathrm{n}^{\circ} 41,1866$. 
333. B.O.C.V. no $46,1867$.

334. A. Coutinho, “Judeus Marroquinos...", p. 63.

335. http://www.barrosbrito.com/13510.html.

336. A. Coutinho, “Judeus Marroquinos...", p. 78.

337. C. Correia, Judeus de Cabo Verde ..., p. 177.

338. Citado por J. Oliveira, “A presença judaica ...”, p. 101.

339. A. Coutinho, “Judeus Marroquinos...", p. 1.

340. J. Abecassis, Genealogia Hebraica ..., vol. II., p. 711.

341. J. Abecassis, Genealogia Hebraica ..., vol. II., p. 723.

342. A. Coutinho, “Judeus Marroquinos...", p. 58.

343. B.O.C.V. $\mathrm{n}^{\mathrm{o}} 17,1881$.

344. J. Abecassis, Genealogia Hebraica ..., vol. II., pp. 710-711.

345. A Coutinho, “Judeus Marroquinos...", p. 63.

346. AHN, Assentos de Batismo.... cópia gentilmente cedida por Flávio Delgado.

347. A. Coutinho, “Judeus Marroquinos...", p. 39.

348. Idem, ibidem.

349. A. Coutinho, “Judeus Marroquinos...", p. 81, citanto S. Benchimol, Eretz Amazónia ..., p.97.

350. A. Coutinho, “Judeus Marroquinos...", p. 82.

351. J. Abecassis, Genealogia Hebraica ..., vol. I, pp. 475-476.

352. A. Coutinho, “Judeus Marroquinos...", p. 37.

353. «Junta de Saúde Pública - Relatório do serviço da delegação da junta de saúde na ilha de Santo Antão, relativo ao ano de 1873, apresentado pelo Dr. Francisco Frederico Hopffer», B.O. C.V. no 35,1874 .

354. Ibidem.

355. Repartição de Saúde - Relatório, relativo ao ano de 1874, apresentado pelo dr. F.F. Hopffer (ilha de Santo Antão), B.O.C.V. no 34,1875

356. Relatório do Concelho da Vila da Ribeira Grande da ilha de Santo Antão, João Simões Afra, Administrador do concelho, B.O.C.V. $\mathrm{n}^{\circ} \mathrm{42}, 1881$.

\section{RESUMOS}

Este artigo tem como objectivo estudar as práticas de preservação da memória judaica em Cabo Verde, através da releitura do património tumular hoje existente, resultante da imigração de hebreus marroquinos e gibraltinos, ocorrida no século XIX. A nossa démarche, palmilhada em contramão, consiste em ir da morte à vida, dos túmulos à cultura mortuária, dos testamentos à biografia dos testadores.

The objective of this article is to study the practices of the jewish's memory, preservation in Cabo Verde, through the re-lecture of the tomb stones patrimony still existant today, as a result of the hebrews morrocan's and gibraltan's immigration, that took place in the XIX century. Our demarche consists in going from death to life, from the tombe stones to mortuary culture, from the wills to the biography of testators. 
ÍNDICE

Keywords: Cabo Verde, jewish diaspora, tomb stones, cemiteries, families

Financiamento http://dx.doi.org/10.13039/501100005635

Palavras-chave: Cabo Verde, diáspora judaica, túmulos, cemitérios, famílias

\section{AUTOR}

\section{ZELINDA COHEN}

Doutoranda em História na FLUL; Instituto do Património Cultural - Cabo Verde cohenzelinda2021@gmail.com 